The Uncertainty of Certainty in Aboriginal Land Rights:

Is there an alternative?

\author{
by \\ Kelly Kutchaw-Polak, B.A. (Honours)
}

\begin{abstract}
A Thesis Submitted to
the Faculty of Graduate Studies and Research

in partial fulfillment of

the requirements for the degree of
\end{abstract}

Master of Arts

Department of Law

Carleton University

Ottawa, Ontario

May 15, 2007

Copyright

2007, Kelly Kutchaw-Polak 


$\begin{array}{ll}\begin{array}{l}\text { Library and } \\ \text { Archives Canada }\end{array} & \begin{array}{l}\text { Bibliothèque et } \\ \text { Archives Canada }\end{array} \\ \begin{array}{l}\text { Published Heritage } \\ \text { Branch }\end{array} & \begin{array}{l}\text { Direction du } \\ \text { Patrimoine de l'édition }\end{array} \\ \begin{array}{l}\text { 395 Wellington Street } \\ \text { Ottawa ON K1A ON4 } \\ \text { Canada }\end{array} & \begin{array}{l}\text { 395, rue Wellington } \\ \text { Ottawa ON K1A 0N4 } \\ \text { Canada }\end{array}\end{array}$

Your file Votre référence ISBN: 978-0-494-26953-4 Ourfile Notre référence ISBN: 978-0-494-26953-4

NOTICE:

The author has granted a nonexclusive license allowing Library and Archives Canada to reproduce, publish, archive, preserve, conserve, communicate to the public by telecommunication or on the Internet, loan, distribute and sell theses worldwide, for commercial or noncommercial purposes, in microform, paper, electronic and/or any other formats.

The author retains copyright ownership and moral rights in this thesis. Neither the thesis nor substantial extracts from it may be printed or otherwise reproduced without the author's permission.
AVIS:

L'auteur a accordé une licence non exclusive permettant à la Bibliothèque et Archives Canada de reproduire, publier, archiver, sauvegarder, conserver, transmettre au public par télécommunication ou par l'Internet, prêter, distribuer et vendre des thèses partout dans le monde, à des fins commerciales ou autres, sur support microforme, papier, électronique et/ou autres formats.

L'auteur conserve la propriété du droit d'auteur et des droits moraux qui protège cette thèse. $\mathrm{Ni}$ la thèse ni des extraits substantiels de celle-ci ne doivent être imprimés ou autrement reproduits sans son autorisation.
In compliance with the Canadian

Privacy Act some supporting forms may have been removed from this thesis.

While these forms may be included in the document page count, their removal does not represent any loss of content from the thesis.
Conformément à la loi canadienne sur la protection de la vie privée, quelques formulaires secondaires ont été enlevés de cette thèse.

Bien que ces formulaires aient inclus dans la pagination, il n'y aura aucun contenu manquant.

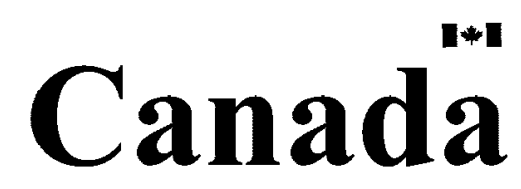




\begin{abstract}
This thesis is an examination of certainty models used in the settlement of modern-day treaties negotiated between Aboriginal groups, the Government of Canada and Provinces and Territories. It assesses the extent to which an alternative model could be developed to achieve certainty that recognizes the interests of all parties, without Aboriginal groups having to cede, release, surrender, extinguish or modify any rights that exist outside the treaty.

Based on multi-lines of evidence, this thesis purports that in order to satisfy the interests of all parties, a reconciliation model of certainty which incorporates essential elements such as mutual respect, trust, accommodation, consultation, recognition of Aboriginal rights and title, fulfilment of obligations, etc., should be adopted or at a minimum serious consideration should be given to the key elements to further the achievement of certainty.
\end{abstract}




\section{ACKNOWLEDGEMENTS}

As I reflect back on four years worth of research and writing, I realize that the completion of this thesis would not have been possible without a lot of love, encouragement and guidance. To Davor, Alex and Andi, my loving family and anchor, I thank you for your unwavering support and confidence in my abilities, but most of all for your love and patience through what must have seemed like endless hours of 'just one more page'.

To my family, friends and colleagues - at last it is over! I thank each and every one of you for putting up with long discussions and rants in trying to finish this thesis. It was amazing how many of you kept a smile on your face as I attempted to articulate what certainty was about...that is truly a sign of a real friend. To those of you who took on the added task of being proof reader, yes, someday I will learn where the comma goes!

I would be committing a grave error if I did not acknowledge those managers and directors at both the Department of Justice and Indian and Northern Affairs Canada for the support and time to attend classes, complete research and conduct interviews. Your commitment to helping me pursue this endeavour will never be forgotten.

To those key individuals who took time out of their very busy days and granted me an interview, I am eternally grateful. Your candour in answering the questions and sharing individual stories and experiences was of extreme value in helping me tackle this issue. I was truly impressed by the level of compassion that was expressed by each and every one of you.

Last but certainly not least, I would like to thank Peter Swan, my thesis supervisor and the first professor I had at Carleton University. It has definitely been a great run Peter but we both knew I had to graduate before my children started university! 


\section{NOTICE TO READER}

During the writing and at the time of completion of this thesis, both the Indian and Northern Affairs Canada and the Department of Justice, Government of Canada, employed the author.

The author affirms that this thesis is solely a work of individual research. It has not been reviewed or approved by Indian and Northern Affairs Canada or the Department of Justice.

Except where otherwise noted, the analysis, recommendations and conclusions presented in thesis are not intended to be statements of departmental policy; neither do they represent the position of the Government of Canada with respect to Aboriginal persons and the issue of certainty. 
Acronyms

Chapter 1

$\begin{array}{llr}\text { A. Introduction } & 1 \\ \text { B. Conceptual Framework } & 5 \\ \text { C. Methodology } & 8\end{array}$

Chapter 2 - The Early Foundations of Certainty 12

A. Aboriginal Title and the Importance of the Land 14

$\begin{array}{ll}\text { B. The Conception of Certainty } & 18\end{array}$

C. Legal Battles Surrounding Aboriginal Title \& European Discovery 27

D. Summary of the Early Frameworks for Claims and Certainty 33

Chapter 3 - Modern Day Treaties and Certainty 37

A. The Birth of Modern-day Treaties 39

B. Aboriginal Rights and the Constitution 44

C. Changes to the Comprehensive Claims Policy 46

$\begin{array}{ll}\text { D. Legal Battles } & 48\end{array}$

E. Summary of Modern-day Treaties and Certainty 56

Chapter 4 - Writing the path to Certainty: Alternative Models 59

A. Commissions, Fact Finders and Task Forces 61

B. Co-existence and Mutual Assurances $\quad 67$

$\begin{array}{ll}\text { C. Summary } & 80\end{array}$

Chapter 5-The Evolution of Certainty $\quad 81$

A. Case Study 1 - The James Bay and Northern Quebec Agreement 81

B. Case Study 2 - The Nisga'a Final Agreement 87

C. Case Study 3 - The Tlicho Final Agreement 93 
TABLE OF CONTENT vi

D. Release 98

$\begin{array}{lll}\text { E. Summary } & 100\end{array}$

Chapter 6-Reconciling the Uncertainty 102

$\begin{array}{lll}\text { A. Context } & 103\end{array}$

B. The Reconciliation Model 106

C. A Home for Certainty 110

$\begin{array}{ll}\text { D. Summary } & 121\end{array}$

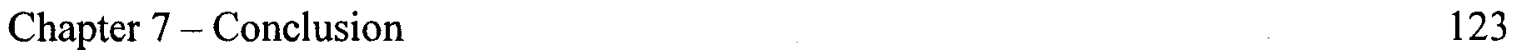

$\begin{array}{ll}\text { References } & 129\end{array}$

Annexes

A. Introductory Letter 142

B. Interview Guidelines 145

$\begin{array}{ll}\text { C. Questionnaire } & 148\end{array}$

D. Consent Form 152

E. Agreement Form 154

Appendices

1 Terms 157

2 Certainty and Extinguishment Provisions in Comprehensive Land Claim 161 Agreements

3 Research Questions and Methodology 166

$\begin{array}{lll}4 . & \text { Acceptance of Claims } & 167\end{array}$

5 Comparison of Hamilton's Model against the James Bay, Nisga'a \& Tlicho 169 Final Agreements

6 Comparison of Hamilton's Model against Reconciliation Model of 174 Certainty 


\begin{tabular}{|l|l|}
\hline AFN & Assembly of First Nations \\
\hline BC & British Columbia \\
\hline BNA ACT & British North American Act \\
\hline CLCP & Comprehensive Land Claims Policy \\
\hline CRIC & Centre of Research and Information on Canada \\
\hline DFO & Department of Fisheries and Oceans \\
\hline DOJ & Department of Justice \\
\hline GNWT & Government of the Northwest Territories \\
\hline IMA & Interim Measures Agreement \\
\hline INAC & Indian and Northern Affairs Canada \\
\hline JBNQA & James Bay and Northern Quebec Agreement \\
\hline JCPC & Judicial Committee of the Privy Council \\
\hline NIB & National Indian Brotherhood \\
\hline NFA & Nisga'a Final Agreement \\
\hline NPI & Negotiation Preparedness Initiative \\
\hline OAG & Office of the Auditor General \\
\hline ONC & Office of Native Claims \\
\hline RCAP & Royal Commission on Aboriginal Peoples \\
\hline RPA & Royal Proclamation Act \\
\hline PCO & Privy Council Office \\
\hline SCC & Supreme Court of Canada \\
\hline TRM & Treaty Related Measures \\
\hline UBIC & Union of British Columbia of Indian Chiefs \\
\hline
\end{tabular}




\section{CHAPTER 1}

"Our people have always understood that we must be able to continue to live our lives in accordance with our culture and spirituality. Our elders have taught us that this spirit and intent of our treaty must last as long as the rivers flow and the sun shines. We must wait however long it takes for non-Aboriginal people to understand and respect our way of life. This will be the respect that the treaty relationship between us calls for."

Josephine Sandy

Ojibwa Tribal Family Service

\section{A. Introduction}

Although great strides have been made by Aboriginal people in Canada to have their rights recognized and affirmed, there still remains much ambiguity in relation to the scope and nature of these rights. ${ }^{2}$ One of the underlying sources of ambiguity focuses on the issue of certainty ${ }^{3}$ in relation to Aboriginal rights and title manifested within historical and 'modern-day treaties' ${ }^{\text {' }}$. While certainty in and of itself is not a complicated concept ${ }^{5}$, applied within the context of settling modern-day treaties, it is open to widely different interpretations by governments, Aboriginal groups, third parties, and the Canadian legal system. ${ }^{6}$

Under the methods that currently exist, certainty is meant to put an end to

1 Canada, Royal Commission on Aboriginal Peoples, Vol. 2, Restructuring the Relationship, (1996) online: Indian and Northern Affairs Canada $<$ http://www.ainc-inac.gc.ca/ch/rcap/sg/sgmm e.html $>$ (last modified: 24 December 2003) at 1. [hereinafter RCAP].

2 In 1982, section 35 of the Constitution Act recognized and affirmed existing treaty rights. Constitution Act 1982 (UK), 1982, c.11, s.35. However, since 1973, Aboriginal groups have successfully used the Canadian legal system to advance Aboriginal rights and title. While the courts have set out guidelines and tests to determine whether Aboriginal rights may exist, the nature and scope of Aboriginal rights and title have not been concisely defined. For examples, see Calder v. Attorney General of British Columbia, [1973] 3 S.C.R. 313, R. v. Sparrow, [1990] 1 S.C.R. 1075, Delgamuukw v. The Queen in Right of British Columbia, [1997] 3 S.C.R. 1010, and R.v. Marshall, [1993] 3 S.C.R. 533.

In its simplest form certainty is used to clarify each party's position and rights in relation to the land base and rights being claimed. Certainty of land tenure is meant to bring about economic development, since without it, third parties, such as industry, are unclear as to who owns the land and/or resources and/or who should be approached and compensated to exploit them. Please see Appendix 1 for other Terms that will be used throughout this thesis.

$4 \quad$ Modern-day treaties/agreements or comprehensive land claims are defined as those treaties negotiated after the introduction of 1979 Comprehensive Land Policy. The term modern-day treaty is used to distinguish between treaties negotiated in a modern-day context as opposed to historical treaties prior to 1975. Please see Appendix 1 for other Terms that will be used throughout this thesis.

5 Indian Affairs and Northern Development, Canada and Aboriginal Peoples: A New Partnership, by Hon. A.C Hamilton (Ottawa: Minister of Public Works and Government Services Canada, 1995) at 35. [hereinafter Hamilton Report].

Department of Indian Affairs and Northern Development, (1993) Federal Policy for the Settlement of Native Claims, Minister of Indian Affairs and Northern Development, Ottawa, at I. 
ambivalence and to clearly and concisely define rights that are contained in a treaty. Existing as both a legal and as a political juxtaposition, certainty largely subsists as a diverse concept within the boundaries of the law and politics. In the legal sense, certainty is viewed as a process. The rudimentary foundation of signing a treaty can be interpreted to mean that Aboriginal beneficiaries exchange undefined rights for a package of defined rights, which are then detailed in a final legally binding agreement. Subsequently, rights not set out in the agreement are ceded, released, surrendered and/or modified, thus seemingly creating certainty for all parties. This is done through the inclusion of clauses requiring Aboriginal people to release certain rights and in the end "there will be no Aboriginal title or rights which survive their exclusions from the written Agreement"? As such, ceding, releasing, and surrendering, as noted in the clauses of historical and modern-day treaties, is a process by which an Aboriginal group gives up, gives away and/or formally relinquishes their rights and/or title with no expectations of ever recovering that what was given up. ${ }^{8}$

In the political realm, certainty can be viewed as an objective that can be used to measure the success/benefit gained by parties through the settling of land claim agreements. For example, the Comprehensive Land Claims Policy "aims to resolve claims to Aboriginal title in areas of Canada that have not been addressed by treaty or other legal means, with negotiations having two objectives: establish certainty of title to lands and resources; and enhance economic development and socio-economic opportunities for Aboriginal communities".9

In attempting to achieve certainty through the negotiation process, federal and provincial governments are mandated to balance the rights of Aboriginal beneficiaries

\footnotetext{
$7 \quad$ Union of British Columbia Indian Chiefs, "Certainty: Canada's Struggle to Extinguish Aboriginal Title", (1998) UBCIC < http://www.ubcic.bc.ca/certainty.htm> (last modified: 23 February 2005) at 3. [hereinafter UBCIC] accessed: 03

Answers.com Dictionary, online: GuruNet $<$ http://www.answers.com/topic/relinguish $>$ (date March 2005) s.v. relinquish

9 Indian and Northern Affairs Canada, "Claims and Indian Government Sector" (2004), online: INAC < http://www.ainc-inac.gc.ca/ps/clm/index_e.html> (last modified: 01 August 2004).
} 
against the interests of the general public and the Crown. This includes providing economic opportunities for Aboriginal groups and third parties, ensuring public access to lands and resources, and the ability of the government to issue permits to ensure that they are promoting partnerships. ${ }^{10}$

Prima facie, certainty appears to be advantageous to all sides. The 1995 Hamilton Report asserts that certainty is achieved by "assuring that issues [affecting everyone involved] have been dealt with to everyone's satisfaction, and their rights are protected in the treaty."11

However, as the models for certainty currently stand, Hamilton's definition is not being achieved. For example, the only party to have rights extinguished, surrendered or modified happens to be Aboriginal groups. Aboriginal organizations, such as the Assembly of First Nations (AFN), have long argued that "First Nations [sic] have sought to have their rights recognized and implemented; the Federal government's primary goal has always been to extinguish the 'burden' of Aboriginal rights and minimize its legal obligation". ${ }^{12}$

The model of certainty that Aboriginal groups aim to achieve in their communities is a holistic approach. It is a model fashioned through the development of: "healthy communities, sustainable development, equal employment opportunities, strengthening cultural and linguistic identity and having objective standards to measure the success of the treaty". ${ }^{3}$ Therefore, "satisfaction" (i.e., certainty), as described by Hamilton, does not include the cancellation of rights for Aboriginal groups, yet this still takes place.

$10 \quad$ United Nations, Commission on Human Rights, Human Rights and Indigenous Issues: Report of the Special Rapporteur on the situation of human rights and fundamental freedoms of Indigenous people, by Mr. Rodolfo Stavenhagen, 2 December 2004. However, according to the 2004 Report of the Special Rapporteur on the situation of human rights, "Aboriginal people claim their rights to the land and its natural resources, as well as respect for their distinct cultural identities, lifestyles and social organizations".

11 Hamilton Report, supra note 5 at 38.

12 Assembly of First Nations, "Assembly of First Nations' Critique of Federal Land Claims Policies"

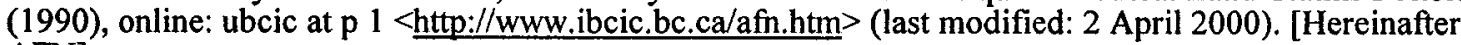
AFN].

13 Canada, Visions of Certainty: Challenging Assumptions, Law Commission of Canada, Speaking Truth to Power: A Treaty Forum by M. Stevenson (Ottawa: Minister of Public Works Canada, 2001) at 113-134. [hereinafter Stevenson]. 
The Crown, however, seeks a model of certainty that is meant to bring about finality to Aboriginal rights and title not defined in a treaty. Traditionally, this finality has come in the form of cede, release and surrender. In 2004, the Government of Canada accepted an alternative model of certainty that did not include the yielding of rights that may exist outside the treaty, known as a non-assertion model. However, the model is limited as a caveat/clause contained within the agreement that if the rights are exercised, without first being agreed upon, then the federal government can extinguish them. Satisfaction for the Government of Canada includes well defined rights and obligations, and finality of rights and obligations not detailed in legally binding agreements.

Based on the conflicting positions of the parties, problems continue to arise with the methods used to define and achieve certainty in relation to the ownership and use of lands and resources. These anomalies, such as the diverging concepts of certainty within the realm of law and politics, the differing interpretations ${ }^{14}$ and the conflicting ideologies ${ }^{15}$ on the best way to achieve certainty formed the basis for my inquiry. As such, the following research question will be explored: In settling land or treaty claims, could an alternative method be developed to achieve certainty that recognizes the interests of all parties, without Aboriginal groups having to cede, release, surrender, extinguish, or modify any rights that exist outside the treaty?

It is suggested that an alternative method to achieve certainty could be developed that recognizes the interest of all parties, without Aboriginal groups having to cede, release, surrender, extinguish, or modify any rights that exist outside the treaty. In order for this model to work, it is recognized that a definition of all parties and their interests is required.

In addition, there also needs to be a clearer understanding as to what certainty is meant to achieve and what the best method to achieve it is. Certainty, currently defined in

$14 \quad$ By governments, Aboriginal groups, third parties and the Canadian legal system.

15 Aboriginal groups and the Government of Canada enter into discussions with a structured set of ideas designed to reflect and protect a set of political, cultural and social beliefs. It is these beliefs that form the basis of the negotiation process and cause conflict as neither party wants to relinquish their position. 
a stringent legalistic mode that requires the relinquishing of rights and title, needs to be modified to reflect a model that allows for evolution of rights, relationship building and that accommodates the uniqueness of the current social situations within Aboriginal communities.

\section{B. Conceptual Framework}

Despite certainty's complexity and the fact that certainty is a fundamental problem in settling land claims, little scholarly research has been done explicitly on this issue. However, much academic research has been done on Aboriginal cultures, traditions and values, as well as on the significance of land, resource and environment as it pertains to their traditional way of life. ${ }^{16}$ Moreover, this research has highlighted the devastating effects that governmental policies and structures have had on Aboriginal people, their cultures, traditions and land base throughout Canadian history.

Authors such as J. Bodley, C. Tennant, and M.E. Turpel, note that the loss of culture and the surrendering of land to which Aboriginal people have been subjected is a form of ethnocide. ${ }^{17}$ R. Stavenhagen notes:

Ethnocide may be defined, briefly, as the process whereby a culturally distinct people... loses identity due to policies designed to erode its land and resource base, the use of its language, its own social and political institutions, as well as its traditions, art forms, religious practices, and cultural values... whatever the pretext: social progress, national unity, economic development, military security... ${ }^{18}$

Furthermore, J. Frideres notes:

...there are processes that have affected Aboriginal peoples in historical times as well as in the present. These structural impacts began to affect Aboriginal people at the time of contact

\footnotetext{
${ }_{16} \quad$ For examples see: M. Boldt and J.A. Long, eds., "Tribal Philosophies and the Canadian Charter of Rights and Freedoms", The Quest for Justice: Aboriginal People and Aboriginal Rights, (Toronto: University of Toronto Press, 1985). at 165-182. M. Thornton, Aspects of the History of Aboriginal People in their Relationships with Colonial, National and Provincial Governments in M. Thornton and R. Todd, Aboriginal People and Other Canadian: Shaping New Relationships (Ottawa: University of Ottawa Press, 2001) 7-27.

${ }_{17}$ For examples see: C. Tennant and M.E. Turpel, A Case Study of Indigenous Peoples: Genocide, Ethnocide and Self-determination, [1991] Nordic Journal International Law 287. J. Bodley, Victims of Progress, $3^{\text {rd }}$ ed. (California: Mayfield Publishing, 1990).

18 R. Stavenhagen, The Ethnic Question; Conflicts, Development and Human Rights, (New York: United Nations University Press, 1990) at 87.
} 
with Europeans and became increasingly influential as the immigrant population grew. ${ }^{19}$

As such, the erosion of Aboriginal traditions, values and cultures and the imposition of colonial structures, policies and legislation have greatly impacted on many Aboriginal communities' ability to move forward and build the necessary capacity to negotiate treaties as equals with the federal government. Thus, any proposed model of certainty cannot be solely linked to the process of negotiating a modern-day treaty. In order to be successful it must take into consideration the substantive issues facing a community as a result of European impositions and legislation, and establish a framework as to how these issues can be addressed.

The conceptual model presented in this paper will draw on academic research that demonstrates the impacts of various governmental policies on the socio-economic conditions in Aboriginal communities. Furthermore, it will argue that these conditions have resulted in a lack of capacity on the part of Aboriginal groups to negotiate and participate in the economy, and ultimately have resulted in the ceding, releasing and surrendering of rights and title.

This thesis is undertaken with the objective of establishing an alternative method of achieving certainty in relation to settling land claims..$^{20}$ By addressing the negative social and structural impacts of the past, I hope to fashion a model that is based on a reconciliation of rights as opposed to a surrender or modification of rights.

Moreover, this thesis will loosely adopt Hamilton's assertion that certainty is achieved by "assuring that issues [affecting everyone involved] have been dealt with to everyone's satisfaction, and their rights are protected in the treaty."21 Where Hamilton maintained that "everyone" should be so all encompassing as to include governments and

\footnotetext{
19 J. Frideres, Native Peoples in Canada: Contemporary Conflict, $4^{\text {th }}$ ed. (Scarborough: PrenticeHall, 1993) at 2.

${ }_{20}$ In order to assess the validity of this task a series of subsidiary questions were developed. Please see Appendix 3: Research Questions and Methodology.

$21 \quad$ Hamilton, supra note 5 at 38 .
} 
third party's rights spelled out in the treaty, I will assert that "everyone" should be restricted to Aboriginal beneficiaries, federal, provincial and territorial governments, with consideration and accommodation to third party rights when and where it is absolutely necessary to have them laid out in the treaty. This restriction avoids further complicating an already complex process.

The transfer of ownership and rights to large areas of land, resources and cash payments to Aboriginal communities are usually the major features of these claim settlements. Economic and social benefits can include participation in resource management, including water, wildlife, subsurface and offshore assets, as well as resource and revenue sharing. For the business community of an area under claim (i.e., unsettled), the uncertainty associated with an unsettled land claim can be far more damaging than that of the settled claim. The Hamilton Report concluded that certainty for all groups focussed around their desire to conduct business practices in a stable and predictable environment. Concerns for certainty in relation to a settled agreement or disputed land base also involved access to current and future resources.

From 1975 to present day, twenty-one land claim agreements have been signed between Canada and Aboriginal groups using various methods of certainty. (See Appendix 2: Certainty and Extinguishment Provisions in Comprehensive Land Claim Agreements). The evolutionary process of achieving certainty has been modelled under the premise that title to land is surrendered, and rights are extinguished and subsequently replaced by a treaty that includes a sum of money as well as defined rights, obligations and land base.

In analysing the ideal framework to achieve certainty, it will be argued that the fundamental principles articulated in the Hamilton Report should be adopted in a modified form (i.e., restrictions as to which groups' rights should be protected in the treaty), as the 
appropriate model. ${ }^{22}$ However, in order for a new model to work, Canada must recognize Aboriginal rights and title to lands and resources. While Canada currently accepts the notion that Aboriginal rights have been recognized by the courts and affirmed by the Constitution Act, 1982, it also argues that "given that rights are common law and not written down, their extent and nature have been subject to considerable debate". ${ }^{23}$

In addition, this thesis will argue that a new model must be flexible enough to accommodate diversity amongst the communities and grounded in the notion that certain structures must first be in place. As such, certainty is viewed as a form of reconciliation which aims to restore the relationship between the Crown and Aboriginal people through the settlement of differences as opposed to a client based relationship which resigns Aboriginal people to sever their connection to land and rights.

\section{Methodology}

This thesis used multiple lines of evidence such as interviews, questionnaires, case review, etc., to collect the information required to address the research and subsidiary questions. The intent of sending out questionnaires and interviews was to ensure that differing views were captured and to avoid a simple regurgitation of written material produced to date. (See Appendix 3: Research Questions and Methodology).

\section{Agreements, Case and Legislative Review}

A review of Canadian legislation was conducted to assist in outlining the methods used to achieve certainty. Particular attention was paid to the wording used in the certainty provisions. This was done in conjunction with an examination of court decisions, as they

\footnotetext{
22 These principles encompass the interests of all parties that are to be represented in throughout the negotiated process and well into the settlement. Hamilton suggests that in order to achieve certainty when settling land claims, six (6) factors are of particular relevance: 1) the preamble clause: which recognizes rights and the desire to achieve certainty; 2) mutual assurances: as a means of fostering equality and cooperation; 3) the rights and interests of parties in relation to lands; 4) dispute resolution; 5) judicial review; and 6) amendment process, which will be expanded upon in Chapters 4 and 6. 23 Assembly of First Nations, Material on Canada's Comprehensive Claims Policy, [unpublished, archived at the Library of Indian and Northern Affairs].
} 
relate to Aboriginal rights and title, to assess if the courts directly, or indirectly, dealt with the issue of certainty in rendering their decisions. (See Appendix 4 for a detailed chronological list of agreements, cases and legislation that were examined).

\section{Document Review}

The document review was conducted and included: governmental policies, Royal Commissions' findings and recommendations, task force findings, and position papers produced by various Aboriginal organizations and governmental departments. It was used to establish what, if any, the conflicting ideologies of the parties are, and how, if at all, these have changed. It was also used to examine the models of certainty deployed and proposed to date, and explore the differences and/or commonalities between the parties when achieving certainty. (See references).

\section{Literature Review}

The literature review was helpful in providing not only a historical context to the issue of certainty, but in extracting various theories or perspectives. Since my research question made the assumption that there are conflicting ideologies between Aboriginal organizations and governments, I had to draw on material that supported my assumption, while also addressing the data/research that contradicted it. (See references).

\section{Interviews}

Seven interviews were conducted with various representatives from Indian and Northern Affairs Canada and the Indian Claims Commission, to ascertain their views regarding the conflicting ideologies and the development of alternative models of certainty that would recognize the interests of all parties. Please see Annex A (Introduction Letter) and Annex B (Interview Guidelines) for more details. The interview guidelines were sent to the proposed interviewees along with an introductory letter to allow individuals time to review the questions and assess if they would like to partake in the interview. 


\section{Questionnaires}

A small questionnaire was sent to 16 of the 19 Aboriginal communities that already settled land claim agreements; at the time I began my research, some of the agreements were only initiated and had not received royal assent. My rationale for sending it to the signatories of settled claims and not to those groups currently in negotiations, was two-fold:

a) these groups used the models that have been deemed by many, such as the AFN, Hamilton, and RCAP, to be problematic. I was interested in how they felt about the certainty clauses contained within their respective agreements and wanted to ascertain their opinions on the creation of an alternative model (see Annex C).

b) given the sensitive nature of land claims negotiations, seeking input from ongoing negotiation tables could impact the process. As my goal was to obtain feedback and not to unintentionally or negatively impact ongoing negotiating tables, this risk was mitigated by sending the questionnaire only to the 16 signatory/beneficiary groups.

By sending out questionnaires and interviewing people with differing epistemologies, it was hoped that the answers to the following questions would be obtained:

a) why would Aboriginal groups sign a modern-day treaty that calls for the extinguishment/cede/release/surrender of rights;

b) why the government does not accept a model of certainty based on mutual assurance;

c) what alternative models the parties being sent the questionnaires and those being interviewed would suggested; and

d) are there any commonalities in the models.

The questionnaire forms were sent via regular post mail, in both a paper and diskette form and included a pre-posted return envelope in order that the respondents could reply without incurring costs. This method also allowed individuals the opportunity to respond in written or electronic format. However, in light of the fact that I work for the Government of Canada, which was disclosed (see Annex A), I was not sure how receptive the 
communities would be in partaking in a questionnaire. 


\section{CHAPTER 2}

\section{THE EARLY FOUNDATION OF CERTAINTY ${ }^{24}$}

In order to ascertain if an alternative method to achieve certainty could be developed that recognizes the interests of all parties, it is essential to trace the origin of certainty. This is done to avoid falling prey to any mistakes made in the past and to establish what, if any, elements should be adopted or included in a new model.

Certainty, according to the Government of Canada, is a legal process in which undefined rights are exchanged for a package of defined rights, and rights not set out in the legal binding agreement are ceded, released, surrendered and/or modified. However, many Aboriginal groups and organizations fundamentally disagree with this approach. Instead, they view the legal process of certainty as a tool that is meant to sever their connection to the land and assimilate them into mainstream society. From this perspective, certainty is a powerful tool, and therefore, achieving certainty carries with it profound implications for Aboriginal peoples.

This chapter will show that the legal notion of certainty is rooted in historical common law cases, the enactment of legislation and policies ${ }^{25}$, and in the securing of a land base in the newly established colonies. Intrinsically, certainty as a legal process fails to take into consideration Aboriginal groups' notions of certainty as an objective process because it focuses on satisfying the needs of the crown. Furthermore, the chapter ties the notion of certainty to the treaty-making process and fails to take into consideration the unique social and economic issues within the community.

The wording contained in the doctrine of discovery, the Royal Proclamation Act and

\footnotetext{
$24 \quad$ Given the unique history between Aboriginal people and Canada, the events discussed in this paper will be restricted to those that directly impact and influence the achievement of certainty as it pertains to settling historical and modern-day treaties. While it is not the intent of this thesis to provide a comprehensive review of Aboriginal history, it is important to note that the attitudes and beliefs held towards Aboriginal people greatly shaped policies, legal decisions, etc., and were influenced by these other events. When reading this thesis, it is important to note that many other issues, which will not be discussed, were also at work in society and impacted on Aboriginal people.

${ }_{25}$ As they relate to Aboriginal rights and title.
} 
the Indian Act, show how certainty relating to land ownership was thought to be the exclusive right of the sovereign. However, an Aboriginal right to occupy was acknowledged in a limited fashion and restricted to a specific geographical area and dependent upon the goodwill of the sovereign. This chapter will explore the various historical events that shaped and changed the relationship between Aboriginal people and the federal government. It will further examine how the legal concepts of cede, release, surrender, and extinguishment (i.e., certainty) developed. As well as certainty's relationship to the doctrine of discovery, the Royal Proclamation Act, the Indian Act, a notion of Aboriginal title (as determined by the common law system), Aboriginal primitivism and other various principles of European superiority will be discussed. This section will cover the Period of Contact to 1975, and will include a discussion of how the early dynamics of 'internal colonialism'26 and power structures that were produced as a result of the colonialization process, shaped and developed Aboriginal title and the early models of certainty. It will be noted how these historical processes subsequently became the mechanisms used to achieve certainty as it pertains to the resolution of modern-day land claim settlements. This includes how the government sought finality of Aboriginal rights and title through surrender and extinguishment provisions, while Aboriginal groups negotiated from a nation to nation perspective with the view of creating a viable economic relationship.

\footnotetext{
26 Internal colonialism is the colonialization of one group (in this case Aboriginal people) by the more dominant group (i.e., Government) within Canada. Frideres, supra note 19 at 3 . For other examples of internal colonialism see: O.P. Dickason, Canada's First Nations: A History of Founding Peoples from Earliest Times, (Toronto: The Canadian Publisher, 1992), B. Morse, "Aboriginal Peoples and the Law" in B. Morse, ed., Aboriginal Peoples and the Law: Indian, Métis and Inuit Rights In Canada (Ottawa: Carleton University Press, 1991).
} 


\section{A. Aboriginal Title and the Importance of the Land}

"Prejudice has prevented non-Aboriginal society from recognizing the depth, sophistication and beauty of our culture . . . But this must change, or there will be immense suffering in the future in this beautiful land which the Creator has bestowed upon us."27

Chief Eli Mandamin

Kenora, Ontario, 28 October 1992

In order to understand the impact that achieving certainty has had on Aboriginal groups, it is necessary to understand the value Aboriginal culture has placed on the land since time immemorial. Aboriginal communities built their societies around a cosmoscentric ideology, in which an individual's self-interest was viewed as 'inextricably' intertwined with tribal survival. ${ }^{28}$ It was (and still is), according to Aboriginal metaphysical beliefs, the Creator who gives each person their distinct place and role to perform in the harmonious operation of nature, in a manner and under circumstances deemed appropriate to each person. ${ }^{29}$ Through the research of customs and 'oral traditions' ${ }^{30}$, passed down from generation to generation, it has been clearly established that "land is absolutely fundamental to Aboriginal identity..., [and] is reflected in the language, culture, and spiritual values of all Aboriginal peoples". ${ }^{31}$ Defined as hunting and gathering societies, Aboriginal groups developed survival techniques, hunting strategies, as well as agricultural technologies largely based on the traditional knowledge they gained of their ecosystems. The number of tribes across what is now called Canada was vast, with diverse methods of hunting, fishing, and farming being

\footnotetext{
$27 \quad R C A P$, supra note 1 at vol. 2 c. 2 p.5.

28 M. Boldt and J.A. Long "Tribal Philosophies and the Canadian Charter of Rights and Freedoms", in M.J. Mac Neil, N. Sargent, and T.A. Dawson, Introduction To Private Law Relationships, $2^{\text {nd }}$ Ed., (North York: Captus Press Inc., 1995) 149 at 149.

29 RCAP, supra note 1 at vol. 1 at 37.

30 Oral traditions, include the use of story telling, song, dance art, craft making, giving instructions and directions, were used to pass on specific cultural practises and values, language and laws, histories and family relationships. Oral traditions told of how the land was to be used for purposes that would please the Great Spirit and were considered by Aboriginal people to be equivalent to western codified laws. Aboriginal Oral Traditions, (2003) online: Frog and Toad $<$ http://www. frogandtoad.com.au/aboriginies/language4.html $>$, (last modified: 2 December 2003).

RCAP, supra note 1 at vol. 1 at 99.
} 
practised. As such, the value placed on the land was measured in tribal survival and not in monetary sums.

Prior to European contact, Aboriginal people used the land "to the extent that neighbouring tribes would not encroach upon the land and game without specific permission." 32 Furthermore, it was held as a fundamental belief that the 'Great Spirit' gave the land to Aboriginal peoples; as long as they occupied and cultivated the land, they had a right to it. Therefore, no exclusive rights or territorial ownership existed within the Aboriginal culture. ${ }^{33}$

For centuries after 'initial contact' ${ }^{34}$, Aboriginal peoples, for the most part, maintained distinct social and cultural domains from those of their European counterparts, despite the English Crown's assertion of rights "to the 'savage' held lands" in the new colonies. ${ }^{35}$ Throughout this period, colonial management measures were constructed by the English in relation to Aboriginal affairs in an attempt to ward off intercolonial rivalry and to prevent the French from carrying out trading practices with Aboriginal groups. ${ }^{36}$ As the territorial wars escalated between the French and the English, the desire to secure Aboriginal loyalties, for both the French and the English,

\footnotetext{
32 W. Badcock, Who Owns Canada?: Aboriginal Title and Canadian Courts, (Ottawa: Canadian Association in Support of Native Peoples, 1976) at 2.

${ }^{33} \quad$ Ibid at 3 . Slowely furthers this argument quoting Orlen Lyons, a traditional Mohawk elder who stated: "We native people did not have the concept of private property in our lexicon, and the principle of private property was pretty much in conflict with our value system. For example, you wouldn't see 'No Hunting', 'No Fishing' or 'No Trespassing' signs in our territories. To a native person such signs would have been the equivalent to saying 'No Breathing' because the air is somebody's private property. If you said to the people, 'The Ontario government owns all the air in Ontario, and if you want some you are going to have to go and see the Bureau of Air', we would all laugh. Well, it made the Indians laugh too when the Europeans said, 'We are going to own the land'. How could anyone own the land?" G. Slowely, "Aboriginal Self-Government, Extinguishment of Title and the Canadian State: Effectively Removing the "Other'?" (2000) 1 Native Studies Review 1 at 12.

${ }_{34}$ Initial contact was made in Canada in approximately 1497 by John Cabot. Cabot's expeditions were the first of Britain's claims to Canada. Another attempt was made in 1583 by Sir Humphrey Gilbert in what is now known as St. John's, Newfoundland. Gilbert's attempts to establish a new colony did not last long as he died on a return trip to England.

Badcock argues that this phenomenon subsisted largely due to the fact that the English had no desire to settle on Aboriginals' land at that particular time, as they were more interested in trading with their new neighbours. See W. Badcock, supra note 32 at 4 and R. Williams, The American Indian in Western Legal Thought, (New York: Oxford University Press Inc., 1990) at 215. Department of Indian Affairs and Northern Development (1999) Individuals Responsible for Aboriginal and Northern Affairs in Canada 1755 to 1999, online: Indian and Northern Affairs Canada <http://www.inac.gc.ca/pr/info/info38 e.html $>$ (last modified: 29 May 2000).
} 
became more pronounced. In approximately 1755 , the British Crown, in an effort to develop relations and cultivate military alliances with Aboriginal groups, constructed a unified Indian Department as a branch of the military. ${ }^{37}$ Military superintendents were charged with the responsibility of managing admirable relations with Aboriginal people and securing their allegiance to the British sovereign, which was needed during times of war to ensure victory. This coexistence was viewed as a period of mutual respect in which the negotiation of 'Peace and Friendship' treaties and trading practices became a fundamental component in assuring security of interests for both parties. ${ }^{38}$ For the most part, 'Peace and Friendship' treaties dealt with military and political relations (i.e., hunting, fishing, and trading practices) between Aboriginal nations and governmental representatives, with little or no focus on land claim issues. ${ }^{39}$ Both R. Williams and B. Morse have argued that the omission of land in early treaties was premised on the fact that individual land ownership was not as great a concern as it later came to be.

In 1760, French rule was extinguished with the fall of Montréal to British forces, ending the tumultuous war between the English and the French. While initially the Aboriginal population was roughly equivalent, in numbers to that of the European settlers, the dynamics quickly changed. ${ }^{40}$ As the war ended, and the number of European settlers increased, the Aboriginal population began to be decimated largely due to disease and war. The increased European immigration marked a pivotal shift in the relationship between Europeans and Aboriginal people. With their numbers dwindling, Aboriginal people were left in a vulnerable position, as many nations simply became too weak to protect their lands and resources. ${ }^{41}$ Encroachment on Aboriginal territories increased, as 
did the sovereign's assertion over Aboriginal people. ${ }^{42}$ The limitation of Aboriginal land rights, set within a colonial framework, commenced with the assertion of the 'doctrine of discovery', in which the sovereign claimed to own the legal title to the lands within the North American borders by virtue of 'terra nullius ${ }^{43}$, discovery ${ }^{44}$ or conquest ${ }^{45}$.

According to B. Morse, concepts such as the doctrine of discovery were constructed as a means in which European nations articulated claims against each other to spheres of control within the western hemisphere, and were never intended to be applied towards Aboriginal people. ${ }^{46}$ While Aboriginal people did not necessarily lose their interest or right to use the land, the exact nature of this 'Aboriginal title' was not clearly defined, although it initially included the right to occupy, fish and hunt and was known to be communal in nature. ${ }^{47}$ According to W. Badcock, Aboriginal people, "with no legal system of holding land at the time the British sovereignty was imposing their common law system, could not bring up an equivalent basis for a claim." ${ }^{\text {48 }}$ This is further supported by B. Slattery, who notes that "Aboriginal nations did not qualify as international entities because of such factors as their modest size, mobile lifestyle, diffuse political structures and differing religious beliefs". ${ }^{49}$ As the colonies continued to expand, the state asserted more forcefully its political power over Aboriginal people, thus intensifying the internal colonialization process of Aboriginal people. The state created policies that ignored, or attempted to curtail, Aboriginal peoples' values, norms and

\footnotetext{
$42 \quad$ W. Badcock, supra note 32 at 5 .

43 RCAP, supra note 1 at vol.1 at 44. Terra Nullius is Latin for empty, uninhabited land

44 Under the principle of 'discovery', the British domain would have an exclusionary right to acquire the land from any Aboriginal group occupying land in the new world. B. Morse, "Aboriginal Peoples and the Law" in B. Morse, ed., Aboriginal Peoples and the Law: Indian, Métis and Inuit Rights In Canada (Ottawa: Carleton University Press, 1991) 1 at 37.

G. Barrell, R. Young and R. Price, Indian Treaties and the Law: An Interpretation for Laymen, (Alberta: Indian Association of Alberta, 1975).

$46 \quad$ B. Morse, supra note 44 at 37.

$47 \quad$ G. Barrell, R. Young and R. Price, supra note 45 at 1.

48 W. Badcock, supra note 32 at 35.

49 B. Slattery, "The Organic Constitution", (1995) 39 Osgoode Hall L. J. 103.
} 
cultural practises, systematically creating Aboriginal underdevelopment. ${ }^{50}$ This was all done despite the fact that Aboriginal people argued that the European legal system was a foreign and unrecognizable system to them.

\section{B. The Conception of Certainty}

"Our Sacred connection to the Land is certain.

Our relationship with the Land, our Title, rests over every square inch Of our traditional territories:

Every rock, mountain top, stream, valley and tidal swell. This is certain.

Indigenous Peoples have the jurisdiction and responsibility to protect, access and use the Land and resources upon the Land for the benefit of our Peoples. This is certain.

Our own traditional laws and teachings grant us this certainty: As long as we maintain our Sacred connection to the Land we continue to exist as Peoples."

Before exploring the legislation that shaped the current concept of certainty, it is important to define four additional concepts that are synonymous with a legal articulation of the term certainty. These are cede, release, surrender and extinguish, and have been used throughout historical and modern-day treaties and early legislation. The MerriamWebster's Dictionary defines the terms as follows: cede: "yield or give up to another, esp by treaty; to assign or transfer title" and surrender: "to deliver over, yield (to another); to give up, relinquish (eg. a right to a claim)"s4. In 1996, RCAP noted that extinguishment, as defined by Black's Law Dictionary, was "the destruction or cancellation of a right". 55

The significance of these terms focuses on the taking away, giving up, or cancellation of rights. They were further incorporated into treaties to ensure that lands

\footnotetext{
so Frideres argues that the Canadian government (and society) created a "culture of poverty" by replacing Aboriginal peoples' traditional mode of production with one that required specific skills and knowledge in which Aboriginal peoples were denied training, education and entry in the labour market. See J. Frideres, supra, note 19 at 8 and 66.

Si UBCIC, supra note 7 at 1 . [Emphasis Added].

Merriam-Webster's Dictionary, online: Merriam-Webster <http://www.m-w.com/ $>$ (date accessed: 25 April 2005) s.v. cede.

$53 \quad$ Ibid. s.v. release

$54 \quad$ Ibid. s.v. surrender

5s Canada, Royal Commission on Aboriginal Peoples, Treaty Making in the Spirit of Co-existence: An Alternative to Extinguishment (Ottawa: Supply and Services, 1995) at 8.
} 
and resources were acquired by the Crown to secure sovereignty; thus also making existing models of certainty an objective-based process as some gains could be measured. However, certainty, even as an objective-based process, still falls short of achieving a certainty fashioned after healthy and sustainable communities as sought by Aboriginal people. This section will explore how these concepts developed from the enactment of early legislation and lead to the dispossession of large areas of Aboriginal title and resources.

In 1763, the Dominion passed the Royal Proclamation Act of 1763 (RPA), also known as the "Magna Carta of Indian Rights" measure to recognize the loyalty of Aboriginal groups who had fought for England, the $R P A$ became one of the most important documents pertaining to Aboriginal people. ${ }^{57}$ First, the process for achieving certainty over lands and resources was developed through the ceding of Aboriginal title to land to the Crown and subsequently replacing it with a form of compensation, treaty or trust. It is this notion of certainty (e.g. ceding of rights and title) that would influence and shape the models used in the settlement of modern-day treaties.

Furthermore, the $R P A$ established ongoing governmental fiduciary obligations towards Aboriginal people. Both the Assembly of First Nations (AFN) and the Indian Claims Commission (ICC) argue that the ceding or purchasing provisions ${ }^{58}$ contained in

\footnotetext{
56 B. Henderson, "A brief Introduction to Aboriginal Law in Canada", online, $<$ http://www.bloorstreet.com/200block/brintro.html $>$ (last modified: 15 January 1996).

Komar argues throughout his paper that the wording in the Royal Proclamation Act suggests that the Act was designed to be a temporary measure in order to secure lands and allow Canada to grow as a Nation. See R. Komar, supra note 38. Dickason also touches on this point in her summary of the $S t$. Catherines Milling and Lumber case in which Oliver Mowat, the Premier of Ontario at the time of the case, argues that it was "a provisional arrangement...expressly repealed by the Quebec Act of 1774". See, O.P. Dickason, supra note 40 at 341.

58 The ceding and purchasing provisions in the $R P A$ read as follows: "upon any Lands whatever, which, not having been ceded to or purchased by Us as aforesaid, are reserved to the said Indians, or any of them. And We do hereby strictly forbid, on Pain of our Displeasure, all our loving Subjects from making any Purchases or Settlements whatever, or taking Possession of any of the Lands above reserved, without our especial leave and Licence for that Purpose first obtained.

And We do further strictly enjoin and require all Persons whatever who have either willfully or inadvertently seated themselves upon any Lands within the Countries above described or upon any other
} 
the $R P A$ "created within government an ongoing fiduciary responsibility to protect Indians and Indian lands"

...Indians who We are connected, and live under our Protection, should not be molested or disturbed in the Possession of such Parts of our Dominions and Territories as, not having been ceded to or purchased by Us, are reserved to them, or any of them, as their Hunting Grounds. ${ }^{60}$

Since lands could only be surrendered to the Crown, the $R P A$ seems to imply that it was the Crown's duty to act in the 'best interest' of Aboriginal groups by setting aside reserve lands, providing protection and acting as guardians of both.

The $R P A$, among other things, was meant to recognize and confirm a limited notion of Aboriginal title to the land, which Aboriginal people traditionally occupied. The intentions of the $R P A$ were to organize the British government's new land acquisitions; cease the encroachment on Aboriginal lands by new colonial settlers, which were threatening to plague any future dealings and trade with Aboriginal people; and to assist in the westward expansion and development in the new world. ${ }^{61}$

To fulfill its objectives, the $R P A$ cited a number of protective measures pertaining to Aboriginal people. For example, the RPA prohibited settlement on traditional Aboriginal lands held prior to a surrender of Aboriginal title to the Crown, as well as setting aside geographical lands designated as 'Indian Territory'. ${ }^{62}$ "In other

Lands which, not having been ceded to or purchased by Us, are still reserved to the said Indians as aforesaid, forthwith to remove themselves from such Settlements". Royal Proclamation Act of 1763 , R.S.C., 1985, App. II, No.1 [hereinafter RPA].

.99 Indian Claims Commission, The Facts on Claims, online: Indian Claims Commission $<$ http://www.indianclaims.ca/download/surreng.pdf $>$ (date accessed: 6 September 2004) at 1. $R P A$, supra note 58 at $\mathbf{s}$. IX. [Emphasis added]. The Royal Proclamation does not explicitly mention surrender or extinguishment.

${ }_{61}$ D. Whiteside and S. Whiteside, "Indians in Upper Canada from 1846 through 1885, with special reference to half-breed Indians and the development of political associations. The Circle is Broken." (Ottawa: Aboriginal Title Research Group, 1979). [unpublished, archived at the Library of Indian and Northern Affairs].

62 Native Law Centre, Constitutional Entrenchment, Legal Information Service, Report No.5 (Saskatchewan: University of Saskatchewan, 1980) at 2. 
words, cessions or purchases were not intended to result in land dispossessions that undermined Aboriginal interests". ${ }^{63}$

However, certainty was created for the government through the ceding of Aboriginal title and rights to all, or portions of, Aboriginal traditional territory to the Crown in exchange for trust or treaty. Both section $\mathrm{IX}^{64}$ and $\mathrm{XIII}^{65}$ of the $R P A$ became fundamental sections for influencing modern-day treaties for two reasons. First, these sections influenced the wording contained in early treaties as well as that contained within the certainty and ratification ${ }^{66}$ provisions found in modern-day settlements. In comparing wording found in the $R P A$ to that of the pre-confederation treaties by the Chippewa/Ojibbewa Indians (1781), against the Mississagua Indians (1843), and subsequently the post-confederation modern day treaty of the Inuvialuit in the Western Arctic Claim: The Inuvialuit Final Agreement (1982), striking similarities in the wording appear. For example, the Chippewa/Ojibbewa surrender states:

...in behalf of ourselves and all others or our Nation the Chipwas, who have or can lay claim to the hereinmentioned Island, as being their Representatives and Chiefs, by and with mutual consent do surrender and yield up into the hands of the Lieutenant Governor Sinclair, for behalf His majesty George the Third...and we do hereby make for ourselves and posterity a renunciation of all claims in future to said Island... ${ }^{67}$

Mississagua surrender reads:

...the receipt whereof is hereby acknowledged, have surrendered, granted and yielded up, and by these presents do surrender, grant and yield up unto Her said Majesty

$63 \quad R C A P$, supra note 55 at 13.

64 Section IX states: "...Indians who We are connected, and live under our Protection, should not be molested or disturbed in the Possession of such Parts of our Dominions and Territories as, not having been ceded to or purchased by Us, are reserved to them, or any of them, as their Hunting Grounds".

${ }_{65}$ Section XIII states: "...if at any Time any of the said Indians should be inclined to dispose of the said Lands, the same shall be Purchased only for Us; in our Name, at some public Meeting or Assembly of the said Indians..." [Emphasis added].

66 Ratification provisions are set out in the final agreement. Ratification requires that a majority of the eligible voters enrolled on the claimants group's voter list vote in favour of approving the agreement. The agreement must be ratified by the community before being passed through federal and provincial legislation.

67 Canada, Indian Treaties and Surrenders From 1680 To 1890, vol.1 (Ottawa: Fifth House

Publishers, 1992) at 1. 
Queen Victoria, Her heirs and successors, all and singular those certain parcels or tracts of land... ${ }^{6}$

Two hundred years after the signing of pre-confederation Treaty 1 , similar wording with the same intent appears in section 3(11) of the Inuvialuit modern-day treaty, which reads:

The Settlement Legalisation shall provide that Canada recognizes and gives, grants and provides to the Inuvialuit the rights, privileges and benefits specified in this Agreement in consideration of the cession, release, surrender... ${ }^{69}$

Between the period of 1763 to approximately 1899, the British Crown initiated and signed twenty-four treaties with various Aboriginal groups, all containing surrender provisions. Initially, cash settlements were offered for lands surrendered, but later the Crown compensated Aboriginal groups by setting aside reserve lands and provided subsidies along with various other forms of benefits. ${ }^{70}$

By the mid 1800s, the inflow of European settlers seeking land intensified, especially in southern Ontario. ${ }^{71}$ This influx drove up the prices of lands in southern Ontario and resulted in ever increasing encroachment on Indian lands. ${ }^{72}$

Around 1840, the Indian Department - Indian Affairs, the federal department responsible for Aboriginal issues and relations, set forth the goal of assimilating Aboriginal people into mainstream society. In 1869, Canada enacted the Gradual Enfranchisement Act $^{73}$ (replacing the Gradual Civilization Act, 1857). Initially, it was created as a way for Aboriginal men (and later extended to unmarried women) to voluntarily enfranchise and assimilate into mainstream society. Enfranchisement thus and Government Services Canada, 1997).

D. Whiteside and S. Whiteside, "Indians in Upper Canada from 1846 through 1885, with special reference to half-breed Indians and the development of political associations. The Circle is Broken." (Ottawa: Aboriginal Title Research Group, 1979). [unpublished, archived at the Library of Indian and Northern Affairs]. 
became "the process by which an Indian was 'permitted' by the authorities of the Indian Department to withdraw from protection of the Indian Department and to hold land in fee simple" ${ }^{74}$ Without becoming enfranchised, attempts or petitions by Indian Bands to attain deeds/title to the land they occupied were always denied. ${ }^{75}$ This policy allowed the government to take advantage of Aboriginal people by expropriating lands and/or denying ownership, and in doing so, creating the legal certainty it desired, to further its own economic interests. ${ }^{76}$

In 1870, Canada's land base was expanded through an amendment of the British North America Act ${ }^{77}$ (now know as the Constitution Act, 1867), when it acquired Rupert's Land and the North-West territory (now known as the Northwest Territories) from the Hudson's Bay Company. Further expansion took place when Manitoba joined the Canadian federation in 1870, followed closely by British Columbia (1871) and Prince Edward Island in $1872 .{ }^{78}$

Upon the enactment of the Constitution Act, $1867^{79}$ [formerly known as the British North America Act], s.91(24) accorded the Federal government administrative

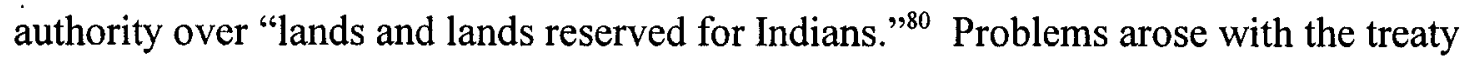
policy when the provinces that entered into Confederation had already allowed colonial settlers to encroach upon 'Indian' lands without signing treaties or offering any compensation. ${ }^{81}$ In 1875 , the federal government attempted to cease land infringement

\footnotetext{
74 D. Whiteside and S. Whiteside, supra note 69 at 14. According to the Duhaime Law Dictionary the definition of fee simple is: "The most extensive tenure allowed under the feudal system allowing the tenant to sell or convey by will or be transferred to an heir if the owner dies intestate. In modern law, almost all land is held in fee simple and this is as close as one can get to absolute ownership in common law". Duhaime's Law Dictionary, online: Duhaime's Law Dictionary <http://www.duhaime.org/dictionary/dictgh.htm\#H> (date accessed: 03 September 2004) s.v. fee simple.

$76 \quad$ Ibid.

$76 \quad$ RCAP, supra note 58 at 9.

77 Constitution Act, 1867 (UK), 30 \& 31 Vict., c. 3, reprinted in R.S.C. 1985, App. II, No 5.

78 Alberta and Saskatchewan did not join the Confederation until 1905 followed by Newfoundland in

1949.

8o Constitution Act,

81 D. Whiteside and S. Whiteside, supra note 71 at 203.
} 
and secure provincial cooperation by legislating that any provincial land measure that did not take into account Aboriginal interests would not be legally binding.

In British Columbia (BC), where a great deal of encroachment continued to take place, the BC government stood steadfast in refusing to participate in the federal government's policy and firmly refused to recognize an underlying "Indian title" 82 BC's rationale was the principle of terra nullius in conjunction with the fact that the province was outside the geographical area noted in the $R P A$. It was the former principle that guided Aboriginal policy in BC until approximately 1995. This allowed the province to benefit socially and economically through the accumulation of Aboriginal lands, resulting in further alienation of Aboriginal groups.

As with the RPA, the $B N A$ Act maintained the notion of Aboriginal people as having special status since they were explicitly mentioned in both documents. However, this special status did not produce favourable outcomes, and instead resulted in a series of legislative initiatives aimed at civilizing and enfranchising Aboriginal peoples. In 1876, nearly ten years after the BNA Act was enacted; Parliament passed the first Indian Act ${ }^{83}$, which was to be administered under the then Department of Indian Affairs [now INAC]. The Indian Act was comprised of various legislative acts and policies, such as The Gradual Enfranchisement Act, An Act to prevent trespasses to Public and Indian lands ${ }^{84}$, and An Act Respecting the Management of Indian Lands and Property (and so forth), that had been administered by the federal department. The legislation gave the federal government greater power and control over Aboriginal peoples living on reserves, as well as reinforcing with greater assertion, s. 91(24) of the Constitution Act and the underlying cession provision set out in the Royal Proclamation Act, while contradicting the notion of

$82 \quad$ O.P. Dickason, supra note 40 at 262 . Fifteen treaties in total were signed in BC prior to it entering into confederation. Fourteen of these were signed between 1850-1854 and are commonly referred to as the "Douglas Treaties".

${ }_{84}^{83}$ An Act to amend and consolidate the laws respecting Indians, 1876, c.28 [hereinafter Indian Act] 84 An Act to prevent trespasses to Public and Indian Lands, C.S.U.C., 1859, c.81. 
protecting 'Indian' lands and rights. The Minister of Indian Affairs was granted sweeping powers over the "control and management of the reserve lands, money and property of Indians in Canada". ${ }^{85}$

D. Paul argues that the Indian Act supported the current practise of dispossessing of Indian land because of sections such as s. 43 that penalized any agent who did not exert an effort to sell off Indian lands. ${ }^{86}$

If any agent appointed or continued in office under the Act knowingly and falsely informs, or causes to be informed, any person applying to him to purchase any land within his division and agency, that the same has already been purchased, or refuses to permit the person so applying to purchase the same according to existing regulations, such agent shall be liable therefor to the person so applying in the sum of five dollars for each acre of land which the person so applying offered to purchase, to be recovered by action of debt in any court, having jurisdiction in civil cases to the amount. ${ }^{87}$

This section seemed to put the government in a moral, if not ethical, dilemma, since it was entrusted to the position of being responsible for Aboriginal people and their lands. ${ }^{88}$ Despite the dilemma, the government, in an effort to ensure compliance and secure control over 'Indian' lands, amended the Indian Act in 1889, which gave the federal government an override provision if an Aboriginal group was unwilling to lease a portion of its land to the Crown. ${ }^{89}$

Between 1870 - 1930, Canada presented an ever more coherent and comparatively successful treaty negotiation policy to resolve unsettled land claims, one that was beneficial to Canada. ${ }^{90}$ Eleven treaties were signed during 1871 to 1921 throughout western and northern Canada in order for construction to begin on a transcontinental

\footnotetext{
85 An Act Respecting the Management of the Indian Lands and Property, S.C. 1860. C.151.

86 D. Paul, Indian Act, 1867.online: danielnpaul <http://www.danielnpaul.com/ia1876.html $>$ (last modified: unknown) at 1 . Indian $A c t$, supra note 83 at $\mathrm{s} .43$

${ }_{88} \quad$ Ibid. [Emphasis Added].

${ }_{88}$ As previously noted, the RPA and s.91(24) of the Constitution Act created a duty on the part of Canada with respect to Aboriginal peoples. S. Harring, White Man's Law: Native People in Nineteenth Century Canada Jurisprudence, (Toronto: University of Toronto Press, 1988) at 127-128.

$89 \quad$ RCAP, supra note 1 at vol. 1 at ch. 9

90 R. Daniel, A History of Native Claims Processes in Canada, 1867-1979, (Ottawa: Minister of Indian Affairs and Northern Development, 1983).
} 
railroad which would run from the East coast to the West coast of Canada. The railroad was a national vision for Sir John A MacDonald, who felt that economic unification among the provinces would have been less likely in the absence of a unifying transportation and communication system. ${ }^{91}$ The building of the railroad had an enormous impact on Aboriginal groups, who either surrendered or had large tracts of lands expropriated in satisfying the national vision. ${ }^{92}$

It is clear that the main objective of the treaties was "to clear the land of the First Nation title acknowledged in the Royal Proclamation." 93 Duncan Campbell Scott, deputy superintendent of Indian Affairs reinforced the government's belief:

Our objective is to continue until there is not a single Indian in Canada that has not been absorbed into the body politic, and there is no Indian question. ${ }^{94}$

To this day, there is much debate over the extent to which First Nations truly understood the nature of the treaties they were signing. ${ }^{95}$ This debate stems from language barriers, differing culture, political and legal practices and the conditions under which the negotiation between Aboriginal communities and the Crown took place. J. Borrows argues that the treaty process was flawed, since there was no "consensus or 'meeting of the minds' on the question of the Crown receiving sovereignty or underlying Aboriginal title to the land from Aboriginal people".96

\footnotetext{
91 D. Whiteside and S. Whiteside, supra note 71 at

$92 \quad$ Ibid.

93 G. Prest, "Overview of the Aboriginal Land Question in BC" (1997) online: ubc $<$ http://www.library.ubc.ca/ereserve/frst 100/overview,htm> (date accessed: 14 April 2002) at para 8 . Ibid.

According to governmental practices, the scope or purpose of treaty making is to take undefined rights and exchange it for defined rights set out in the treaty. For examples that discuss the different ideologies of the treaty process, see Fred Plain "Aboriginal Rights: A Treatise on the Rights of the Aboriginal Peoples on the Continent of North America" in J.A. Long, M. Boldt, and L.L.Bear, Aboriginal Rights: Toward An Understanding (Alberta: University of Lethbridge, 1983).

96 Canada, Questioning Canada's Title to Land: The Rule of Law, Aboriginal Peoples and Colonialism, Law Commission of Canada, Speaking Truth to Power: A Treaty Forum by J. Borrows, (Ottawa: Minister of Public Works Canada) at 2.
} 


\section{The Legal Battles Surrounding Aboriginal Title and European Discovery}

"There is not one stick of timber, one acre of land, or one lump of lead, iron or gold that does not belong to the Dominion, or to the people who purchased from the Dominion Government. ${ }^{, 97}$ Sir John A Macdonald

In the 1800 s and $1900 \mathrm{~s}$, the question of Aboriginal title focussed on to what extent Aboriginal communities could retain Aboriginal title to lands that the Crown claimed sovereignty over, and how could this title be lawfully extinguished?

In 1823, the United State's Supreme Court addressed the notion of discovery and title in the case of Johnson and Graham's Lessee v. M'Intosh ${ }^{98}$, which was focussed on the sale of a parcel of land deemed to fall in 'Indian Territory' contained within the $R P A .^{99}$ In deciding the case, Chief Justice Marshall of the U.S. Supreme Court addressed the concept of 'discovery', stating "that discovery was a doctrine meant to apply to the European powers for their own orderly conduct in dealing with Aboriginal people of North America". ${ }^{100}$ Chief Justice Marshall also emphasized that the 'doctrine of discovery' meant that Aboriginal people should have occupancy rights and that only the government could gain ownership to their property. ${ }^{101}$ The Chief Justice further noted:

an absolute title to lands cannot exist, at the same time, in different persons, or in different governments...[and] all our institutions recognize the absolute title of the

\footnotetext{
$97 \quad$ Ibid. at 339

$98 \quad$ Johnson and Graham's Lessee v. William M'Intosh, 21 U.S. (8 Wheaton) 543 (1823). In this case, the Piankeshaw tribe sold a parcel of land to Thomas Johnson and his business partners, ignoring the surrender of lands to the Crown provision set out in the $R P A$. Around 1817, the Piankeshaw tribe surrendered their lands (including the previously sold parcel) to the United States Government, who subsequently sold the same parcel of land that Mr. Johnson had acquired in 1776, to Mr. M'Intosh. Johnson and his business partners made an application before the court to have M'Intosh removed from the land, but failed, due to the provisions set out in the RPA. The Johnson and Graham along with Cherokee Nations v. State of Georgia, 30 U.S. (5 Pet.) 1 (1831) and Worcester v. State of Georgia, 31 U.S. (6 (Pet.) 515 (1832) became known as the Marshall trilogy. These cases were born from a growing federal government that was finding itself in increasing conflict with state governments over the extent of its powers.

Crown.

Under the provisions of the Royal Proclamation, 'Indian Lands' can only be surrendered to the

${ }_{100}$ L. Little Bear, "A Concept of Native Title", in M.J. MacNeil, N. Sargent, and T.A. Dawson, Introduction To Private Law, 2nd Ed., (North York: Captus Press Inc., 1995) 316 at 316. I01 Ibid.
} 
crown, subject only to the Indian right of occupancy; and recognize the absolute title of the crown to extinguish that right. ${ }^{102}$

As such, the state was the legal possessor of the land, and in this capacity could extinguish title "... by treaty, by the sword, by the exercise of complete dominion adverse to the right of occupancy or other..."103 Despite its minimalization of Aboriginal title, it gave credence to the fact that Aboriginal people occupied the lands prior to contact, which later became a fundamental element in meeting the criteria to have a claim to enter into the negotiation process under the Government of Canada's 1973 Statement on Claims of Indians and Inuit Peoples: A Federal Native Claims Policy. ${ }^{104}$ Conversely, it gave the government the legal certainty it sought (e.g. finality) by being able to extinguish rights and title via legislation or treaty.

In 1888, the Judicial Committee of the Privy Council (JCPC) reinforced a limited Aboriginal right relating to land in the case of St. Catherine's Milling and Lumber Company v. The Queen" ${ }^{105}$, in which Aboriginal title was described as a "personal and usufructuary right." 106 While the case itself came before the courts not directly as a

\footnotetext{
102 B. Slattery, Ancestral Lands, Alien Laws, (Saskatchewan: Native Law Centre, 1983) at 28.

103 T. Flanagan, First Nations?:Second Thoughts, ( Montreal: McGill University Press, 2000).

104 Under the 1998 Comprehensive Land Claims Policy, the federal government will only accept the claim if: "The organized society has occupied the specific territory over which it asserts Aboriginal title since time immemorial. The traditional use and occupancy of the territory must have been sufficient to be an established fact at the time of assertion of sovereignty by European nations." Indian and Northern Affairs Canada, Comprehensive Claims (Modern Treaties) in Canada (March 1996) online INAC $<$ http://www.inac.gc.ca/pr/info/trty e.html > (last modified: 23 April 2004). D. Elliot, Law and Aboriginal Peoples In Canada, 3rd Ed. (North York: Captus Press, 1997) at 25.

St. Catherines Milling \& Lumber Co. v. The Queen (1888), 14 App. Cas. 46 (JCPC). Note

that the spelling of "St. Catherine's" changes throughout the citations in this paper and is in keeping with the original citations in the court decisions. The lower courts referenced the spelling as "St. Catharine's" while the JCPC referenced it as "St. Catherine's". According to the JCPC the latter is believed to be the correct spelling. The JCPC's spelling will be used throughout the paper except in the citation of the lower courts.

${ }_{106}$ M. MacNeil, "Aboriginal Property and Ideology" in M.J. MacNeil, N. Sargent, and T.A. Dawson, Introduction To Private Law, 2nd Ed., (North York: Captus Press Inc., 1995) 327 at 330 . At the core of the case was a parcel of land once claimed by the Salteaux of Ojibway as traditional territory, who subsequently surrendered the rights and title to the Dominion, extinguishing all future interests in the land. The dispute began when the federal government issued the St. Catherines Milling and Lumber Company a lumber permit within an area of surrendered land. While the federal government had authority over "Indians and lands reserved for Indians', the province had authority over resources within the province, by virtue of the Constitution Act, 1867. The terms personal and usufructuary refers to an Aboriginal group's right to use and occupy lands for activities such as hunting, fishing, etc without owning the land. B. Slattery, "The Nature of Aboriginal Title," in O. Lippert ed., Beyond the Nass Valley: National Implications of the Supreme Court's Delgamuukw Decision (Vancouver: Fraser Institute, 2000), pp. 11-33
} 
question of Aboriginal title to a piece of land, its decision had far reaching implications. ${ }^{107}$ While the question before the lower courts should have been framed "to whom do lands pass under the $B N A A c t$ in regard to which there was no treaty with Indians until after Confederation?", the three opposing views - federal, provincial and defendant- shifted the focus. ${ }^{108}$ Instead, the question became "whether or not the Indians had ever possessed any right in the land covered by the Treaty?"109 Ultimately, the JCPC agreed with the province. ${ }^{110}$

However, the JCPC articulated the sentiment of the federal government by stating that "...the Crown has all along had a present proprietary estate in the land, upon which Indian title was a mere burden"." As such, policies restricting Aboriginal rights and

\footnotetext{
107 During the period of 1867-1890 there were 22 Canadian court cases which dealt with Aboriginal rights and title. Eight of these were cited in the St. Catherine's Milling and Lumber case. Furthermore, during the first 50 years, post Confederation, it was not uncommon for a case which pertained to federal and provincial division of powers to appear before the courts this way. Since the enactment of the Charter and Rights and Freedoms, Constitution Act, 1982, division of powers has become less of an issue in the courts as opposed to individual rights and freedom cases. G. Stevenson, Unfulfilled Union: Canadian Federalism and National Unity, $3^{\text {rd }}$ ed., (Trenton: Gage Educational Publishing Company, 1986) at 6.

The province of Ontario argued that since the interest was ceded to the Crown, the federal government had no right to the property and it therefore belonged to Ontario. The defendants, the St. Catharine's Milling and Lumber Company, argued that the Dominion had not acted ultra vires since: "the Parliament of Canada alone has the power to deal with Indians, because they are wards of the Crown of England. The power to deal with Indians rests with the Dominion authorities and the Provincial. As such the Dominion has exclusive right to accept the surrender of Indian lands. The Dominion pays for it and why should it not have it?" Intertwined within the legal dispute was the federal government's position which contended that they had always recognized Aboriginal title: "From the earliest times the Indians had, and were always recognized as having a complete propriety interest, limited by an imperfect power of alienation." The defendants countered the federal government's argument by noting: "In Canada, from the earliest times it has been recognized that title to the soil was in the Indians, and the title from them has been acquired, not by conquest, but by purchase."

${ }_{109}$ lbid.

110 However, the decisions handed down in the lower courts provide a contextual framework in regard to Aboriginal title and rights within the time period. This also held true of the federal government's policy regarding the civilization of Aboriginal people and title of the land. The Ontario Chancery noted in several places throughout the written judgement the right and desire of the federal government to civilize Aboriginal people. For example Justice Boyd notes: "Though it hath been and still is the usual practice of all proprietors to give their Indians some recompense for their land, and so seem to purchase it of them. Yet that is not done for want of sufficient title from the King or Prince who halth the right of Discovery, not of prudence and Christian charity least otherwise the Indian might have destroyed the first planters (who are usually too few to defend themselves) or refuse all Commerce and conversation with the planters, and thereby all hopes of converting them to Christian faith would be lost. Ibid. at 207. The province of Ontario in the SCC decision noted: “....at the time of discovery of America, and long after, it was an acceptable rule that heathen and infidel nations were perpetual enemies, and that the Christian prince or people first discovery and taking possession of the country became its absolute proprietors, and could deal with the lands as such..." St. Catharine's Milling and Lumber, supra note 105 at 597. iii lbid.
} 
title, legislative extinguishment, along with enfranchisement, would have been a solution to the burden.

In the end, the JCPC reaffirmed a limited Aboriginal right with regards to lands. This personal and usufructuary right, as it was classified, granted Aboriginal people a right to occupy the lands and to enjoy the benefits of its ecosystems, subject to the will of the sovereign. ${ }^{112}$ In essence, the JCPC gave validity to the provisions of the $R P A$, which stated that lands were reserved "under [Parliamentary] Sovereignty, Protection and Dominion" 113 , by certifying any Aboriginal rights and title that were in existence in Canada were created by the Royal Proclamation Act. The court also adopted the theory that Aboriginal peoples' "personal right to occupy was based on tenancy at will and sufferance and dependent on the goodwill of the sovereign." 114 Since early success was measured in the accumulation of lands and resources and economic growth of a nation, certainty was defined to ensure that lands were recognized as belonging to the sovereign and/or provinces as well as reinforcing the Crown's assertion of sovereign ruler.

For Aboriginal groups, this notion of certainty, occupancy - dependent on the good will of sovereign - contradicted their fundamental ideologies in relation to how they organized their governments, administered justice and managed their lands and resources. The principles laid out in this decision remained unchanged until 1973 in the case of Calder v. Attorney General of British Columbia. ${ }^{115}$

In Calder, the question of whether or not Aboriginal title existed, or had been extinguished in relation to Aboriginal groups in areas not covered by treaties or the Royal Proclamation Act, was the issue put before the Supreme Court of Canada (SCC). recommended the Indian Act be revised prohibiting anyone from raising funds to pursue matters pertaining to land. From 1927 until 1951, the Indian Act thus prevented First Nations from raising funds for the purpose of hiring a lawyer to pursue and protect their rights. However, the great depression and the second world war also played a major factor in suppressing Aboriginal issues as matters of national interests took precedence.
} 
Members of the Nisga'a Tribe, located in Nass Valley of British Columbia, argued that their Aboriginal title to certain lands had never been lawfully extinguished. While the Nisga' a people lost their case, based on a 'technical element ${ }^{\prime 16}$, the majority of the SCC held that there was a common law Aboriginal title, but were split 3-3-1 on whether or not the title could be extinguished by legislation.

The SCC held that Aboriginal title recognized at common law was based on an original and continuous occupation use. It was the first time the courts had supported a "general occupancy based right but even here, only a minority accorded it full unequivocal common law status". ${ }^{117}$ The significance of this decision lay in the fact that "Aboriginal rights existed throughout what is now known as Canada, at the time of first European contact; thereby challenging the Canadian claim to title". ${ }^{118}$

The Calder judgment, support for occupancy as the basis of title, overruled the JCPC depiction of Aboriginal title as deriving from the RPA. That transformed Aboriginal title in Canada by holding that "Aboriginal title is not dependent on any treaty, executive order, or legislative enactment". 119 The SCC also ruled that, "being a legal right [Aboriginal title] could not thereafter be extinguished except by surrender to the Crown or by competent legislative authority and then only by specific legislation". ${ }^{20}$ Ultimately, this decision was held as a victory for Aboriginal groups, not only for its recognition of land claim rights, but also for pushing the Federal Government to create a policy aimed at addressing land claim issues. ${ }^{121}$

\footnotetext{
$116 \quad$ "At the time the Calder case was decided by the Supreme Court, the British Columbia legislation required a fiat for legal actions that affected the Crown's own title to land." See D. Elliot, supra note 104 at 32. A fiat is an authoritative order or decree.

117 Ibid.

$118 \quad$ G. Slowely, supra note 33 at 7.

119 L. Rotman, Parallel Paths: Fiduciary Doctrine and the Crown-Native Relationship in Canada (Toronto: University of Toronto Press Inc., 1996).

$120 \quad$ Calder, supra note 2 at 93.

121 See Section 2 A: Modern Day Treaties, which expands on the creation of the Comprehensive Land Claims Policy.
} 
The Supreme Court of the Northwest Territories gave further consideration to the idea of occupancy based rights under common law in the case of Re Paulette and the Registrar of Land Titles. ${ }^{122}$ In this case, an application was made to the courts to stop the Crown from developing the land, on the pretext that First Nation people "were asserting a claim to legal title in the land by virtue of their occupation prior to the entry of the colonial government in the area". ${ }^{123}$ After careful consideration and review of various decisions handed down in the United States and Great Britain, Justice Morrow decided that the Aboriginal group could be "prima facie owners of the land". ${ }^{24}$ In doing so, Justice Morrow also decided that four well-established criteria must be met in order for Aboriginal people to assert they were in occupation of the land before the Crown. First, the group must have a "possessory right [i.e.,] right to use and exploit the land", and secondly, the right would have to be communal in nature. ${ }^{125}$ Thirdly, "there is a Crown interest underlying this title...,[and fourthly] it is inalienable" and as such is incapable of being surrendered, transferred or alienated. ${ }^{126}$

While the Courts did sanction limited Aboriginal rights and title along with a limited relationship between Aboriginal groups and the Crown, it has been generally characterized as a relation between unequals. ${ }^{127}$ This unequal distribution of powers gave the government the upper hand when addressing Aboriginal issues, title to lands and treaties, as well as reinforcing a patronizing attitude, which prevented the Crown and the Court from considering the traditional knowledge, respect and attitude that Aboriginal people held towards the land.

122 Re Paulette et al. and the Registrar of Land Titles (1975), 63 D.L.R. (3d) 1 (also reported: [1976] 2 W.W.R. 193). Also see W. Badcock, supra note 32 at 27.

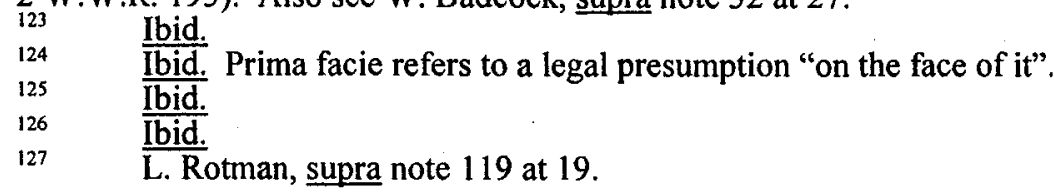




\section{Summary of the Early Frameworks for Claims and Certainty}

"The Treaties between the First Nations and the Crown are the connecting thread of the history of Canada." 128

Treaties, as well as claims for land and title, have always been a part of Canadian history, with nation to nation treaties among Aboriginal people dating further back than Canada's birth as a country. Oral history indicates that for Aboriginal groups, the process of treaty-making had always been conducted with other First Nations, "for purposes of trade, peace, neutrality, alliance, the use of territories and resources and protection". ${ }^{129}$ Therefore, it is argued, according to J. Youngblood Henderson, that the nature of these early treaties was conceived on the notion of creating "a permanent living relationship". 130 It could further be argued that early treaties served as the mechanism for the settlement of comprehensive claims in the years that were to follow by attempting to establish certainty by generating future dealings (on the part of First Nations) and provided a surrender and/or extinguishment model of certainty (on the part of the Crown). From an examination of early treaties and academic research, it is evident that Aboriginal groups sought political and economic certainty in the form of relationships and compensation for encroachment upon their land. For example, the First Nation community in the Lake of the Woods region were unwilling to grant colonial settlers safe passage through the proposed "Dawson Route" without first receiving compensation for their Aboriginal title. ${ }^{131}$ An Aboriginal understanding of treaties is highlighted by the principles set out by the Two Row Wampum belt, which characterizes Aboriginal and non-Aboriginal

\footnotetext{
128 Canada, Royal Commission of Aboriginal Peoples, Reclaiming Our Nationhood, Strengthening Our Heritage, (Ottawa: Supply and Services, 1993).

$129 \quad R C A P$, supra note 1 at 8.

130 J. Youngblood Henderson, "Empowering Treaty Federalism in Postcolonial Canada" (1994) [unpublished, archived at the Library of Indian and Northern Affairs] 36 at 139.

R. Daniel, supra note 90 at 3
} 
relationships as those of equals, with neither of the two parties trying "to steer the other's vessel". 132

Both the Royal Proclamation Act and the Indian Act were originally intended to provide a model of certainty for both the growing nation and Aboriginal peoples. According to Henderson, "the purpose of the Indian Act was to implement the obligations of treaties, royal instructions, and the Royal Proclamation Act into federal law in order to clarify national obligations". ${ }^{133}$ As Canada forged ahead as a nation, building railroads, cities and infrastructures, lands once held by Aboriginal peoples were required to ensure Canada's survival. Through treaties and surrender provisions in the Indian Act and the Royal Proclamation, the government sought the certainty they needed by assigning certain lands (i.e. reserves) to Aboriginal peoples as well as ensuring that lands designated as 'Indian territory' could only be surrendered to the government. For the most part, in early relations with Aboriginal groups, the government sought to secure certainty and minimize the perceived risk and threat associated with Aboriginal communities through two forms of extinguishment, "large-scale dispossessions of Aboriginal lands and resources [as well as] land cession provisions in numerous treaties". ${ }^{134}$ The early history of Canada reveals how the government justified this practice of surrender or extinguishment by virtue of terra nullius, conquest or discovery, and through the notion of parliamentary sovereignty. In this model, title to land is surrendered, and rights are extinguished and replaced by a treaty agreement that includes a sum of money as well as defined rights. The government believed that they had achieved certainty by signing treaties and ensuring that they contained surrender provisions, thus severing any Aboriginal connection to the land. ${ }^{135}$

\footnotetext{
132 Guswhenta (Kaswehntha) - Two Row Wampum Belt, online: hometown AOL <http://hometown.aol.com/miketben/miketben.htm> (date accessed: 17 February 2003) at 1. Henderson, supra note 130 at 168. 134 Canada, Royal Commission on Aboriginal Peoples, Extinguishment of Rights of Aboriginal Peoples: Problems and Alternatives, (Ottawa: Supply and Services, 1995).

135 J. Youndblood Henderson, supra note 130 at 155
} 
Through the legal decisions that arose during this time-frame, Aboriginal groups saw what they believed to be full title and rights shift from a 'personal and usufructuary' right to a limited recognition of title. The 1973 Calder case, which recognized a common law Aboriginal title based on original and continuous occupancy, marked a shift in the way that the federal government looked at settling unresolved land claim issues. The introduction of In All Fairness: A Native Claims Policy (now the Comprehensive Land Claim Policy) was designed to lay out the principles to negotiate treaties in a modern-day setting that were originally put forth in the 1973 INAC policy statement. ${ }^{136}$ From its inception, conflicting ideologies between Aboriginal organizations and groups, the federal government and provincial/territorial parties ensued. One of the major stumbling blocks was the use of blanket extinguishment to achieve certainty in the settlement of modern-day treaties. ${ }^{137}$ As D. Culhane notes, "at precisely the same moment the Crown recognizes title, Aboriginal people must surrender it". ${ }^{138}$

As previously discussed, Aboriginal communities, from early on, faced a great deal of instability in relation to loss of lands, displacement, economic restriction and infringement of rights. From an examination of early treaties and documentation, it is revealed how Aboriginal groups sought certainty for their future and compensation for encroachment upon their land. Unfortunately for both parties, but more so for Aboriginal groups, the treaty-process and notion of achieving certainty took on different meanings for each party. Therefore, the certainty that Aboriginal groups sought in signing treaties was meant to be viewed as a firm commitment to establish and maintain a mutual ongoing commitment to ensure treaty promises were fulfilled, that Aboriginal rights would be protected, and that the land would be mutually governed.

\footnotetext{
136 Department of Indian Affairs and Northern Development (1981) In All Fairness: A Native Claims Policy, Minister of Supply and Service Canada, Ottawa. [Hereinafter In All Fairness].

137 Under the 1981 Comprehensive Claims Policy, 'blanket extinguishment' refers to the extinguishment of all land claims based on Aboriginal title in exchange for conferral of specific rights and benefits. See Appendix 2: Certainty and Extinguishment Provisions.

${ }_{138}$ D. Culhane, The Pleasure of the Crown: Anthropology, Law and First Nations, (Burnday, Talonbooks, 1998) at 347.
} 
Other treaties reveal the interim measures taken by both the government and Aboriginal groups, such as permitting settlement on lands in exchange for a more encompassing treaty agreement. For example, the Nishnawbe Aski Nation, signatories to Treaty 9 noted that: the treaty was a "sharing treaty" in that the Indigenous nations agreed to share the use and occupation of the land with the non-Native governments in exchange for such things as: annuities; education, protection; the establishment of sufficient land bases (i.e. reservations); due compensation for public rights of way and appropriation of reserve lands; as well as the continued use of traditional lands for subsistence. ${ }^{139}$

By enacting interim measures, both parties seemed assured of achieving a form of certainty. ${ }^{140}$ However, these treaties would be preferred by Aboriginal communities since they appeared to be fashioned after the notion of a continuous relationship. Therefore, the methodology preferred by Aboriginal groups denied the government the finality it sought at the time the treaty was signed. In light of the fact that Aboriginal communities had been making treaties amongst other Nations, they did not foresee that uncertainty would arise via failed treaty promises, attempts at assimilation, and/or total disregard for their cultural, spiritual and traditional values and norms.

Chapter 3 will pursue the differing ideologies associated with Aboriginal rights and title by continuing to examine the main court decisions that were instrumental in shaping and defining Aboriginal rights and title in Canada. Furthermore, it will explore the social and political issues that impacted on the achievement of certainty in the settlement of land claims in order that we may understand why certainty, as it is defined today, is problematic for many Aboriginal groups.

\footnotetext{
139 See generally the terms of both Treaty No. 5 and Treaty No. 9, online: Indian and Northern Affairs Canada <http://www.ainc-inac.gc.ca $>$ (date last accessed: 21 January 2006).

${ }_{140}$ However, it should be noted that these cases were few and far between.
} 


\section{CHAPTER 3}

\section{MODERN DAY TREATIES AND CERTAINTY}

In the past 15 years alone, Canadians have witnessed events such as the $\mathrm{Oka}^{141}$, Gustafsen Lake ${ }^{142}$ and Burnt Church ${ }^{143}$ crises, which pitted the federal government and Aboriginal groups against each other over lands, resources and rights. The scenes from these stand-offs will forever be engraved in our memories. Who can forget Oka, where Mohawk warriors $^{144}$ stood face to face with soldiers and police officers, both with weapons in hand, both ready to engage in battle to protect their interests. The violence, frustration, and anger flashed across Canadian televisions on a nightly basis on the six o'clock news. It was these moments that have united a people and divided a nation, highlighting the uncertainty over lands, resources and rights. It was these moments which marked a significant turning point, one that inspired Aboriginal people to adopt an alternative method of 'stand off' in order to be heard.

As an alternative to "armed stand offs", other Aboriginal groups have selected the Canadian legal system in order to have their rights further recognized and defined. This is an ironic twist for both parties, since the courts have historically been slow in acknowledging Aboriginal rights. However, the judicial shift since the 1990s has empowered some The 1990 Oka crisis actually commenced in 1959 when the municipality surrounding Oka began
construction of a golf course. The Mohawk people asserted at that time that the golf course was being
constructed on their traditional territory but were unsuccessful in stopping construction. In 1989, the
municipality announced plans to expand the existing golf course, which resulted in further protests by the
Mohawks. As a result of these protests, the Quebec government entered into negotiations with the
Mohawks that subsequently broke down. On July 11,1990 , after barricades had been set up to stop the
construction, the Mohawks and provincial police officers exchanged gunfire, resulting in an officer's death.
The incident lead to the Royal Commission on Aboriginal People, which will be discussed in Chapter 4 of
this paper, and to date, the golf course has not been expanded.
The Gustafsen Lake crisis took place in 1995 and resulted in the longest criminal trial process with
approximately 21 convictions and 39 acquittals. B. Hughes, "Gustafsen Trial Concludes, Concern Doesn't",
The Peak, vol 96 , issue 5 , June 2,1997 . Gustafsen Lake became the centre of an armed stand off with the Royal
Canadian Mounted Police (RCMP) and participants in a Sun Dance Ceremony who claimed to be defending
sacred Aboriginal ground. The land had been purchased and fenced off by the proprietor, who on past
occasions had allowed the ceremony to take place but on this day he tried to evict the Aboriginal group. The
RCMP was called and shots were exchanged resulting in a death.
The Burnt Church crisis was a result of the 2000 Marshall decision handed down by the SCC that will
be discussed in this chapter. It pitted Aboriginals, non-Aboriginals and the Department of Fisheries and Oceans
officers against each other. Boats were destroyed and gunshots were fired but no one was injured or killed.
144 This was the name that the media dubbed the Mohawk people who were involved in the stand off. 
Aboriginal groups to embrace the very system that once oppressed it. ${ }^{145}$ Since 1992 , INAC litigation has increased ten fold, and in more that $95 \%$ of the cases, INAC is the defendant. ${ }^{146}$ What is most remarkable about this shift is that the irony is not lost on the federal government, who spends approximately $\$ 36$ million on litigation management per year. ${ }^{147}$ In a speech to the Canadian Bar Association, the former Deputy Minister of INAC, Shirley Sarafini stated: "In many ways, the rapid increase in the volume of litigation is eloquent testimony to the value placed on litigation by First Nations and other Aboriginal peoples". 148

This chapter will briefly overlap the timelines set out in the previous chapter, covering the period between 1969 through to 2003. It will explore the political and social issues that were at play during the conception and evolution of the comprehensive land claims negotiation process. This includes an examination of the changes that INAC implemented via its comprehensive land claims policy in order to achieve certainty in relation to land claim settlements, as well as the impacts the Calder and other legal decisions had in connection to future land claims in Canada.

In addition, it will examine the conflicting views that emerged as a result of the 1969 White Paper, the repatriation of the Constitution Act, and the legal challenges that played out during the 1990s. It will also show how these conflicts resulted in subsequent changes to governmental policies and in the relationship between the various parties in the negotiation process. ${ }^{149}$

\footnotetext{
145 This statement is not intended to imply that Aboriginal groups/communities/organizations favour litigation over negotiations or that the courts have always handed down favourable decisions towards Aboriginal people since 1990. Aboriginal people, organizations and academic scholars have been critical of all or aspects of various court decisions during the aforementioned period.

146 Department of Indian Affairs and Northern Development, Canadian Bar Association "Negotiation or Litigation - Which Way Forward?" (Manitoba: 2000). Although confrontations still take place between mainstream authorities and Aboriginal groups, these are minimal compared to the number of cases before the courts.

${ }_{147}$ Indian and Northern Affairs Canada and Canadian Polar Commission 2000-2001 Main Estimates Part III - Report on Plans and Priorities (Ottawa: Public Works and Government Services, 2000). Litigation management includes prevention, readiness and test case funding.

148 DIAND, supra note 136 at 2.

149 The negotiation process encompasses a variety of activities including formal and informal discussions, frameworks, agreement-in-principles, interim measures for land management and participation on land and resource boards, final agreements and implementation management. Parties in the negotiation process include the federal and provincial/territorial governments, Aboriginal groups and third parties.
} 


\section{A. The Birth of Modern-Day Treaties}

"Using the masters' tools to destroy the master's house ${ }^{150}$, reappropriating colonial schemes, converting them into resources for cultural survival, are strategies that oppressed people have honed for centuries."

Prior to the Calder decision, the Liberal government re-examined Aboriginal issues in relation to the overall Canadian governmental structure and societal changes that were taking place. It subsequently responded with an overall action plan - the 1969 White Paper on Indian Policy. ${ }^{152}$ The premise of the White Paper was to terminate treaties, revoke the Indian Act and shift the jurisdiction of reserves from federal to provincial level ${ }^{153}$, thus absolving the federal government of its responsibilities to Aboriginal people as outlined by the division of powers. This new policy position of assimilation was in stark contrast to the position of 'distinct and unique societies' long held by Aboriginal groups. It also contradicted the recommendations of the 1948 and 1961 Joint Committee of the Senate and House of Commons on Indian Affairs that called for the establishment of a claims commission in Canada to examine the Indian land question. ${ }^{154}$ The government argued that it was an attempt to end discrimination against Aboriginal people by affording them the same individual rights as other Canadians. ${ }^{155}$ According to W. Rudnicki, "the intention was to terminate all First Nations quickly and with finality by means of administrative and

\footnotetext{
$150 \quad$ Lordes uses this analogy to describe discrimination and oppressive practices carried out by the dominant culture in society. See, A. Lordes, The Master's Tools Will Never Dismantle The Master's House, in Sister Outsider, (Trumansburg: Crossing Press, 1984) 110- 113.

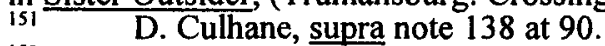

152 At the time the White Paper was issued, Pierre Trudeau was Prime Minister and Jean Chretien was the Minister of Indian Affairs and Northern Development.

153 To transfer jurisdiction of Indian reserves from federal to provincial responsibilities requires an amendment to section 91(24) of the Constitution Act.

${ }_{154}$ Recommendation IX reads: "An Indian Claims Commission should be established to hear the British Columbia and Oka Indian land questions and other nations and that the cost of counsel to Indians for the two land questions specified above, be borne by the Federal Treasury". Canada, Joint Committee of the Senate and the House of Commons on Indian Affairs, (Ottawa: Queen 's Printer and Controller of Stationary, 1961) (Co-chairs: Honourable Senator James Gladstone and Mr. Lucien Grenier, M.P.) at 618. 155 Ibid.
} 
legislative action, by amending the constitution and by establishing full provincial jurisdiction over Indian communities". ${ }^{156}$

The termination policy sparked an insurgence among Aboriginal communities and solidified the National Indian Brotherhood (NIB) (now the Assembly of First Nations) to speak and act on behalf of Aboriginal people throughout Canada. ${ }^{157}$ With Aboriginal issues thrust into the limelight and with much at stake, the NIB seized the opportunity to reassert their notion of treaty and Aboriginal claims and responded with their own paper - the Red Paper - Citizens Plus. ${ }^{158}$ Faced with mass opposition by Aboriginal groups, the federal government shelved the White Paper in 1970, but continued to support the idea of Aboriginal assimilation into mainstream society. In 1972, the Liberal political face once again changed when the party was reduced to a minority government and the two opposition parties were supporting favourable Aboriginal land claim policies.

In 1973, as result of the Calder case, increased political opposition and strong societal support, the federal government announced plans to create a comprehensive land claims policy. The objective of the policy was to provide more of a substantive and balanced

\footnotetext{
156 W. Rudnicki, "Reveille for First Nations: The Politics of Aggression and Defence", (January 1987) The NIB was formed amidst controversy amongst treaty and status First Nations, non-status and the Métis. Past attempts to form a united Aboriginal lobbying group failed largely due to lack of societal support and diverging opinions among Aboriginal groups. Few examples of disbanded groups are League of Nations (1920s), The North American Indian Brotherhood (1940s), and the National Indian Council (1961). The NIB was formed amidst controversy amongst treaty and status First Nations, non-status and the Métis. Past attempts to form a united Aboriginal lobbying group failed largely due to lack of societal support and diverging opinions among Aboriginal groups. A few examples of disbanded groups are the League of Nations (1920s), the North American Indian Brotherhood (1940s), and the National Indian Council (1961). [unpublished, archived at the Library of Indian and Northern Affairs].

157 The NIB was formed amidst controversy amongst treaty and status First Nations, non-status and the Métis. Past attempts to form a united Aboriginal lobbying group failed largely due to lack of societal support and diverging opinions among Aboriginal groups. Few examples of disbanded groups are League of Nations (1920s), The North American Indian Brotherhood (1940s), and the National Indian Council (1961).

is8 The term Red Paper was adopted from the Coolican Report. The Library of Parliament, Aboriginal Rights and Land Claims, (Background Paper) by G. Schmitz (Ottawa: Library of Parliament, 1982). In the 1961 Report to the Senate and House of Commons on Indian Affairs, the joint chairmen [sic] the Honourable Senator James Gladstone and Mr. Lucien Grenier, M.P. noted that "not only from the content of the briefs and submissions made but as well in the quality and manner of presentations, that the winds of change have been blowing through the ranks of Indian people and that there is also a growing awareness and recognition of their problems and needs amongst the non-Indian population". Canada, Joint Committee of the Senate and the House of Commons on Indian Affairs, supra note 154 at 605 .
} 
negotiating process that would produce a long-lasting definition of rights to lands and resources. $^{159}$

While in Calder, the SCC differed on the test for the extinguishment of title, the Government of Canada's policy, In All Fairness: A Native Claims Policy, was conceived as a method to achieve certainty through "blanket extinguishment"160, and for cession and surrender provisions. This notion of blanket extinguishment was similar to the traditional surrender-grant-back style that was used prior to the establishment of modern-day treaties. ${ }^{161}$

In the original policy, the federal government contended that any action on its behalf, prior to the introduction of the policy, could not be taken since:

...Aboriginal title claims were not susceptible to easy or simple categorization; that such claims represented, for historical and geographical reasons, such a bewildering and confusing array of concepts as to make it extremely difficult to either the courts of the land or the government of the day to deal with them in a way that satisfied anyone. Consequently, it was decided such claims could not be recognized. ${ }^{162}$

Subsequently, as the policy developed and evolved, claims were divided into two categories: comprehensive claims and specific claims. ${ }^{163}$ Comprehensive land claims thereby became defined as those claims "based on the concept of continuing Aboriginal rights and title which have not been dealt with by treaty or other legal means". ${ }^{164}$

\footnotetext{
159 Department of Indian Affairs and Northern Development (1993) Federal Policy for the Settlement of Native Claims, Minister of Indian Affairs and Northern Development, Ottawa at I. The term comprehensive was used to denote the variety of rights, such as hunting, fishing, trapping, land, money, that would be protected in exchange for a release of title.

160 Under the 1981 Comprehensive Claims Policy, 'blanket extinguishment' refers to the extinguishment of all land claims based on Aboriginal title in exchange for conferral of specific rights and benefits.

${ }_{161}$ Surrender-grant-back is the process by which Aboriginal people negotiate with the Crown for recognition of specialized treaty rights, in exchange; Aboriginal beneficiaries agree to surrender all of their Aboriginal title to the totality of their traditional territories.

162 In All Fairness, supra note 136 at 11 . [Emphasis added].

163 Department of Indian Affairs and Northern Development (1987) Comprehensive Land Claims

Policy, Minister of Supply and Services Canada, Ottawa.

164 The Federal government has accepted a limited number of claims for negotiation as comprehensive claims in areas affected by treaties. In All Fairness, supra note 136 at I. Specific claims (although not directly addressed in this paper) are defined as those "arising from alleged non-fulfilment of Indian treaties and other lawful obligations, or the improper administration of lands and other assets under the Indian Act or formal agreements". There also exists a third catch-all category referred to as "other claims", which is meant to describe claims that are within the scope of both comprehensive and specific claims yet fail to meet the criteria in order to be categorized as such. To date there are currently three processes under negotiations.
} 
In creating this policy, the federal government embraced the theory that Aboriginal title was equivalent to an Aboriginal interest, which meant that the Government of Canada did not recognize a full Aboriginal title to lands. Instead, it held that traditional use and occupancy of the lands was an interest, deriving from traditional use and occupancy, and was dependent upon the goodwill of the Crown. ${ }^{165}$ As such, the interest could be extinguished as long as compensation was provided. This artifice in terminology created problems since it seemed to denote that there was consensus on the nature and scope of Aboriginal title, rights and resources.

In 1974, the Office of Native Claims (ONC) was created for the purpose of settling comprehensive and specific claims. Initially, the criteria that would have to be met in order for an Aboriginal community to have a claim accepted for negotiations was based on historical accuracy and legal merit. ${ }^{166}$ In 1979, the federal government expanded the criteria by adopting the principles set out in the Baker Lake decision, which are as follows:

1. The claimants and their ancestors were members of an organized society;

2. The organized society occupied the territory over which they asserted Aboriginal title;

3. The occupation was to the exclusion of other organized societies; and

4. The occupation was an established fact at the time sovereignty was asserted by England. ${ }^{167}$

Since the establishment of the CLCP in 1981, the federal government has tried to limit negotiations by only accepting claims that could meet the above noted criteria. ${ }^{168}$ However, even with this limitation, the comprehensive claims process was slow moving.

\footnotetext{
165 Department of Indian Affairs and Northern Development, "Comprehensive Claims Critique and Analysis" (1987) [unpublished: archived at the Library of Indian and Northern Affairs] at II.

166 During my research I failed to come across any explanation of what was meant by the terminology historical accuracy and legal merit.

${ }_{167}$ Baker Lake, supra note 2 at 80 . In this case, the Inuit of the Baker Lake area situated in Northwest Territories sought to have an injunction against further mining and mineral exploration, which was effecting their traditional hunting and fishing territory, based on their Aboriginal right to occupy and use the land. In rendering his decision, Justice Mahoney held that the Inuit had an occupancy based Aboriginal title arising from common law such as the proposition put forth by the $\mathrm{SCC}$ in the Calder case. Although it was deemed that the Inuit met the above mentioned criteria, it was also determined that their Aboriginal title had been extinguished.

${ }_{168}$ There have been exception to this rule such as, the Sahtu Dene Land Claim agreement. The CLCP has twice been amended. These amendments will be discussed later on in this chapter.
} 
This was primarily due to the fact that to deal with the uncertainty of unsettled land claims and to control the amount of compensation paid out annually, the federal government accepted a limited number of claims for negotiations each year. ${ }^{169}$ The situation intensified in British Columbia, which had (and still has) the largest number of unresolved land claims, since the provincial government yet again refused to partake in the negotiation process on the basis that Aboriginal rights and title never existed in the province. ${ }^{170}$ Another significant reason for the slow pace was that Aboriginal groups did not view their rights in terms of claims, especially in light of the past relationship with the Crown:

Even under the Canadian Indian treaties, the oral history of First Nations is that they never agreed to the annihilation of their political existence. They wanted their Indian way of life to continue...They entered into political arrangements, the treaties, only to share the land and resources in order to co-exist peacefully with the settlers and not give up their nationhood..$^{171}$

Furthermore, the AFN stated:

The First Nations of Canada do not view their rights in terms of claims. We more properly view the claims process as one of the few mechanisms available for implementing our constitutionally protected rights. ${ }^{172}$

$\mathrm{K}$. Lochead notes that in the wake of the recognition of Aboriginal title, the CLCP has done very little to improve Aboriginal people's ability to exercise continued title largely due to the cede, release, surrender provisions contained in the final agreements. ${ }^{173}$ Thus, it becomes clear that the negotiation process was initially so slow because Aboriginal groups refused to cede, release and surrender rights and title and the Government of Canada refused to an outright recognition of title at the onset.

\footnotetext{
169 The original guidelines only allowed for one claim to be negotiated in each province or territory at any given time. This resulted in claims being put on a waiting list creating a huge backlog.

170 This despite the fact that the SCC had rejected this argument. D. Culhane, supra note 138 at 91. 171 Continuing Legal Education, "The Inherent Right of Self-Government as an Aboriginal and Treaty Right", (Background Paper) by D. Opekokew, Toronto 1994 vol.2 at 12.

$172 \quad$ AFN, supra note 12 at 9.

173 K. Lochead, "The Political Accommodation of Native Title in Canada and Australia: A Critical Comparative Analysis of Canada's Comprehensive Claims Policy and Australia's Native Title Act", online: CPSA < $<$ ttp://www.cpsa-acsp.ca/papers-2004/Lochead.pdf $>$ (last accessed: 21 January 2006) at 27.
} 


\section{B. Aboriginal rights and the Constitution}

We, the Original People of this Land know the Creator put us here.

The Creator gave us laws that govern all our relationships to live in harmony with nature and mankind.

The laws of the Creator defined out rights and responsibilities.

The Creator gave us our spiritual beliefs, our language, our culture, and a place on Mother Earth which provided us with all our needs.

We have maintained our freedom, our languages, and our traditions from time immemorial.

We continue to exercise the rights and to fulfill the responsibilities and obligations given to us by the Creator for the lands upon which we placed.

The Creator has given us the right to govern ourselves and the right to selfdetermination.

The rights and responsibilities given to us by the Creator cannot be altered or taken away by another Nations ${ }^{774}$

As the constitutional renewal period began in 1978 and continued to 1982, Aboriginal treaty rights were considered to be part of the dynamics in Canadian political life. ${ }^{175}$ However, while the renewal period would prove to be a taxing feat for the provinces, it was especially difficult for Aboriginal groups throughout the country. Initially, the federal government resisted a constitutional provision on Aboriginal rights and treaty rights (deemed the Aboriginal package ${ }^{176}$ ), but after strong opposition on the part of Aboriginal leaders, the government revisited the issues. While Aboriginal leaders may have been successful in thrusting the 'Aboriginal package' into the political realm, the end result was considered less than satisfactory.

On April 17, 1982, amid protest from Aboriginal groups, the Constitution Act was enacted, with the Charter of Rights and Freedoms entrenched shortly thereafter, outlining the rights and freedoms of Canadian citizens. For Aboriginal people across Canada, the

\footnotetext{
$174 \quad$ Petition and Bill of Particulars of the Establishment of Negotiations Between Indian Nations in Canada and the Government of Canada to Resolve Outstanding Differences Prior to the Patriation of the Canadian Constitution. L. Mandell, Creeping Out of the Dark Ages...Slowly, B.C. for Continuing Legal Education, Vancouver Conference, July 1993.

175 J. Magnet, Constitutional Law of Canada, Vol.2, 3rd ed., (Toronto: Carswell, 1987). Canada, under the guidance of Prime Minister Pierre Elliot Trudeau, set out to conceive a new country that would see rights and freedoms for all Canadians defined under a revised Constitution.

${ }_{176}$ T.S. Palys, "Prospect for Aboriginal Justice in Canada", online: sfu

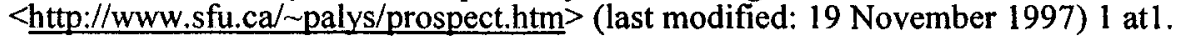


Constitution articulated two new important sections that directly dealt with indigenous and treaty rights. These were section $25^{177}$ and $35^{178}$ of the Constitution Act.

From an Aboriginal perspective, the Constitution has created a considerable amount of uncertainty as it is silent on the nature and scope of Aboriginal rights ${ }^{179}$. Many Aboriginal groups felt that the Constitution Act did not provide enough protection. However, today the Constitution plays an important role in land claims settlements, since all settled land claims are protected under s.35, where Aboriginal rights are 'recognized and affirmed'. They are protected insofar as there is a basis on which other Charter provisions might be invoked in order to balance off the effect of the treaties. ${ }^{180}$ This has resulted in a greater level of certainty because once a modern-day treaty is enacted it is Constitutionally protected, and

\footnotetext{
$177 \quad$ "The guarantee in this Charter of certain rights and freedoms shall not be constructed so as to abrogate or derogate from any Aboriginal, treaty or other rights or freedoms that pertain to the Aboriginal peoples of Canada including

(a) any rights of freedoms that have been recognized by the Royal Proclamation of October 7, 1763, and

(b) any rights or freedoms that now exist by way of land claims agreements or may be so acquired."

B. Reesor, The Canadian Constitution in Historical Perspective, (Scaraborough: Prentice-Hall, 1992). Section 25(b) became a major source of contention and was eventually changed in the 1983 Constitutional Amendment Proclamation, and from: any rights or freedoms that may be acquired by the Aboriginal peoples of Canada by way of land claims settlements. [Emphasis added]. Another important provision was section 37 which "provided for a First Ministers' Conference to which representatives of the Aboriginal groups would be invited". It was at this conference that the decision to change 25(b) was made and then altered in the 1983 Constitution Amendment Proclamation. It is also of interest that while section 25 may have preserved the original collective rights of Aboriginal peoples from the dilution by individual rights, it did not create any new rights.

178 The second and main provision pertaining to Aboriginal peoples is entrenched in section 35, Part II of the Constitution Act, 1982, and notes some of the land claim rights of the Canadian Aboriginal peoples. Section 35 (1) The existing Aboriginal and treaty rights of the Aboriginal peoples of Canada are hereby recognized and affirmed. (2) In this Act, 'Aboriginal peoples of Canada' includes the Indian, Inuit and Métis peoples of Canada.(3) For greater certainty, in subsection (1) 'treaty rights' include rights that now exists by way of land claims or may be so acquired. Ibid.

(4) Notwithstanding any other provision of this Act, the Aboriginal and treaty rights referred to in subsection (1) are guaranteed equally to male and female persons. Ibid. at 382.

179 It has been argued by Aboriginal people and academic scholars that the word "existing adds nothing to section 35(1), since it was never intended to revive Aboriginal or treaty rights which had been legally ended in the past". A. Bayefsky and M. Eberts, Equality Rights and The Canadian Charter of Rights and Freedoms, (Toronto: Carswell, 1985). It was also noteworthy that the rights outlined in section 35 are not subject to limitation by section 1 or to the section 33 override provision because they fall outside of the Charter of Rights and Freedoms. While exclusion from section 1 and 33 may seem advantageous, any violation of rights in section 35 cannot provoke remedies under section 24 , the enforcement provision. There is also a third provision, in relation to Aboriginal peoples, which references section $91(24)$ of the Constitution Act, 1867 which as previously stated, assigned exclusive legislative authority over Aboriginal peoples, and lands reserved for Aboriginals to the Federal government 180 It must be noted that although all comprehensive land claim agreements receive constitutionally protection, not all self-government agreements are constitutional protected.
} 
it is "generally recognized that Aboriginal and treaty rights are protected from unilateral extinguishment". ${ }^{181}$

\section{Changes to the Comprehensive Claims Policy (Post - Constitution)}

After the addition of section 35 into the Constitution, Aboriginal groups became increasingly dissatisfied with the federal government's comprehensive land claims policy. ${ }^{182}$ Following a tumultuous period of dialogue with Aboriginal groups, the federal government revised the policy in 1986, broadening the breadth of comprehensive claims negotiations and providing an alternative to blanket extinguishment. ${ }^{183}$ The basic principle of the amended policy stated: "To obtain clarity and certainty regarding use and disposition by government of crown lands and resources". ${ }^{184}$ Other changes included the removal of blanket extinguishment as a condition of settlement, the participation of provincial and territorial governments, protection of third party interests, and broader scope of issues that could be negotiated. ${ }^{185}$

The thrust of the amended comprehensive land claims policy thereby allowed for the retention of Aboriginal rights on land which Aboriginal communities would hold following the conclusion of a claim settlement. ${ }^{186}$ The federal government also eliminated the previous six-claim limit on the number of negotiations which could be undertaken at one time. These expanded criteria were meant to provide for a higher degree of certainty in the extinguishment provisions, promotion of federal and third party interest, complexity of submission process in order to have a claim accepted, backlog of claims waiting to be negotiated, control by department of funding support, lack of provincial involvement. AFN, "Doublespeak of the 90's: A Comparison of Federal Government and First Nation Perception of Land Claims Process" (1990) online: ubcic $\langle$ http;//www.ubcic.bc.ca/doubletalk.htm> (last modified: unknown).

183 DIAND, supra note 159 at 1.

184 DIAND, supra note 159 at Summary of Land Claims Cabinet Document [Emphasis Added]. $185 \quad$ Ibid.

$186 \quad$ As well as allowing for the negotiation of self-government agreements in conjunction with comprehensive land claim agreements; resource revenue sharing; environmental management; offshore wildlife harvesting; intenim measure and implementation plans. DIAND, supra note 159 at 14 . However, it should be noted that this retention takes place to the extent that such rights are not contradictory with the settlement agreement. Implementation plans outlining each party's obligations must now accompany the Final Agreement. After a revision of the Comprehensive Claims Policy in 1986, Canada now requires that an implementation plan be annexed to the final agreement that states what activities will be undertaken (and by whom) in order to fulfill the obligations set out in the agreements.
} 
final settled agreement by including the provincial and territorial governments as partners at the negotiation table, as well as allowing for the protection of third party rights.

In addition, two new terms "clarity and certainty" where also inserted into the revised policy. The government now maintained that in settling an agreement, certainty, predictability and finality would be achieved for all parties involved in the settlement. ${ }^{187}$ The NIB and other Aboriginal groups complained that the revision did nothing more than mark a subterfuge in terminology. In 1993, under heavy criticism, the federal government went on the defensive and disputed the notion that negotiated claims settlements were conducted to end or extinguish Aboriginal rights. ${ }^{188}$ In doing so, the federal government reiterated that the purpose of the final negotiated settlement was to provide certainty and clarify rights to ownership, use of land and resources. ${ }^{189}$ The finality aspect sought by the government was simply the 'finality' that rights and obligations for all parties were clearly spelled out and it was explicitly tied to the surrender provisions, and was not meant as a means to end the federal government's and Aboriginal peoples' relationship.

Nonetheless, Aboriginal groups/organizations continued their criticism that certainty was nothing more that the federal government's attempt to assimilate Aboriginal people by severing their connection to the land. On June 2, 1988, the AFN mandated the National Chief to deal with the issue of extinguishment by not accepting it as a means to settle land claim agreements. ${ }^{190}$ This sentiment was echoed again in 1992 
when the AFN adopted another resolution "to advocate the elimination of the extinguishment... and to ensure settlement provisions are deemed to be supplemental to existing Aboriginal and Treaty Rights." 191

\section{The Legal Battles}

"Canada has held the racist view that Aboriginal people are primitive and are incapable of political, legal, historical, or economic thought... Canada has put a lot of energy towards making sure Aboriginal people never get involved in the development of legal principles of Aboriginal rights and title, especially in the courts and in parliament.

The patriation of the Constitution Act created discrepancies and left section 35(1) ambiguous and largely undefined. ${ }^{193}$ By not clearly defining s 35(1), the task was left up to the courts to interpret and articulate what the government was attempting to achieve by this piece of legislation. Conversely, the 1990s sparked a resurgence of Aboriginal rights and title litigation.

In the 1990 R. v. Sparrow ${ }^{194}$ case, the SCC emphasized that the Crown must demonstrate a "clear and plain" intention to extinguish Aboriginal rights and title. ${ }^{195}$ The Court also found that there is a fiduciary relationship between the Crown and Aboriginal peoples based on the need for the Crown to act honourably. Therefore, section 35 must be interpreted in a manner consistent with this relationship. ${ }^{196}$ The SCC placed a high burden on the Crown to justify any infringement against the enjoyment of

\footnotetext{
Assembly of First Nations, (1995) "Extinguishing Extinguishment: Bringing an Era to an End", A Declaration Presented to the Hon. Alvin J Hamilton [unpublished, archived at the Library of Indian and Northern Affairs]. Musqueam band, situated in British Columbia, was charged under the Fishery's Act for using a drift net contrary to section 61(1) of the Act. The Sparrow case involved the use of lands and dealt with many of the Aboriginal rights issues that the Court had been struggling with for years, and also perceived to be at "stake in this appeal". In addressing the meaning of the word 'existing' in relation to rights set out in s.35(1), the SCC noted three important tenets in relation to 'existing' rights: the term is to be applied to those rights that existed when the Constitution Act came into effect but it did not revive extinguished rights. 195 Ibid. At 28-2 [Emphasis added].

196 The first area the court looked at was the meaning of 'recognized and affirmed'. It was the opinion of the majority that a "generous, liberal interpretation of the words in the constitutional provision" be applied to each case and that these rights were not absolute. Ibid. at 28-10.
} 
Aboriginal rights protected by section $35 .{ }^{197}$ The ruling was also significant "because it placed the burden of proving extinguishment on the federal government" as opposed to Aboriginal groups. ${ }^{198}$

The Sparrow case provided greater legal certainty by: defining existing rights to be those non-extinguished rights; establishing an infringement test, noting when the extinguishment of existing rights can take place and that the intent must be made plain and clear; and clarifying a right to fish on lands deemed to be ancestral territory.

Under this ruling, prior to 1982, Aboriginal title could be extinguished and infringed by either voluntary surrender via treaties or infringed by federal legislation demonstrating a 'clear and plain' intent to extinguish and infringe Aboriginal title. To the latter, M. Asch and N. Zlotkin ascertain that "the notion of extinguishment by unilateral action is based on the presumption that prior to the passage of the Constitution Act, 1982, Parliamentary acts represented the supreme law of Canada". ${ }^{199}$

After the ruling, any Aboriginal title, post 1982, could only be extinguished by voluntary surrender. However, title could be infringed upon, but not extinguished, under federal or provincial legislation as long as it was in keeping with the justification test set out by the court. ${ }^{200}$

The AFN argued that the Sparrow decision meant that the Government of Canada must "abandon its illegal 'supersession by law' concept as grounds for

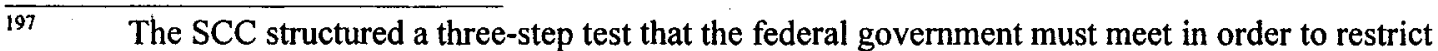
Aboriginal or treaty rights: Is there an existing Aboriginal or treaty right involved?; Has the Aboriginal or treaty right been infringed?; and Is the legislation justified? The onus of proving justification for restrictive regulation remained with the government, and that any infringement would only be valid if it could satisfy the test as set out above.

${ }_{198}$ G. Slowely, supra note 33 at 8.

199 M. Asch and N. Zlotkin "Affirming Aboriginal Title: A New Basis for Comprehensive Claims Negotiation" in Aboriginal and Treaty Rights in Canada: Essays on Law, Equality and Respect for Differences, edited by M. Asch (Vancouver: UBC Press, 1997) at 208.

200 The three-step test that the federal government must meet in order to restrict Aboriginal rights or treaty rights is as follows:

(1) Is there an existing Aboriginal or treaty right involved?

(2) Has the Aboriginal or treaty right been infringed?

(3) Is the legislation justified?

The onus of proving justification for restrictive regulation remained with the government, and that any infringement would only be valid if it could satisfy the test as set out above. K. Lochead, supra note 173 at 21.
} 
extinguishment." ${ }^{201}$ However, as G. Slowely notes, the Sparrow ruling "pointed out the necessity for the government to ensure clear surrender was obtained". ${ }^{202}$ The ruling also prompted INAC to once again amend its criteria that an Aboriginal group must demonstrate in order to have a claim accepted. ${ }^{203}$ For Aboriginal groups, this meant that the government would be unwilling to negotiate any agreement that did not contain the cede, release or surrender clause.

In 1996, the Supreme Court once again dealt with the issue of 'existing Aboriginal rights' and the notion of rights being 'integral to distinctive culture' in the Van der Peet ${ }^{204}$ case. The SCC decided that an Aboriginal group must establish that, at time of contact with Europeans, the particular activity claimed as an Aboriginal right was a practice, tradition or custom, and was integral to the society's distinctive culture; Aboriginal rights have to be given priority but they also have to be reconciled with other rights and interests.

On December 11, 1997, in the landmark decision of Delgamuukw v. The Queen ${ }^{205}$, the SCC clarified the connection between Aboriginal rights and land...by noting "that Aboriginal rights lie along a spectrum in regards to their relationship to land". ${ }^{206}$ In

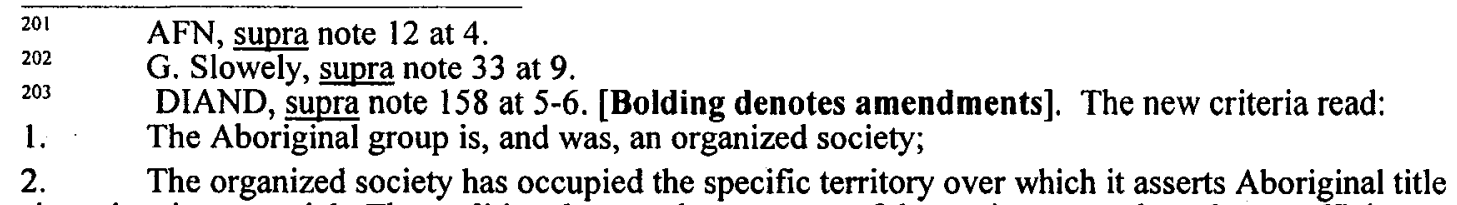
since time immemorial. The traditional use and occupancy of the territory must have been sufficient to be an established fact at the time of assertion of sovereignty by European nations;

3. The occupation of the territory by the Aboriginal group was largely to the exclusion of other organized societies;

4. The Aboriginal group can demonstrate some continuing current use and occupancy of the land for traditional purposes;

5. The group's Aboriginal title and rights to resource use have not been dealt with by treaty;

6. Aboriginal title has not been eliminated by other lawful means

${ }_{204}$ R. v. Van der Peet, [1996] 2 S.C.R. This case focussed on the question of whether s.35 of the Constitution Act, 1982 included, as an Aboriginal right, a right to fish commercially.

${ }_{205}$ In this case, the Hereditary Chiefs of Gitksan and Wet'suwet'en people, as a collective, were claiming full ownership rights in regard to over 58,000 square miles of land west of British Columbia. The Crown argued that Aboriginal rights were extinguished when they accepted and used the reserve system detailed in the Indian Act. Delgamuukw, supra note 2.

206 "Group Rights: Collective Bargaining and Aboriginal Rights" in D. Elliot and R. Warskett, Introduction To Public Law, $4^{\text {th }}$ Ed., (North York: Captus Press Inc., 1999) at 258. 
deciding the Delgamuukw case, the SCC attempted to put an end to the 'uncertainty' surrounding rights and title by addressing seven essential points. ${ }^{207}$ The seven points are: oral history ${ }^{208}$; Aboriginal Title; Proof of Aboriginal title; Extinguishment of rights and title; Infringement; Negotiation; and Self-Government. ${ }^{209}$

In dealing with the question of Aboriginal title, the $\mathrm{SCC}$ recognized an Aboriginal title at common law based on 'original and continuous occupation' and use by particular Aboriginal people. This signified that Aboriginal people were no longer deemed 'tenants at will' but instead were now legal possessors. According to the court:

...Aboriginal title is sui generis ${ }^{210}$, and so distinguished from other proprietary interests, [most notably fee simple] and characterized by several dimensions. ${ }^{211}$

The court therefore applied a broad right to Aboriginal groups that went beyond the right of carrying out traditional practices and included a right to resources situated on the land, which reversed the decisions handed down in the Baker Lake case. The only limitation placed on the context of title was that the land cannot be used in a way that destroyed the people's relationship to the land, as noted in the Van der Peet case. ${ }^{212}$

\footnotetext{
$207 \quad$ All of the seven points had been dealt with, in one way or another, in previous legal litigation. 208 In approaching the first issue of 'oral Aboriginal history', the Court stated that "Aboriginal rights are truly sui generis and demand a unique approach to the treatment of evidence which accords due weight to the perspective of Aboriginal people". In articulating this point, the court accepted Chief Delgamuukw's opening statement and noted the importance of accepting into evidence the oral history surrounding Aboriginal cases. This marked a significant departure from the court's traditional stand of 'oral history' as hearsay evidence and therefore not admissible in court. However, Lamer C.J. also stressed that some accommodation must take place in affording oral history its place in the legal realm, as not to allow it to "...strain the Canadian legal and constitutional structure..." Delgamuukw, supra note 2 at 1011 . According to the Duhaime Law Dictionary hearsay is defined as "Any evidence that is offered by a witness of which they do not have direct knowledge by, rather, their testimony is based on what others have said to them. The basic rule, when testifying in court is that you can only provide information of which you have direct knowledge. In other words, hearsay evidence is not allowed. Hearsay evidence is also referred to as 'second-hand evidence' or as 'rumour'. You are able to tell a court what you heard, to repeat the rumour, and testify that, in fact, the story you heard was told to you, but under the hearsay rule, your testimony would not be evidence of actual facts of the story but only that you heard those words spoken." Duhaime's Law Dictionary, online <http://www.duhaime.org/dictionary/dict-gh.htm\#H> (Last modified: unknown). examined. Note for the purpose of this paper, the issue of self-government will not be presented and/or

210 In 1984, the SCC purported a special relationship by the Crown and a common law recognition of occupancy based rights in the landmark case of Guerin v. $R$. The decision that was based on the sui generis (truly unique) nature of Aboriginal interests in Aboriginal title and the implicit commitments in s. 37 and 38, along with the surrender provision of the Indian Act effectively declared the Crown bound by a fiduciary duty.

211 Delgamuukw, supra note 2 at 1012.

212 This limitation was to ensure, for example, that an Aboriginal hunting ground cannot be destroyed by being turned into a shopping centre, parking lot, etc, allowing for traditional enjoyment of the land.
} 
In their analysis of Aboriginal title, the SCC rejected the arguments put forth by the Crown, instead purporting a notion of 'exclusive occupation' which stated that:

...Aboriginal title encompasses the right to exclusive use and occupation of land; ...the right to choose to what uses land can be put [with the exception of the above mentioned limitation]; ...lands have an inescapable economic component... ${ }^{213}$

With respect to the issue of proof of Aboriginal title, the SCC conceived that there were two major distinctions under the test for Aboriginal title:

[First] the requirement that the land be integral to the distinctive culture of the claimants is subsumed by the requirement of occupancy; [and second], whereas the time for identification of Aboriginal rights is the time of first contact, the time for the identification of Aboriginal title is the time at which the Crown asserted sovereignty over the land. ${ }^{214}$

In deciding the capacity of a province to extinguish Aboriginal title, the Court found that provinces do not have any legal jurisdiction to extinguish Aboriginal title. ${ }^{215}$ The court, in determining the issue of extinguishment, reaffirmed the test set out in Sparrow, i.e., the intent of extinguishment must be made 'clear and plain' by the Crown. Moreover, as M. Stevenson points out the Delgamuukw ruling held "as a matter of law, extinguishment does not result in the absolute certainty that was expected", on the contrary, "extinguishment gives rise to fiduciary obligations". 216

In relation to infringement, the SCC yet again reiterated their position in Sparrow by concluding that the government may infringe on Aboriginal title, but must justify any infringement. An infringement that does take place by the government must also be properly and equitably compensated for. The Court concluded that the best way for the government and Aboriginal groups to resolve their differences was through the

\footnotetext{
$213 \quad$ Ibid. An inescapable economic component in relation to Aboriginal title allows for Aboriginal groups to seek compensation by the federal or provincial governments for land use which infringes on Aboriginal title.

214 Ibid.

215 Ibid. The Crown argued that Aboriginal title was extinguished based on the following three theories: a) blanket extinguishment; b) title was extinguished through the establishment of Indian reserves, as well as the fact that Aboriginal peoples were living on these reserves; or c)Through the creation of land grants by the Province. Assembly of First Nations, Material on Canada's Comprehensive Claims Policy, [unpublished, archived at the Library of Indian and Northern Affairs].

Stevenson, supra note 13 at 122 .
} 
negotiation process. To emphasize this point, Lamer C.J. stated "the Crown is under a moral, if not a legal, duty to enter into and conduct those negotiations in good faith...Let us face it, we are all here to stay". 217

In 2000 , the SCC rendered yet another decision involving treaty rights, $R v$. Marshall. ${ }^{218}$ The negative impact from this case proved to be one that would put the political and legal concept of certainty to the test. The SCC stated that interpreting treaties must take into consideration not only the wording involved, but the historical and cultural context as well. Expanding on the decision in Simon ${ }^{219}$, and upholding their decision in Sparrow, the SCC reaffirmed that existing treaties were subject to legislative restrictions on justifiable grounds. In the Marshall case, the Court found that an existing treaty right did exist under the 'truck house' ${ }^{220}$ clauses, allowing hunting, fishing, gathering and vending rights arising from a Peace and Friendship Treaty, but was limited to securing a 'moderate livelihood'.221

The SCC reaffirmed that treaties have a degree of certainty that must be maintained, whether they were signed yesterday or hundreds of years ago. This meant that the government must fulfill/implement their commitments by honouring treaties or extinguishing them in the appropriate legal manner. The response to the Marshall

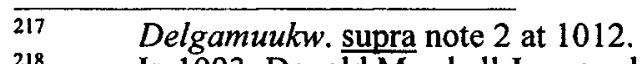

218 In 1993, Donald Marshall Jr. was charged with three counts under the Fisheries Act, relating to fishing eels out of season. After the trial judge and the Nova Scotia Court of Appeal found him guilty, the appellant appealed to the Supreme Court of Canada. On September 17, 1999, the Supreme Court acquitted Marshall on all charges.

219 Simon v. The Queen, [1985] 2 S.C.R. 387 [hereinafter Simon]. Mr. Simon was prosecuted by the Attorney General Nova Scotia for hunting contrary to the applicable Nova Scotia wildlife legislation. In his defence, Mr. Simon cited the Treaty of 1752 between British Columbia and his ancestors. Nova Scotia argued that the treaty had been extinguished in the two hundred years since its creation. The SCC ruled that the Crown failed to prove the termination of the treaty. Therefore, Mr. Simon could benefit from its terms on hunting rights. The Court indicated its willingness to enforce treaty provisions, even where they have not been strenuously enforced for decades or even centuries, and placed a heavy burden on the Crown to show that treaty rights were extinguished by laws of general application.

${ }_{220}$ "A truck house was a trading post established by the British authorities, and these clauses were promises by the Indians to trade with the British rather than the French." See T. Flanagan, First Nations? Second Thoughts, (Montreal: McGill University Press, 2000).

West Nova Fishermen's Coalition (an intervener) applied for a rehearing of the appeal, a stay of the judgement, and a further trial to decide the sole issue of "whether the application of the fisheries regulations to the exercise of a Mikmaq treaty right could be justified on conservation or other grounds". On November 17, 1999, the Supreme Court dismissed the Coalition's application and clarified their position in the September 17, 1999 decision. Marshall supra note 2 at 553.
} 
decision was received by both the general public and the media with extreme negativism. ${ }^{222}$ The confrontations and violence in the wake of the Marshall decision only served to highlight the uncertainty that existed, in particular to commercial fishing operations, the ability of Aboriginal peoples to exercise their treaty rights, the rights of the general public, existing third-party interests, and the right of the Department of Fisheries and Oceans (DFO) to issue valid and enforceable permits, licences and title.

In an attempt to resolve the outstanding issue and to restore legal and political certainty, the federal government announced plans in January 2001 to restart the treaty negotiation process with Aboriginal groups in New Brunswick, with the objective of finding long-term solutions to issues of Aboriginal and treaty rights. ${ }^{223}$ To date, this work remains ongoing.

In 2003, two Métis hunters challenged the notion of Aboriginal rights. The Powley ${ }^{224}$ case, like the Marshall case, impacted on the notion of certainty. ${ }^{225}$ The difference was that this case raised the issue of whether members of the Métis community in and around the Sault Ste. Marie area enjoy a constitutionally protected right to hunt for food under the s. 35 of the Constitution.

For the federal government, the idea of the Métis having Aboriginal rights, below the $60^{\circ}$ parallel, contradicted INAC's mandate - to create a better quality of life for First

\footnotetext{
222 As confrontation between Aboriginal and non-Aboriginal peoples escalated, the federal opposition called on the government to suspend the Supreme Court's ruling.

${ }_{223}$ B. Roberts "Federal Government wants to start talks about treaty rights" Transcript from Information Morning Radio Fredericton CBZ-Am (01 January 2001) Reference \#3173-10B-170808. Also see, B. Underhill, "Memo warns of native, non-native conflict risk" The Chronicle-Herald (17 January 2001) A3.

${ }_{224}$ R. v. Powley [2003], 2 S.C.R. 207

225 The facts of the case were presented to the lower courts as such: In October 1993, Steve and Roddy Powley shot and killed a moose without a hunting licence outside their hometown of Sault Ste. Marie, Ontario. Immediately after killing the animal, the father and son tagged the moose's ear with a hand written tag denoting the time the animal was shot, the date, and place where they killed the animal, and the ammunition used to kill it. On the tag, Steve Powley clearly wrote "meat for the winter my (Ontario Métis Aboriginal Association) number is 4-088-1-0460", and signed his name. The respondents were charged with unlawfully hunting a moose without a hunting licence and with knowingly possessing game hunted in contravention of s. 46 and 47(1) of Ontario's Game and Fish Act.
} 
Nations, Inuit and Northerners. ${ }^{226}$ As such, it was not surprising when the federal government argued that Métis people did not exist before European contact and therefore should not be granted Aboriginal rights. It was the 'pre-contact' criterion, contained in the CLCP, that had excluded the Métis from entering into the negotiation process with the Government of Canada.

The SCC addressed this position by noting:

...the inclusion of the Métis in s.35 is not trackable to their pre-contact occupation of Canadian territory. The purpose of s.35 as it relates to the Métis is therefore different from that which relates to the Indians or the Inuit. The constitutionally significant feature of the Métis is their special status as people that emerged between first contact and the effective imposition of European control. The inclusion of the Métis in s.35 represents Canada's commitment to recognize and value the distinctive Métis cultures, which grew up in areas not yet open to colonization, and which the framers of the Constitution Act, 1982 recognized can only survive if the Métis are protected along with other Aboriginal communities. 227

The SCC held that an Aboriginal site specific right existed in this case and may exist in other Métis communities, but would have to be determined on a case by case basis. Instead of laying out a concrete test for defining Métis under s.35, the Court noted three broad tenets: self-identification, ancestral connection and community acceptance.

The recognition of rights of the Métis people as a distinctive people having distinctive rights in the Constitution has become a concern for INAC. With issues of overlapping claims among claimant groups increasing, concerns over an increased pressure on limited resources, access to rights, resource management and how to address these concerns to ensure that everyone's interests are heard has resulted in greater uncertainty. Despite the fact that Aboriginal leaders across Canada congratulated the

\footnotetext{
$226 \quad$ INAC, supra note 147 at 10. "INAC's core responsibilities with respect to Aboriginal people are primarily related to Status Indians living on reserve and Inuit. In the North, INAC works in cooperation with Inuit and other Aboriginal communities to develop governance structures and to finalize and implement land claims and self-government agreements. Given the unique context of Canada's north, and in accordance with the federal policy on Aboriginal self-government, some agreement also include Métis north of $60^{\circ}$ latitude".

$227 \quad$ Powley, supra note 224 at para 17.
} 
Métis on their victory, it cannot be denied that politically, this may have not been in other Aboriginal groups' best interests. With a claims process that has been highly criticized as slow moving, the process may become more stagnant as Métis claims are potentially accepted into the comprehensive claims and self-government negotiation process. ${ }^{228}$

In light of the fact that the decision was only handed down in September 2003, and the federal government and Métis people are in the early stages of consultation, much remains to be seen as to how certainty can be achieved without further burdening a process that is considered less than ideal. ${ }^{229}$

\section{E. Summary of Modern-Day Treaties and Certainty}

The late 1960s to the 1980s saw the federal government and the Supreme Court of Canada struggle with the concept of Aboriginal title and rights. The solutions varied from attempted assimilation of Aboriginal people into mainstream society to the introduction of a Comprehensive Land Claim Policy in which Aboriginal groups could enter into negotiation with Canada. While the solutions went from one extreme to the next, the colonial structures in which they operated remained the same.

The struggles and inequalities that have plagued Aboriginal groups in an effort to gain cultural and social status continue to be an ever-present force. With a multitude issues, ranging from cultural preservation to land rights, the solutions are just as complex as the issues themselves. In recent years, some Aboriginal groups have adopted the courts as an alternative method in 'standing off' against the federal government, which has brought about mixed results. Litigation as a method of resolving disputes between

\footnotetext{
228 In July 2004, the Métis of Ontario and the provincial government reached a deal that would give Métis similar rights, as those currently exercised by First Nation and Inuit peoples, to hunt and fish out of season and without a licence. "Deal lets Ontario Métis hunt, fish freely", CBC.CA (8 July 2004) online: $<$ http://www.cbc.ca/stories/2004/07/08/canada/Metis hunting040708> (last modified: 8 July 2004). Furthermore, in July 2004, Andy Mitchell, the Minister of Indian and Northern Affairs, was appointed as Minister for INAC and the Federal Interlocutor for Métis and Non-Status Indians. This is the first time since its creation in 1985 , that both positions have been held by the same Minister.

${ }_{229}$ INAC has entered into negotiations with Métis in the NWT under unique circumstance, largely due to the fact that Métis and First Nations have co-existed within the territory.
} 
the differing parties in the negotiation process has often been the source of, or served as, the driving force behind the development of key federal policies, as well as clarifying and achieving recognition of Aboriginal rights and title, as noted in Calder and Delgamuukw.

While it cannot be denied that great strides and advances with regard to Aboriginal rights and title have been made, as a result of recent court decisions, these decisions are not without their own set of problems. For example, in relation to the burden of proof with regard to extinguishment resting with the Crown, the federal government continued its pursuit to seek certainty by ceding, releasing and surrendering any rights that were not contained in the negotiated treaty. Furthermore, the fallout from the Marshall case reiterated a need for certainty in relation to Aboriginal rights in an effort to avoid loss of economic opportunity for both Aboriginal and non-Aboriginals, as well as various third parties.

Furthermore, while certainty was, and is, being sought by both parties, its very definition took on completely different meanings for Aboriginal groups and the federal government. The differing views on the scope and nature of Aboriginal title and rights, the establishment of the comprehensive land claims negotiation criteria, use of extinguishment, surrender and ceding provisions have lead to conflict and reinforced the uncertainty that exists in trying to resolve land claims.

Chapters 2 and 3 have shown that since European contact the true nature of Aboriginal rights and title has not always been so clear. These chapters have also demonstrated that attempts to achieve certainty, that respect the interests of all parties have been unsuccessful and often pitted Aboriginal groups and Crown against each other. Chapter 4 will explore the various task forces, committee and commissions that were created to deal with the differing views with regard to Aboriginal title, rights and the treaty-making process from 1983 to present day. Furthermore, it will explore any recommendations or findings that explicitly dealt with the issues of certainty and 
subsequent action taken on the part of federal government to respond to the recommendations. This examination will be useful to help build a new model of certainty by extracting any commonalities that may exist between the negotiating parties. 


\section{CHAPTER 4}

\section{WRITING THE PATH TO CERTAINTY: ALTERNATIVE MODELS}

Chapter two and three show that various processes, such as negotiating and signing treaties and litigation, were, and still are, important mechanisms in attempting to achieve certainty for both Aboriginal beneficiaries and the federal government. What is not so clear however, are the models deployed to obtain certainty within the treaty making process. On the one hand, Aboriginal groups view the treaty process as a means of securing a permanent living relationship which allows for the recognition of title, access to lands and resources, protection of rights, culture and language, and measurable results. On the other hand, the federal government has sought clarity, predictability and finality through the ceding, surrendering and modification of title and rights, thus resulting in a contractual-like relationship.

The different perspectives on the scope and nature of Aboriginal title and rights, coupled with disagreements over the best method to achieve certainty (e.g. legal process versus an objective-based process versus a holistic process) have resulted in an evergrowing dissatisfaction, which in turn has lead to a number of 'stand offs', and to an increase in litigation by Aboriginal groups as mechanisms for redress. As a means of addressing the mounting discontent and complexity of the issues, the federal government established a number of task forces and commissions in the 1980s and 1990s to investigate the issues and make recommendations.

From 1983 to 1995, five separate reports were produced by an array of task forces, committees or commissions, who were established to review the treaty-making process in various fashions. The first report Indian Self-Government in Canada, 1983 (known as the Penner Report, named after its chair) dealt with the issue of Aboriginal self-government. The second report, Living Treaties: Lasting Agreements, Report of the Task Force to 
review the Comprehensive Claims Policy, 1986 (known as the Coolican Report, named after its chair), as the title suggests, examined the Comprehensive Land Claims Policy. The third was an interim report released by the Royal Commission on Aboriginal People (RCAP), Extinguishment of Rights of Aboriginal Peoples: Problems and Alternatives, 1995, which explored the early policies, legislation and court cases as they related to extinguishment and surrender of rights and title. The fourth, Canada and Aboriginal Peoples: A New Partnership, 1995 (known as the Hamilton Report, named after its chair) noted the varying perspectives of Aboriginal peoples, governments and third parties in the treaty-making process, and included an alternative model of certainty based on the notion of mutual assurance. The fifth, as a direct result of the 1990 Oka Crisis, was another Royal Commission report; The Royal Commission on Aboriginal People released in 1996, consisting of 5 volumes and totalling approximately 4,000 pages, was the most comprehensive examination of Aboriginal issues to date. ${ }^{230}$

This chapter is meant to provide an overview of the anomalies in the treaty making process, and highlight the commonalities among the reports, including the perspectives of the parties involved in the negotiation process. It will examine the aforementioned task force, commissions, etc., along with various academic research on the social and economic issues facing Aboriginal communities. It will also lay the foundation in order for the alternative models suggested to be examined against settlement agreements, and those aspects which may be used in building a new model.

\footnotetext{
230 In 1991, RCAP was mandated to: "investigate the evolution of the relationship among Aboriginal Peoples, the Canadian government and Canadian society as a whole... [and] propose specific solutions, rooted in domestic and international experience, to the problems which have plagued those relationships and which confront Aboriginal People today". RCAP, supra note 1 at vol.1 p 2
} 


\section{A. Commissions, Fact Finders and Task Forces}

"History has shown that agreements with Aboriginal groups in North America are final only when they work satisfactorily". 231

In 1983, the Parliamentary Committee on Indian Self-Government released its findings and recommendations on the establishment of Indian Self-Government in Canada, referenced as the Penner Report. ${ }^{232}$ With approximately $600+$ Aboriginal communities in Canada, primarily existing under the Indian Act, the committee was given the task of examining what models or systems of Aboriginal self-government could exist within the current Canadian legal, political, social and economic environment. ${ }^{233}$ The committee heard testimony from Aboriginal groups across Canada on various aspects of Aboriginal self-government. ${ }^{234}$ Repeatedly, Aboriginal groups voiced their concerns over the nature of the relationship between Aboriginal people and the government, recognition of title and the ability of Aboriginal groups to control their own lands and resources. Throughout their testimony, Aboriginal groups echoed the position that the first step had to be the recognition of Aboriginal title and the right of Aboriginal self-determination by the federal and provincial government by noting "our Aboriginal Title and our right to self-determination are rights we have not and will not surrender". 235

The committee acknowledged that the current relationship between Aboriginal people and the government was not working and strongly recommended that Aboriginal people should and must control their own affairs. It further acknowledged that there was

\footnotetext{
231 Canada, Task Force to Review Comprehensive Claims Policy, Living Treaties: Lasting Agreements, Report of the Task Force to review the Comprehensive Policy, (Ottawa: Department of Indian Affairs and Northern Development, 1985) at 35. [Hereinafter Coolican Report].

232 While the Parliamentary Committee was to look at self-government, repeatedly the issue of extinguishment came up throughout the hearings and thus could not be ignored. Canada, Parliamentary Task Force on Indian Self-Government, Indian Self-Government in Canada, (Ottawa: Department of Indian Affairs and Northern Development, 1983) at 8. [Hereinafter Penner Report]

${ }_{233}$ At the time the report was released only 2 modern day treaties had been signed, the James Bay Northern Quebec Agreement (1975) and the Northeastern Quebec Agreement (1978). Inuvialuit came into ${ }_{234}$ effect 1 year after the report was released.

${ }_{234}$ Key issues included: membership, accountability, control of lands and resources, extinguishment, revenues, as well as the current relationship between Aboriginal groups and the federal government.

$235 \quad$ Penner Report, supra note 232 at 8.
} 
a need for the federal government to shift power over to the communities in order that INAC could begin the process of phasing itself out, as once self-government was achieved, the need for the department would no longer exist. More importantly, at least for the purposes of this paper, the committee recommended that the use of extinguishment to deal with Aboriginal rights and title be ceased. ${ }^{236}$

In 1985, another task force was struck up to review the Comprehensive Land Claims Policy (CLCP), in the context of growing resentment by Aboriginal groups for the policy that had been in existence since 1973. The task force was mandated to review the entire CLCP, including its certainty provisions. The task force purported that a new policy to address the issue of certainty, most notably with regard to the extinguishment provision, had to be undertaken. The report Living Treaties, Lasting Agreements, Report of the Task Force to Review the Comprehensive Claims Policy, (aka the Coolican Report) stated in its findings that "Aboriginal people wanted land claims agreements to affirm their rights to land and resources while governments insisted those rights be 'extinguished", 237

During the review problems focussed on the CLCP, and more specifically, on the issue of blanket extinguishment, finality, political rights, decision making powers and responsibilities in relation to land and resource management boards, etc. The Coolican Report also noted that these problems stemmed from the fact that the policy restricted However, in the end, the report was highly criticized by both bureaucrats and Aboriginal
organizations for failing to make practical recommendations, and for the lack of political clout that would
see a financial commitment from the government and ultimately transfer control to Aboriginal
communities. The government eventually responded to the issue of Aboriginal self-government, after
attempts failed to have an Aboriginal inherent right to self-government recognized in the Constitution, by
introducing the Inherent Right Policy in 1995 , and subsequently began negotiating self-government and
sectoral self-government agreements. The 1995 Inherent Right Policy outlines the Government of
Canada's approach to implementing self-government agreements. Included in the policy is an itemized
list of what are considered the "range of matters" which the government is willing to negotiate. Canada,
Aboriginal Self-Government: The Government of Canada's Approach to Implementation of the Inherent
Right and the Negotiation of Aboriginal Self-Government (Ottawa: Minister of Public Works and
Government Service Canada, 1995). Sectoral self-government agreements focus on one or more rights
such as education, policing, etc. However, the issue of ceasing extinguishment was ignored by the Crown
until it was addressed by another committee two years later.
237 
claims negotiations to non-political matters and that Aboriginal rights related only to land. ${ }^{238}$ It further noted that:

To many Aboriginals, Aboriginal rights are intimately tied to culture and lifestyle and are integral to their self-identity. The blanket surrender and extinguishment of these rights suggest assimilation and cultural destruction. It is partly for these reasons that Aboriginal groups fought so vigorously for the entrenchment of their rights in the Canadian Constitution.

The report highlighted the need to find 'common ground' in the negotiation of land claim agreements that clearly set out the aims, objectives and principles of the parties within the agreements. ${ }^{240}$

To address many of the concerns raised with the negotiation and conclusion of final agreements, the report suggested three alternatives to extinguishment containing four basic characteristics: Aboriginal acceptability, encouragement of investment development, simplicity, and familiarity (e.g., is it compatible with the domestic legal system). ${ }^{241}$ This resulted in the proposed following alternative options:

- certainty was the recognition of a broad set of Aboriginal land-based rights and was fashioned after the historic treaties which adopted partial or limited surrender;

- a combination of a broader Aboriginal rights approach coupled with the idea that rights extend beyond mere land-based rights, thus allowing for the inclusion of cultural, social and political rights ${ }^{242}$; or

- set aside the issue of Aboriginal rights, dealing only with title, yet adopting more of a co-operative or co-management technique in which neither party is required to concede its position. ${ }^{243}$ CLCP did not acknowledge or address non-land related rights, certainty would still be achieved.

However, the task force was strongly opposed to any policy that required full surrender or extinguishment of Aboriginal rights, but a partial surrender could be used when necessary.
} 
The federal government responded to the report by making minimal changes to its policy, but they did eliminate the blanket extinguishment clause (1986):

In order to be consistent with the Canadian Constitution which now 'recognizes and affirms Aboriginal and treaty rights, a Liberal government will not require blanket extinguishment for claims based on Aboriginal title. ${ }^{244}$

This meant that rights would no longer be extinguished under a modern-day treaty; instead, rights and title would be surrendered and ceded to the Crown. ${ }^{245}$

In March of 1995, RCAP released an interim report titled Treaty Making in the Spirit of Co-Existence, which examined the effects that extinguishment policies have had on all aspects of Aboriginal rights. The commission noted that:

If culture can be described as the celebration and continuation of a distinct people's identity, heritage and inherent rights, extinguishment is most often associated with a policy of finality and termination. In the wake of extinguishment, Aboriginality in all its essential forms is left in a kind of permanently fragmented or amputated state. The Aboriginal peoples affected by extinguishment claims are often rendered even more vulnerable as a result. The survival of Aboriginal peoples as distinct, self-determining peoples becomes extremely difficult. Continuity with their past, their ancestors and their territories is severed. ${ }^{246}$

Based on the above noted assertion, the commission recommended that the certainty provisions be based on a co-existence model, where explicit Crown and Aboriginal rights would be recognized, with each party agreeing to respect and recognize the other. Blanket extinguishment provisions would be excluded, but partial extinguishment could be used as a last resort.

A year later, in 1996, the RCAP released a comprehensive report, totalling five (5) volumes, chronicling Aboriginal life in Canada since contact. Included in the documentation was the refined interim report on extinguishment, released a year earlier.

\footnotetext{
$244 \quad$ RCAP, supra note 55 at 5.

245 In 1990, the government also removed the limit on the number of claims that would be accepted each year, but maintained that the certainty clauses (e.g., cede, release, and surrender) brought the clarity and predictability that Canada needed.

${ }_{246}$ RCAP, supra note 55 at 3.
} 
The report echoed the interim findings on co-existence, mutual recognition, blanket extinguishments and called on the parties to seek alternative models to achieve certainty. ${ }^{247}$

In 1995, the Honourable A.C. Hamilton, who undertook a fact finding exercise at the request of the Minister of INAC, presented a report entitled: Canada and Aboriginal Peoples: A New Partnership. ${ }^{248}$ Through a series of public hearings, discussions, position papers and meetings with provincial parties, the fact finding mission focussed on identifying barriers in the negotiation of land claim agreements to achieving certainty as well as suggesting viable alternatives to surrender models.

\footnotetext{
247 RCAP put forth over 400 recommendations. The following are excerpts from the report with regard to certainty:

The Federal Government adopt a new approach in its comprehensive claims negotiations with Aboriginal peoples, that is, one based on the concepts of co-existence and mutual recognition.

The Federal Government not seek to obtain blanket extinguishment of Aboriginal land rights in exchange for rights or other benefits contained in comprehensive agreements. The Federal Government not require partial extinguishment of Aboriginal land rights as a precondition for negotiating comprehensive agreements.

Parties strive to identify, as exhaustively as possible, their respective rights by agreement.

Aboriginal rights not recognised by an agreement would not be extinguished, but their exercise would be subject to existing third-party interests and the terms of the agreement.

Aboriginal rights recognised by an agreement ought to be worded to permit their evolution in light of favourable legal developments. Aboriginal rights not recognised by the agreement also ought to be permitted to evolve in light of future legal developments.

That governments accept that Aboriginal rights recognised by the agreement are treaty rights. The clarity and certainty that this would provide Aboriginal parties ought to be the quid pro quo for the clarity and certainty that would accrue to governments by the fact that the terms of the agreement would take precedence in the event of conflict with Aboriginal rights not recognised by the agreement.

That a policy that recognises and affirms Aboriginal rights and emphasises co-existence, mutual recognition, and shared ownership and jurisdiction is to be preferred over current federal extinguishment policy. Federal provincial and territorial governments can achieve a sufficient degree of clarity and certainty without requiring Aboriginal nations to agree to extinguish existing Aboriginal rights.

Australian Indigenous Law Reporter, Canadian Royal Commission on Aboriginal Peoples: Interim Reports (1996) online: AustLII <http://www.austlii.edu.au/au/journals.OLD/AILR/1996/8.html> (date accessed: 7 February 2004).

In 1998, the federal government responded to the Royal Commission's report with Gathering Strength: Canada's Aboriginal Action Plan (Department of Indian and Northern Affairs Development, (1997) Gathering Strength: Canada's Aboriginal Action Plan, Minister of Indian Affairs and Northern Development, Ottawa.) Based on what RCAP called the four (4) touchstones, the federal government developed four (4) pillars: renewing the partnerships; strengthening Aboriginal governance; developing a new fiscal relationship; and supporting strong communities, peoples and economies. ${ }_{248}$ Hamilton's report was tabled a few months after the release of RCAP's interim report and a year before the release of its comprehensive report.
} 
To assist the committee, INAC and the Department of Justice (DOJ) presented a background paper Achieving Certainty in Comprehensive Land Claims Settlements ${ }^{249}$, outlining seven alternative models to achieve certainty. The following chart presents extracts from the alternative certainty provisions proposed by INAC and DOJ. ${ }^{250}$

\begin{tabular}{|c|l|}
\hline MODEL & \multicolumn{1}{|c|}{ PROPOSED ALTERNATIVE METHOD OF CERTAINTY'51 } \\
\hline $1 \& 2$ & Aboriginal people surrender their rights in exchange for new rights \\
\hline 3 & $\begin{array}{l}\text { Replace the words cede, release and surrender with "quitclaim, relinquish, } \\
\text { exchange or cession" of Aboriginal rights for defined rights or benefits. }\end{array}$ \\
\hline 4 & $\begin{array}{l}\text { The word surrender is used but is limited to the surrender of lands and resources } \\
\text { that are not defined in the negotiated agreement. }\end{array}$ \\
\hline 5 & $\begin{array}{l}\text { Based upon an agreement not to exercise Aboriginal rights with respect to the land } \\
\text { and resources, other than those set out in the treaty. }\end{array}$ \\
\hline 6 & $\begin{array}{l}\text { Suggests three ways to determine the rights of Aboriginal people in a treaty area. } \\
\text { 1. Exhaustively define the land and resource rights of the Aboriginal party under } \\
\text { section 35 of the Constitution Act, 1982, } \\
\text { 2. Define Aboriginal rights in section 35 of the Constitution Act, 1982, at the time } \\
\text { of the settlement, } \\
\text { 3. Treaty would exhaustively define the rights and obligations of the Aboriginal } \\
\text { party, the Crown and third parties. }\end{array}$ \\
\hline 7 & $\begin{array}{l}\text { Notion of "'rolling' surrender which includes the terms cede, release and } \\
\text { surrender. "The parties would agree that all of their rights and the rights of third } \\
\text { parties, with respect to lands and resources, are set out in the agreement, and that } \\
\text { such rights would only be exercised as set out in the agreement." }\end{array}$ \\
\hline
\end{tabular}

Hamilton was highly critical of INAC's and DOJ's proposed models and countered with the following statement:

A treaty should, as much as possible, set out or describe the rights of all parties to the treaty and the rights of others affected by it as well. It is important that each party know the extent of their own rights as well as the extent of the rights of others. ...Treaties should describe the general rights and obligations of all parties in both types of land to the greatest extent possible. ... The rights of third parties and the

\footnotetext{
$249 \quad$ Hamilton Report, supra note 5 at 84-87.

$250 \quad$ Ibid. at 84-87.

251 Hamilton Report, supra note 5 at 84-85. The proposal put forth by INAC and DOJ only reaffirmed Aboriginal concerns that INAC was only looking for a more politically correct term to replace extinguishment while skirting the real issue - a complete overhaul of the CLCP. AFN, supra note 182 at 1 and 2.
} 
public should also be described in sufficient detail to allow the Aboriginal party to know how its rights fit with the rights of others. ${ }^{252}$

According to Hamilton, in order to achieve certainty when settling land claim settlements, six factors are of particular relevance: 1) the preamble clause - which recognizes rights and the desire to achieve certainty; 2) mutual assurances - as a means of fostering equality and cooperation; 3) the rights and interests of parties in relation to lands; 4) dispute resolution; 5) judicial review; and 6) amendment process. ${ }^{253}$

Of all the reports, Hamilton presented the most liberal and progressive of the varying approaches; unlike the others, Hamilton would not accept as a viable solution any model that required the surrender of rights in any manner. Hamilton asserted that "certainty can be achieved without a surrender and without diminishing the interests of anyone whether they are directly involved in the process or likely to be affected by a treaty". ${ }^{254}$

However, Hamilton's model is not without its own set of problems. A more detailed analysis of the benefits and weaknesses associated with Hamilton's models will be examined in Chapter 6, where it will also be compared against an alternative model.

\section{B. Co-Existence and Mutual Assurances}

The significance of the Penner, Coolican, Hamilton and RCAP reports lies in the fact that they were all attempts at building models of co-existence. In co-existence models, if applied correctly, both parties have various aspects of rights recognized; despite the difference in cultural, political, and social application, rights could co-exist within one overarching social structure. Models of co-existence are not new in the realm of negotiating treaties with Aboriginal groups or in addressing Aboriginal rights and title in general, nor are they unique to Canada; the Australian courts addressed the very notion of co-existence in the

\footnotetext{
$252 \quad$ Ibid. at 102-105.

253 See annex 5 for an outline of Hamilton's model.

254 Hamilton Report, supra note 5 at $i$.
} 
$M a b o^{255}$ and $W i k^{256}$ cases by affirming that Aboriginal title was an interest in the land and was capable of co-existing with other interests in land. ${ }^{257}$

According to H. Stewart, the problem has been that over the years: "the range of coexistence models range from methodical ethnocide, military subjugation, out and out assimilation, ethnic isolation, treaties, disregard or lip service to ethnic autonomy, multicultural/ethnic pluralism and regional Aboriginal self-government and self-determination."258 Stewart's criticism is highlighted by the way the federal government addresses modern-day treaties. According to governmental policy "the primary purpose of the comprehensive claims settlements is to conclude agreements with Aboriginal groups that will resolve the debates and legal ambiguities associated with the common law concept of Aboriginal rights and title". ${ }^{259}$ While the rationale may seem reasonable, P. Rynard argues that by using the federal government's approach to negotiating treaties, “Aboriginal title is a 'burden' or obstacle to be overcome; [while] Aboriginal title as an opportunity for mutual accommodation and co-existence is lost" ${ }^{\prime 260}$, thus the negotiation process and the achievement of certainty is stagnated.

Throughout the reports, all parties agree that certainty is an essential component in the settlement of modern-day treaties. However, within the reports and in the current

\footnotetext{
255 In Mabo the court recognised native title is part of Australian land law. Native title continues in cases where Indigenous people have an on-going connection with their traditional lands as determined by their own laws and customs, and an act of the Crown has not extinguished these rights. As a direct result of this case the Native Title Settlement Act was enacted which established a land claim hearing and resolution process. Province of British Columbia, Social and Economic Impacts of Aboriginal Land Claim Settlements: A Case Study Analysis - Final Report (1995) online: gov, bc $<$ http://www.aaf.gov.bc.ca/aaf/pubs/arafr.htm> (last modified: 1995) at 2.

${ }_{256}$ In Wik, the High Court decided that the grant of a pastoral lease does not necessarily extinguish native title, ie that native title can co-exist with rights conferred to pastoralists under the terms of their leases. However, according to $W i k$, where there is conflict in the exercise of those rights, native title rights are subordinate to those of the pastoral lease holder. Wik Peoples v. Queensland (1996), 187 C.L.R. 1 257 M. Tehan, "Co-existence of Interest in Land: A Dominant Feature of the Common Law" (1997),

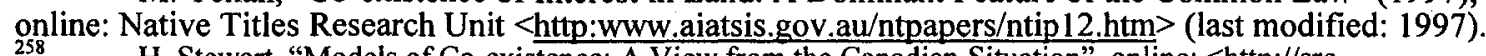
258 H. Stewart, "Models of Co-existence: A View from the Canadian Situation", online: <http://srch.slav.hokudai.ac.jp/sympo/97summer/henry.html $>$ (last modified: 1998) at 1 .

239 M. Asch and N. Zlotkin, supra note 199 at 213

260 P. Rynard, "Welcome In, But Check Your Rights at the Door": The James Bay and Nisga'a Agreements in Canada, online: wlu <http:/www.wlu.ca/ wwwpress/jls/cjps/issues/33.2/rynard.html $>$, (last modified: 10 August 2000) at 13.
} 
context, the parties have differing views in relation to Aboriginal title and rights, as well as divergence over the methods deployed to achieve certainty. Additionally, aside from the common attributes in the differing attitudes towards Aboriginal rights and title and how certainty, predictability and clarity could be best achieved, the reports also highlight a number of other areas that need to be addressed under a co-existence model. These include: third party and economic interests; diversity and flexibility; and cooperative relationships.

\section{Third Party Interests and Economic Investment}

In addressing the issue of certainty, all the above mentioned reports noted that 'third party interests' ${ }^{261}$ play an important role. While most agreements appear to be negotiated between the federal government and Aboriginal groups, securing provincial/territorial and third party participation is regarded as crucial in achieving certainty. ${ }^{262}$ This is attributed to the fact that attempts to achieve certainty of title have often been delayed due to other governmental departments, third party interests, complex definitions and jurisdictional issues.

As already noted, the transfer of ownership and rights to large areas of land and resources, and cash payments to Aboriginal communities are usually the major features of a claim settlement. Economic and social benefits to the claimants can include participation in resource management, including water, wildlife, subsurface and offshore assets, as well as resource and revenue sharing, as seen in the James Bay ${ }^{263}$, Nisga'a and

\footnotetext{
261 Third parties interests are not just limited to business and resource sectors, the general public's interests are also an important factor in relation to treaties and certainty. The AFN has stated: "It is the desire of First Nations to have their claims, rights and title recognized in a way which will not cause hardship or loss to third parties, especially families, small businesses or farmers". AFN, supra note 172 at 23 .

${ }_{262}$ The Comprehensive Claims Branch (CCB), the branch responsible for negotiating land claim agreements within INAC states: "...the primary goal [of CCB] is to negotiate modern treaties which will provide a clear, certain, and long-lasting definition of rights to land and resources for all Canadians: thus...ensuring that the interests of the general public and existing legal interests are respected under these agreements and, if affected, are dealt with fairly". Indian and Northern Affairs Canada, Comprehensive Claims Branch Introductory Web Page, online: INAC $<$ http: $/ /$ www.inac.gc.ca/ps $/ \mathrm{clm} / \mathrm{ccb}$ e.html $>$ (last modified: 31 December 2000).

${ }_{263}$ These provisions were added subsequent to the agreement being signed.
} 
the Tlicho Agreements (See Chapter 5). Most of the lands and resources which are subject to the comprehensive claims negotiations are under provincial jurisdiction. It is for this reason, as well as the fact that land claim settlements benefit the provinces and territories, that the federal government must ensure that the provincial and territorial governments actively participate in negotiations and contribute to the costs of the settlement. ${ }^{264}$

In 1984 in Guerin $v R^{265}$ the SCC stated that the federal government was legally bound by a fiduciary obligation in relation to Aboriginal interests and affairs, above those of the general public, yet third party interests still play a role in defining certainty. For the business community and/or resource sector of an area under claim, the uncertainty associated with an unsettled land claim can be far more costly than that of the settled claim. For example, in 1990, it was estimated that the cost to BC of not settling land claims was $\$ 1$ billion in lost investment and approximately 1,500 lost jobs a year in mining and forestry sectors. ${ }^{266}$

In the majority of reports, noted in section $\mathrm{A}$ of this chapter, different third parties from across the country expressed concern for their own rights if Aboriginal rights were recognized and protected. ${ }^{267}$ Concerns for certainty in relation to a settled agreement or disputed land base involved the access to current and future resources. Certainty for these groups focussed around their desire to conduct business practices in a stable and predictable environment. ${ }^{268}$ Yet with land claim negotiations taking anywhere from five to twenty years to settle, many investors simply do not want to make a commitment. Thus, business owners and/or resource sectors viewed certainty as a prerequisite to

\footnotetext{
264 Indian and Northern Affairs Canada, Federal Policy for the Settlement of Native Claims (1993), Minister of Indian Affairs and Northern Development, Ottawa, Canada.

$265 \quad$ Guerin v R [1984] 2 S.C.R. 207

266 Indian and Northern Affairs Canada, Resolving Aboriginal Claims: A Practical Guide to Canadian Experiences, (Ottawa: Minister of Indian Affairs and Northern Development, 2003) at 9. $267 \quad$ Hamilton Report, supra note 5 at 56.

268 lbid.
} 
achieving economic development.

A fundamental departure between the conceptual model outlined in Chapter 6 and Hamilton's recommendation centres on the issue of defining third party and governmental rights. In relation to third party interests, Hamilton expressed:

Certainly Aboriginal people want the treaties to regularize the arrangements and their rights and their use, to the extent of their use of traditional lands. Third parties have exactly the same needs. They have to get their position regularized. ${ }^{269}$

I assert that this recommendation is problematic for two reasons. While I do believe that provincial and third party interests should be given consideration, and when and where necessary accommodated, it begs the question as to whether their interests are best served by being clearly and concisely defined in a treaty that is negotiated between Aboriginal groups and the federal/provincial Crown. Treaty rights are protected under s.35 of the Constitution Act and the question must be posed: to what extent should the rights of others be protected? Part of the problem is in the difficulty of defining third party rights. Would these rights be considered treaty rights and would they be constitutionally protected? Is the intent of the treaty to define everyone's interests, or should the treaty process acknowledge third party rights and then set them aside to be dealt with after the treaty is negotiated?

I would disagree with Hamilton's assertion that third parties have the exact same needs, to have their position regularized as Aboriginal peoples. ${ }^{270}$ Hamilton is attempting to achieve "practical reconciliation"271 by advocating a sense of equality for all to have their interests represented in the treaty. Practical reconciliation ignores the fact that equal treatment does not equate with equality and that differential treatment does not always

\footnotetext{
$269 \quad$ House of Commons, Standing Committee on Aboriginal Affairs and Northern Development 924 October 1995) 1225 (A.C. Hamilton).

270 It is recognized that in certain situations third party rights may have to be set out in the treaty. However, it should be the exception and not the norm.

$271 \quad$ J. Borrows, "Practical Reconciliation, Practical Re-Colonisation?" (2004) 2 Land, Rights,

Laws: Issues of Native Title 1.
} 
equate with inequality. ${ }^{272}$ Practical reconciliation purports to achieve 1) improved living conditions; 2) acknowledgement of inter-related histories; and 3) mutual acceptance. At the same time, it ignores the effects of colonialization and suggests that Aboriginal people have the same access to opportunities enjoyed by other Canadians. ${ }^{273}$

My second point of departure from Hamilton focuses on exhaustively setting out rights. Despite the fact that Hamilton was highly critical of the complexity of the agreement, he further recommended that the treaty should exhaustively set out the rights of all parties, including those of the federal/provincial governments and third parties. ${ }^{274}$ To this he noted:

The detail of how that is reflected [exhaustive description of rights] in the treaty is the task of the drafters of the treaty. The clearer a treaty can be in reciting general rights to the land and resources the greater the certainty will be. ${ }^{275}$

Attempting to exhaustively set out rights in the agreements will only add to the criticisms of a negotiation process that is currently bogged down and costly. ${ }^{276}$ The treaty should be the framework to building co-operative relationships and ensuring that obligations arising from the treaty will be fulfilled. The danger in exhaustively setting out rights is that it suggests that rights and/or social situations cannot evolve over time and that all groups are seeking the same type of certainty; thus falling prey once again to the practical reconciliation model because it assumes that equal treatment equates to 
equality. Mark Stevenson, a former chief negotiator for the Province of British Columbia noted in a speech to the Law Commission of Canada in 2001:

...the type of certainty that third parties require to ensure their investments in economic development in the natural resource sector are secure is dependent upon a whole series of factors. These factors include, for example: the rise and fall of pulp and paper prices, the fluctuations of the dollar, the intricacies of the softwood lumber agreement/negotiations; the free trade agreement; emerging environmental issues; the dwindling fish stocks; the Asian economy; the price of oil; confidence in the government in power; labour issues, etc. ${ }^{277}$

For example, when a company looks at the viability of an investment and the inherent risk involved, they must make certain assumptions for variable factors such as market prices, economic growth, political environment, etc. Due to the fact that many of these factors are uncontrollable, the risk can be minimized be solidifying factors that they can control, such as certainty over lands and resources.

However, the certainty that businesses desires can still be achieved without having their interests detailed in a treaty. To this end, in 1995, the ARA Consulting Group Inc. examined the social and economic impacts of Aboriginal land claim settlements. The findings in relation to land and resource use and management showed that:

1. The climate for investment has generally improved as a result of settlement, in part due to increased certainty surrounding the conditions that govern investments.

2 . In general, the level of land and resource use has not decreased as a result of land claim settlements.

3. A variety of land resource management structures have been formed as a result of settlements. ${ }^{278}$

In examining business development and operations, the findings noted:

1. The reaction of the non-Aboriginal community to settlement has generally been positive.

2. In each of the cases Aboriginal mechanisms exist or are planned to carry

Stevenson, supra note 13 at 8. [Emphasis Added].

$278 \quad$ Ministry of Aboriginal Affairs, Province of British Columbia, Social and Economic Impacts of Aboriginal Land Claim Settlements: A Case Study Analysis Final Report (December 1995) online: AAF $<$ http://www.aaf.gov.bc.ca/aaf/pubs/arafr.htm> (date accessed: 19 February 2001) at 10. 
out business investment. Aboriginal groups have taken a variety of approaches to business investments, including investment in a number of non-traditional businesses.

3. Aboriginal groups have generally been open to joint venture arrangements with the non-Aboriginal business community. ${ }^{279}$

However, some of the concerns regarding the length of time it takes to negotiate a treaty and provide a sound economic environment which investors are seeking have been alleviated with the introduction of Interim Measures Agreements (IMAs) ${ }^{280}$ and Treaty Related Measures (TRMs) ${ }^{281}$. Canada's interest in securing IMAs and TRMs is to provide 'interim certainty' in the absence of a final agreement, especially in those areas for vast resource development potential. Interim certainty not only allows for the access to resource rich lands, but also enables Aboriginal groups and corporations to form entrepreneurial relationships at an earlier stage in the negotiation process.

Based on my opinion that it would be extremely difficult, time consuming and impractical to define everyone's interest in an agreement, my reconciliation model of certainty will exclude third parties from having rights set out in the treaty, exhaustively or otherwise. However, it should be noted that the reconciliation model of certainty will take into consideration the need to accommodate their interests and their desire to negotiate economic development opportunities with Aboriginal communities.

\section{Diversity and Flexibility}

The findings within the reports agreed that any policy designed to address

\footnotetext{
Ibid. at 14.

280 The objective of the IMA is to create an environment conducive to long term negotiations on land, resource and self-government issues by affording a measure of protection to Aboriginal interests during the period that an agreement is being negotiated while balancing public, third party and crown interests. IMAs can provide for: participation in resource management regimes; land withdrawals; a regional land use planning process that will facilitate oil and gas exploration and for co-operative management of parks. ${ }_{281}$ TRMs, which are only negotiated in $\mathrm{BC}$, were created to help negotiators conclude treaty agreements more quickly. TRMs take the form of time-limited agreements designed to: (i) accelerate negotiations with tools such as treaty-related land, resource and economic development studies; (ii) preserve negotiating options by protecting Crown lands, and by acquiring available private land for treaty settlement; (iii) prepare First Nations to implement anticipated treaty settlement by enhancing the role of First Nations on anticipated treaty settlement land and developmental measures supporting governance; or (iv) take advantage of limited time sensitive economic and cultural opportunities by providing First Nations with pretreaty access to small portions of anticipated treaty benefits within financial constraints.
} 
Aboriginal rights and/or title must be flexible enough to accommodate differences amongst the groups, not only in the various stages of negotiations, but in the final agreement as well. The Coolican task force noted that the policy had to allow for evolution, adjusting itself from time to time in the way of renewed rights, since the finality that the government sought was unachievable given the complexity of the agreements. One of the key challenges for INAC has been to develop, in partnership with Aboriginal groups, processes/mechanisms which support the overall mission of the department, yet which are flexible enough to take into consideration the varying degrees of social, economic and political diversity of Aboriginal communities. Without such processes, litigation and confrontation will continue to grow or just be 'managed', resulting in high resource costs and delayed attention to improving quality of life.

In September of 1998, the Office of the Auditor General (OAG) of Canada released the Auditor General Report on Comprehensive Land Claims ${ }^{282}$, reiterating many of the concerns raised in earlier reports. Among the recommendations, the OAG noted that "to help enhance the achievement of certainty, Indian and Northern Affairs Canada should further address differing expectations of the parties relating to rights, capacity and implementation needs". ${ }^{283}$ In its 2001 and 2006 follow up audits, the OAG once again noted that the achievement of certainty in land claim negotiations continues to be a significant challenge, as fundamental differences in the parties' goals for land claims continue to impact on the process. Yet despite the OAG's and the AFN's criticisms of the negotiation process, the then Minister of INAC, Robert Nault responded that:

...the existing policy is sufficiently flexible to accommodate the concerns of First Nations. ...the best way to resolve outstanding issues of Aboriginal rights and title and to address capacity and implementation issues is at individual negotiating

\footnotetext{
282 Office of the Auditor General, Report of the Auditor General of Canada to the House of Commons, (1998) online: OAG $<$ http://www.oag-bvg.gc.ca/domino/reports.nsf/html/0112ce.html > (last modified: December 1998).

${ }_{283}$ Ibid at 14.46 [Emphasis added].
} 
tables where the unique circumstances of each claim are taken into account. ${ }^{284}$ Under a co-existence model, parties could negotiate co-management agreements to ensure Aboriginal parties are able to exercise their rights and that these rights are not infringed upon by others. For example, the Nacho Nyak Dun First Nation Agreement, signed in 1993, advocates for a coordinated approach to lands not within the settlement area. ${ }^{285}$ This was done by:

1. Allowing the First Nation, Yukon Government and/or municipal government to set up a joint planning structure to develop land use plans; and

2. Requiring consultations between the First Nation and local government where a proposed land use of Settlement or non-settlement land may have a significant impact on the use of the adjacent land with the purpose of resolving an actual or potential incompatibility. ${ }^{286}$

\section{Co-operative Relationships}

Another commonality of the reports notes the desire of all the parties to achieve some type of certainty, in order that rights, title and responsibilities are clarified. The reports maintained that the adversarial system was not the best avenue to pursue in order to seek clarity and definitions on Aboriginal rights, title and treaty relationships.

In deciding Delgamuukw, the SCC clearly indicated that negotiations are the best way to reconcile the interests of Aboriginal and non-Aboriginal Canadians. Negotiations appear to be the best way to promote partnerships and enhance future relations since it is through the negotiation process that Aboriginal groups, the Crown, and other parties can proceed within the framework of 'interest' based negotiations. In a recent statement to the Edmonton Journal, Justice Michel Bastarache reaffirmed that the Supreme Court was not the best forum to resolve Aboriginal land claim issues. Justice Bastarache went on to

\footnotetext{
$284 \quad$ Office of the Auditor General, Report of the Auditor General of Canada to the House of Commons, (2001) online: OAG <http://www.oag-bvg.gc.ca/domino/reports.nsf/html/0112ce.html > (last modified: December 2001) at 12.133.

285 The Agreement was signed by the Nacho Nyak Dun First Nation, the Government of Canada and the Yukon Government.

${ }_{286}$ Union of British Columbia Municipalities, "Land Use Coordination, Servicing and Dispute Resolution: Towards Certainty for Local Government Through Treaty Negotiations" (2000) online: ubcm

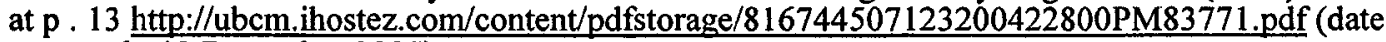
accessed: 13 December 2005).
} 
say that since Aboriginal rights are 'ill-defined', the negotiation process remains the best option to resolve outstanding issues and provide certainty in relation to rights and title. ${ }^{287}$

A co-existence model allows for interest based negotiations that focus on a group's core needs, concerns and intentions, allowing for uncodified amenable laws that can be applied in a variety of circumstances. Given the long adversarial history of mistrust and animosity between the Crown and Aboriginal groups, negotiations can be viewed as an attempt to break down barriers by advocating a 'win-win' situation for all parties based on mutual respect. Successful negotiations can be a highly interactive process that allows the parties to move away from the "predetermined linear scales" 288 of justice and seek new solutions. Furthermore, as Asch and Zlotkin note, "the central focus of negotiating treaties is to reach an agreement about how these rights, already recognized in the Constitution, are to be implemented by Canada". ${ }^{289}$

\section{Recognition}

As noted extensively throughout this paper, the notion of ownership and jurisdiction over title and rights has been a major stumbling block in the negotiation of historic and modern-day treaties. While section 35 of the Constitution Act, 1982 recognizes and affirms existing Aboriginal rights in Canada, it does not define the nature, scope or extent of those rights. The SCC has also stated that Aboriginal rights are specific to each particular Aboriginal group's traditional use of a site or area.

The Government of Canada currently accepts the notion that Aboriginal rights have been recognized by the courts and affirmed by the Constitution Act, 1982. However, it also argues that "given that rights are common law...their extent and nature

\footnotetext{
287 C. Schmitz, "Land claims not court"s turf", The Edmonton Journal (15 January 2001) A3.

288 A. McCallum, "Dispute Resolution Mechanisms in the Resolution of Comprehensive Aboriginal Claims: Power Imbalance Between Aboriginal Claimants and Governments", (1995) online: E Law $<$ http://www.murdoch.edu.au/elaw/indices/title/mccallum abstract.html $>$ (last modified: 29 November $2001)$.

289 M. Asch and N. Zlotkin, supra note 199 at 216.
} 
have been subject to considerable debate" ${ }^{290}$ This debate has lead to federal policy that attempts to achieve certainty through cede, release, surrender and/or modification, thus resulting in difficulties in the negotiation process. ${ }^{291}$

The Crown maintains that it is legal possessor of lands and resources contained within its borders. At the onset, in order for Aboriginal groups to begin the negotiation process, they must meet a set criteria that was established by the federal government without consulting Aboriginal groups. ${ }^{292}$ Conversely, Aboriginal groups note that while Canadian law gives the Crown underlying title to all of its lands, "the Crown's claim to title does not translate to actual title until Aboriginal title has been dealt with". ${ }^{293}$ To this, the BC First Nations Summit further notes that: Canada is not negotiating with First Nations to extinguish Crown title. Neither will First Nations negotiate with Canada to extinguish Aboriginal title. ${ }^{294}$

The problem of recognition and jurisdiction is further compounded by the ongoing "federal-provincial wrangling" over who has responsibility for lands, resources, and who should be held responsible in the treaty making process. Resolving these issues is also complicated by differences in provincial and territorial laws governing areas such as hunting and fishing, and differences in approaches to resolving disputes. ${ }^{295}$ Since the majority of the subject matter associated with land claims and Aboriginal self-

\footnotetext{
$290 \quad$ Hamilton Report, supra note 5 at 2.

291 Asch and Zlotkin note that: "...a central purpose of negotiations is to reach an agreement about how these rights, already recognized in the Constitution, are to be implemented by Canada". M. Asch and $\mathrm{N}_{292}$ Zlotkin, supra note 199 at 216.

293 See Appendix 4: Acceptance of Claims.

293 AFN, supra note 176 at 4. [Emphasis Added].

294 First Nations Summit, "First Nations Summit Statement to The Honourable Jane Stewart, Minister of Indian Affairs, Government of Canada and the Honourable John Cashore, Minister of Aboriginal Affairs, Province of British Columbia on the Supreme Court of Canada Decision in Delgamuukw" (31 January 1998) at 2.

295 For example, up until 1991, BC continued to resist participation in treaty negotiations by claiming that Aboriginal rights and title had been extinguished after 1871 when the province of $B C$ entered Canadian confederation, and even if title were not extinguished, responsibility for resolving claims lay with the federal government.
} 
government are under provincial jurisdiction, this resistance has prevented many land claim negotiations from proceeding.

For Aboriginal groups, the current certainty clauses which require them to cede, release, surrender or modify rights and title are not viewed as the government attempting to achieve clarification, predictability or co-existence. Instead, these are viewed "as a contemporary means of furthering what was a long-standing overt objective of federal policy: the assimilation of Aboriginal people into the Canadian mainstream". ${ }^{296}$

Both RCAP and Hamilton note that a recognition of rights and title would not affect the government's desire to achieve certainty. To this, Hamilton noted many examples of where the extinguishment of rights and title had not actually resulted in the certainty the government sought. ${ }^{297}$

A recognition of rights and title shifts the focus from giving lands and rights as defined by the treaties in exchange for surrender to recognizing that Aboriginal people have "constitutionally protected interests in land". 298 M. Stevens notes that under a recognition model "treaty making is an attempt to achieve certainty by redefining the relationship of governments and Aboriginal peoples and so clarifying the different parties' rights with respect to the ownership and use of land". 299

While the recognition model has some appealing qualities, such as a recognition of rights and title versus surrender, Stevens does not elaborate how redefining the relationship and clarifying the parties' rights in the treaty making process is different than what the government maintains they are attempting to achieve now. Thus, it is hard to determine if a recognition model would achieve different results than what is being negotiated today.

\footnotetext{
296 M. Asch and N. Zoltkin, supra note 199 at 218.

Hamilton, supra note 5 at 22-26.

Stevenson, supra note 13 at 125 .

Ibid. at 125 .
} 


\section{Summary}

Since the publication of the reports, in which millions of dollars have been spent on their production, only segments of the recommendations have been implemented. While all the parties agree that certainty is important and even necessary, challenges lie in reconciling divergent views on the meaning and intent of achieving certainty in a contemporary context. Despite the ambiguity, these reports, and the subsequent responses to them by governments and Aboriginal groups, were instrumental in highlighting not only the differences but also the common ground (i.e., need for economic interest, diversity and flexibility, co-operative relationship and the needs/interests of third parties) of the parties to the negotiation process and in attempting to achieve certainty.

All the reports suggest that an alternative to full cede, release and surrender as a model of certainty can be achieved. However, in order for this to occur, both the Crown and Aboriginal groups need to build upon the common themes/ground and work towards developing viable solutions in those areas that are preventing the achievement of certainty.

The reports also highlight the need for techniques for achieving certainty based on models of co-existence and mutual assurances. Co-existence allows for varying degrees of rights and interests to exist despite differences in the application of these rights and interests; while mutual assurances allow parties to exercise some rights and agree to refrain from others, all within one overarching social structure.

As these reports have evolved, so too has the role/definition of certainty. This evolution becomes evident when taking a closer look at three modern-day treaties, namely the JBNQ, Nisga'a and Tlicho. It will be shown as Aboriginal rights and title were further defined by the courts and policies, the differences in terminology in the achievement of certainty became evident. 


\section{CHAPTER 5}

\section{THE EVOLUTION OF CERTAINTY}

To date, three methods to achieve certainty have been deployed in the settlement of 21 modern-day treaties. ${ }^{300}$ This chapter highlights the evolution of certainty from extinguishment to modification to non-assertion through three separate case studies. The first, the James Bay and Northern Quebec Agreement ${ }^{301}$ (1975), is the first modern-day treaty signed in Canada. The second, the Nisga'a Final Agreement ${ }^{302}$ (2000), the first modern-day treaty to be signed in the Province of British Columbia, will examine the modification model of certainty. The last, the Tlicho Agreement ${ }^{303}$ (2003), the first modern-day treaty signed in the Northwest Territories, will explore the use of the nonassertion model of certainty deployed in this agreement. The importance of these three cases moves beyond the mere evolution of the certainty provisions and examines the social and legal impacts on the communities during the negotiation process and implementation of the treaty, where applicable.

\section{A. CASE STUDY 1}

\section{The James Bay and Northern Québec Agreement}

"The needs and interests of the native peoples are closely tied to their lands; their lands are at the very centre of their existence." John Ciaccia ${ }^{304}$

On November 11, 1975, the Canadian Government, the Province of Québec, the Grand Council of the Crees, the Northern Québec Inuit Association, Hydro-Québec, the James Bay Development Corporation, and the James Bay Energy Corporation signed the

\footnotetext{
$300 \quad$ See Appendix 2 for names of the Final Agreements and the breakdown of certainty clauses within these agreements.

301 James Bay and Northern Québec Native Claims Settlement Act, S.C., 1976-77, c.32

302 Nisga'a Final Agreement Act, S.C., 2000, c.7

303 The Tlicho Agreement was signed in 2003. At the time this thesis was written, the Tlicho Agreement had not yet been enacted by Parliament.

John Ciaccia was a member of the National Assembly for Mount Royal and Special Representative of Premier Robert Bourassa. He wrote the philosophy of the Agreement found at the beginning of the $J B N Q A$. Ibid. at XIII.
} 
James Bay and Northern Québec Agreement (JBNQA). Deemed to be Canada's first modern day treaty, it was a pivotal event in Canada's land claims history.

\section{A. Background}

In the spring of 1971 , the Cree people of the James Bay Territory prepared for what was considered a very important season, for they were a people who sustained their subsistence as a hunting, gathering and trapping society from lands and traditional ecosystem knowledge passed down from generation to generation. ${ }^{305}$

On April 30, 1971, then Premier Robert Bourassa announced plans to construct the James Bay hydro-electric dam, on Cree and Inuit ancestral lands. The scope of the James Bay hydro-electric project included constructing four hydro-electric dams that would flood a vast area (over 8,722 square kilometres) of Cree and Inuit land. The news of the Québec government's plans outraged the Inuit and Cree who had never surrendered their lands or participated in any treaty signing processes.

In a fight to save their lands, the Cree and Inuit in the affected region organized themselves and constructed the Grand Council of the Crees ${ }^{306}$ and the Northern Québec Inuit Association ${ }^{307}$ to take on the Québec government and the James Bay Energy Corporation. In the summer of 1971 , the two Aboriginal organizations met to discuss the appropriate action to prevent the destruction of their rights and lands. ${ }^{308}$ Almost an entire year passed, and while talks continued with the federal government, the Québec

\footnotetext{
B. Diamond, Highlights of the Negotiations Leading to The James Bay and Northern Québec Agreement, [unpublished, archived at the Library of Indian and Northern Affairs]. The territory had a population of approximately 5,638 people.

The Council originated under the name Indians of Québec Association and in 1974 officially formed the Grand Council of the Cree, but for the purpose of this paper, I will use the wording throughout this section.

307 It was created by the federal government in order that the Inuit would have a representative organization to negotiate the land claim agreement. Upon passing a resolution, the Grand Council of the Cree and the Northern Québec Inuit Association requested that Jean Chrétien, then Minister of INAC, intervene as a trustee to protect the rights and land of the Aboriginal communities affected by Québec's decision.
} 
government refused to acknowledge any Aboriginal title or rights by continuing to proceed with construction of the dam.

Feeling frustrated, the Grand Council of the Cree and the Northern Québec Inuit Association initiated legal proceedings against the government of Québec and HydroQuébec, seeking an injunction to stop construction and to have the Provincial James Bay Region Development Act declared unconstitutional.

\section{B. The Legal Battles and Negotiation Process}

At the onset of the proceedings, the Québec government argued that the case should be dismissed on the basis that the Cree and Inuit had no rights to the land. Justice Malouf of the Québec Superior Court dismissed the provincial government's argument, and found that the Cree and Inuit did indeed have apparent rights to the land. This decision led the way for a hearing to begin on the interlocutory injunction ${ }^{309}$.

On November 15, 1973, Justice Malouf ordered the Quebec government "to immediately cease, desist and refrain from carrying out works, operations, [as well as] ...from interfering in any way with the rights of the Cree and Inuit..."310 Justice Malouf affirmed the rights of the Cree and Inuit to enjoy the lands and carry out their traditional way of life. However, it was to be a short lived victory for the Grand Council of the Cree and the Northern Québec Inuit Association; one week later (November 22, 1973), the Québec Court of Appeal suspended the effects of the injunction.

\section{Certainty Provisions of the $J B N Q A$}

In November of 1973, negotiations commenced with the Grand Council of the Cree, the Northern Québec Inuit Association, the Canadian government, the province of

\footnotetext{
$309 \quad$ An interlocutory injunction refers to having the parties suspend or temporarily stop their activities. The interlocutory injunction to cease construction of the James Bay project turned into a long and lengthy hearing, lasting 71 days, with Justice Malouf taking five months to deliberate.

$310 \quad$ B. Diamond, Highlights of the Negotiations Leading to The James Bay and Northern Québec Agreement, [unpublished, archived at the Library of Indian and Northern Affairs].
} 
Québec, Hydro-Québec, the James Bay Development Corporation, and the James Bay Energy Corporation. Under the direction of the Minister of INAC, negotiators were instructed to provide the Cree and Inuit with the moneys to partake in the negotiations and to hire lawyers. Following two years of long and intensive negotiations, the parties signed a twenty two page Agreement- in- Principle ${ }^{311}$ (AIP) that by today's standards of length and detail would seem inconceivable. ${ }^{312}$

Canada's first modern-day treaty was signed on November 11, 1975, detailing the area and rights which were to be granted to the Cree and Inuit communities. ${ }^{313}$ Under the agreement, the James Bay Cree and the Inuit received land, rights and a cash

settlement. $^{314}$

However, the settlement came at a cost. Under the surrender provisions in section 2.1 , both the Cree and Inuit agreed to "hereby cede, release, surrender, and convey all their Native claims, rights, titles and interest... to land in the Territory and in Québec.." ${ }^{9315}$ Through the notion of blanket extinguishment, all rights were extinguished for those set out in the agreement and the Constitution. ${ }^{316}$

Within the scope of the agreement, lands were categorized into three sections. Category I lands provided for exclusive use by the Cree and Inuit with a self-

\footnotetext{
$311 \quad$ This is the stage during which the parties negotiate the issues set out in the Framework Agreement.

${ }_{312}$ Reaching an Agreement-in-Principle (AIP) often takes longer than any other stage in the negotiation process. The AIP should contain all the major elements of the eventual Final Agreement. The Labrador Inuit Association (LIA) AIP is 342 pages without appendices. When the Final Agreement is eventually signed it will be roughly the same number of pages.

${ }_{313}$ This agreement, which came into effect in 1979, put an end to the legal proceedings which hovered over the negotiation process.

314 Noteworthy, under the various provisions set out in the agreement, the $J B N Q A$ effectively supersedes the Indian Act. The settlement amounted to $\$ 135$ million for the Cree and $\$ 90$ million for the ${ }_{315}$ Inuit.

315 JBNQA, supra note 301 at 7. For their part, Canada and Québec agreed under s 2.1 to accept the surrender of land. Under s.2.6 of the $J B N Q A$, the federal government, upon granting their approval "... extinguish[ed] all native claims, rights, title, and interests of all Indians and all Inuit and to the Territory..." 316 It is interesting to note that the wording in this agreement is very similar to the explicit surrender of Indian title found in Treaty 7 which states "the said Indians... do hereby cede, release, surrender and yield up to Government of Canada..." For more examples see, T. Flanagan, supra note 220. [Emphasis added].
} 
administration provision. ${ }^{317}$ The idea behind Category I lands was to allow the Cree and Inuit communities to preserve their economic livelihood and traditional customs on the land, yet still allow the rest of society access to the lands, upon approval from the Cree and Inuit. With regards to mineral and sub-surface rights, the province of Québec retained the legal rights to the resources, with the exception of mining and mineral activities currently under third party control. However, any activity that impedes or interferes with the Cree and/or Inuit's traditional livelihood must make compensation to the group affected. Notoriously, Category I lands were not designed to be reserve lands. Therefore the Cree and Inuit people living on Category I designated land must pay taxes. ${ }^{318}$

Category II lands are identified as those lands to which the Cree and Inuit people have exclusive hunting, fishing and trapping rights, yet do not have a right to occupancy. ${ }^{319}$ Under section 5.2.6 and 7.2.6, the general public cannot hunt, fish or trap on any lands within the boundaries of Category II without the consent of the Cree and Inuit. However, while the Cree and Inuit have an exclusive right to hunt, fish, and trap, the Québec government can at any time develop all or portions of the land for public or private use as long as they replace the land with an area that can sustain their traditional lifestyle.

The last category, Category III, is designated as lands for public use and falls within the appropriate provincial provisions.

With the federal and provincial governments now having ascertained certainty with regards to lands, the agreement set out the rights and benefits that the Cree and Inuit

317 This provision allowed for the Cree and Inuit to administer their communities as a municipality, therefore they could build schools, roads, hospitals, etc.

${ }_{318} \quad$ Although not considered reserves, the allocation of property is similar to that of the reserve system that currently exists in Canada. Also noteworthy is the fact that the province of Québec owns the lands and can expropriate any section of land as long as it is replaced by a section of land equal to the amount expropriated.

${ }_{319}$ Although Category II lands are owned by the province of Quebec, the Cree and Inuit have hunting and fishing rights and all parties to the agreement co-manage the tourism, forestry and mining activities. $J B N Q A$, supra note 301 at s. 7.2 .1 
would receive as compensation. In addition to receiving a financial component set out above, the Cree and Inuit communities also received full harvesting rights to over 150,000 square kilometres of forest, participation in an environmental and social protection regime, and an income security program for hunters and trappers.

\section{Summary}

The year 2000 marked the $25^{\text {th }}$ Anniversary of the $J B N Q A$, which now consists of the original signed document along with 10 complementaries. Amazingly, three decades after, the $J B N Q A$ has not been fully implemented. Since its creation, it has been hailed as both a victory as well as being highly criticized for its cede, release and surrender provisions, the failure of the treaty to be fully implemented, as well as for lack of consultation with other Aboriginal groups situated in the area. ${ }^{320}$ Matthew Coon Come, the former Cree Grand Chief noted 20 years after the signing that:

Extinguishment has injected a fundamental instability into the relationship between the Crees and the other signatories of the James Bay and Northern Quebec Agreement. For Aboriginal peoples, extinguishment is brutal conquest attempted with a fountain pen. It is a fundamental wrong, entrenched in provisions and laws that are fundamentally wrong.... Extinguishment is simply terra nullius [empty land -- an old colonial rationalization for expansion] applied after the fact... . Many of our collective and individual rights are to a large degree linked to our lands and resources. Extinguishment attempts to sever our relationship with our lands, undermining our identity and status. It attempts to deny us beneficial enjoyment of our resources, while making others wealthy and us dependent upon them for our basic needs. It puts the power to make decisions about our lands and waters, and thus about us, exclusively in the hands of others. Its imposition is thus a profound denial of our fundamental rights. ${ }^{321}$

Despite the criticisms, the $J B N Q A$ has provided a template for future agreements to build upon, as well as providing the necessary tools to ensure Cree and Inuit cultural identity has been maintained and that their traditional way of life will continue for future generations. Born out of a need for certainty, on the part of the Québec government and

\footnotetext{
$320 \quad$ Many groups that did not partake in the negotiation process had their rights and title extinguished by the signing of the $J B N Q A$. The Crown is currently negotiating modern-day treaties with those groups who were not signatories to the $J B N Q A$.

$321 \quad$ Rynard, supra note 260 at 12 .
} 
Hydro Québec, the $J B N Q A$ has provided certainty in the way of economic opportunities

for all the signatories. ${ }^{322}$

This economic development has resulted in massive housing programs, construction of airports, schools, and hospitals, the purchase and growth of Air Inuit and Air Creebec, and the overseeing of a \$122-Million portfolio. The Makivik Corporation also created and constructed the new community of Umiujag through the implementation of subsection 6.4 .

The $J B N Q A$ was an important document in establishing the model of certainty (e.g. cede, release, surrender and in some cases extinguishment) to be achieved in land claim settlements well into the 1990s. And despite the criticism of the extinguishment model of certainty, it was the method adopted in 12 of the 19 settled land claim agreements since the signing of the $J B N Q A$ (see appendix 5).

\section{B. CASE STUDY 2}

\section{The Nisga'a Final Agreement}

"This is a white man's world. It's not our world anymore. But it's still our landour culture is still there. If we are going to survive we have to send our children to school, whether we like it or not. I have said that our land guarantees our education in the white man's world forever. The white man cannot pay for our land-it is priceless. It guarantees our medical needs and taxation, our contribution to the country. It guarantees everything. That is why we say Nisga'a land is not for sale. We cannot sell it. Because without the land, what is going to be our survival?"'323

Almost 112 years after the initial plea to the Government of Canada to negotiate a treaty which would see the recognition of title and rights to self-govern, in 2000 the

\footnotetext{
322 In 1978, the Northern Québec Inuit Association was replaced by the Makivik Corporation, with a mandate to oversee the implementation of the $J B N Q A$, and the management and investing of the compensation funds. According to the third Vice President, Mark T, Gordon, "...despite flaws, the agreement provided the Inuit with the tools needed to develop the region. The Agreement itself is seen as a tool." S. Hendrie, The James Bay Agreement: 20 Years of Development, online: makivik $<$ http://www.makivik.org/MakivikNews/MN20thAnn/English/eMN20-Overview.html> (last modified: 29 August 2000). 10 .
} 
Nisga'a Nation, Province of British Columbia and the Canadian government signed the Nisga'a Final Agreement (NFA). This agreement was the first modern-day treaty signed in the province, as well as the first treaty to be signed using a different model from extinguishment and/or surrender to achieve certainty since the $J B N Q A$ was signed in 1975.

\section{A. Background}

From as far back as 1887 , the Nisga'a chiefs sought the recognition of title to a parcel of land situated in the Nass Valley of British Columbia. Along with the recognition of title, the Nisga'a people demanded that the federal government participate in negotiating treaty and self-government settlements. For the Aboriginal people of the Nass River Valley, their struggle has been one marred by disappointments and setbacks. Through a long tumultuous period, which saw Nisga'a chief Frank Calder and the Nisga'a Tribal Council initiate litigation against the Crown, the Nisga'a people fought for their rights. ${ }^{324}$ In 1973, the Calder case went before the Supreme Court, but it was not until three years after the fact that the federal government agreed to begin the process of negotiating a settlement with the Nisga'a Tribal Council. (See Chapter 2 for details of the Calder case).

In 1976, Canada began negotiating with the Nisga'a Tribal Council and eventually signed a bilateral framework agreement in $1989 .{ }^{325}$ In 1990, British Columbia formally joined the process, and in 1991, the three parties signed a framework agreement which identified the topics for substantive negotiation toward the Agreement-in-Principle (AIP).

\footnotetext{
$324 \quad$ Indian and Northern Affairs Canada, Chronology of Events Leading to the Final Agreement with the Nisga'a Tribal Council, online: INAC $<$ http://www.inac.gc.capr/agr/nsga/chrono e.html $>$ (last modified: 14 July 2000).

${ }_{325}$ A framework agreement is defined as "the first stage of negotiations, when the governments involved and the Aboriginal group agree on which issues are important. At this point, the parties usually set themselves deadlines for reaching an agreement-in-principle." Indian and Northern Affairs Canada, Comprehensive Claims Information Booklet, online: INAC $<$ http://intra/inac/docs/aboutthedepartment/headquarterssectors/claims\&indian government $>$ (last modified: 29 April 2000).
} 
Between 1992 and 1998, the parties conducted over 500 consultation meetings and public events concerning the Nisga'a negotiations.

An AIP was signed on March 22, 1996, forming the basis for the first modern-day treaty in British Columbia. On August 4, 1998, the parties initialled the final agreement. The Agreement calls for a payment of $\$ 190$ million in cash to the Nisga'a and the establishment of a Nisga'a Central Government with ownership of and self-governing rights over and throughout approximately 2000 square kilometres of land in the Nass River Valley. The agreement also outlines the Nisga'a ownership of surface and subsurface resources on Nisga'a lands and spells out entitlement to Nass River salmon stocks and wildlife harvests. ${ }^{326}$

\section{B. Certainty Provision of the Nisga'a Final Agreement}

The 252 page document (without appendices) exhaustively sets out the rights and benefits of the Nisga'a people. In the $N F A$, which came into effect almost 22 years after the signing of the $J B N Q A$, the method of achieving certainty shifted from a 'surrender and extinguishment' model to a 'modified rights' model. Unlike the $J B N Q A$, which provides for certainty yet does not explicitly use the wording, certainty terminology is readily apparent throughout this document. Also, unlike the $J B N Q A$, the Nisgá' a Final Agreement does not include a surrender or extinguishment clause, per se. For example, the preamble of the Agreement signifies the change in approach by stating:

WHEREAS the Parties intend their relationship to be based on a new approach to mutual recognition and sharing, and to achieve this mutual recognition and sharing by agreeing on rights, rather than by the extinguishment of rights; and

WHEREAS the Parties intend that this Agreement will provide certainty with respect to Nisga'a ownership and use of lands and resources, and the relationship of federal, provincial and Nisga'a laws, within the Nass Area.... ${ }^{327}$

\footnotetext{
In the $J B N Q A$, sub-surface and surface rights to resources are held and controlled by the Québec government.

$N F A$, supra note 302 at preamble.
} 
For the Nisga'a, who did not wish to extinguish or surrender any rights, the modification model provided the degree of satisfaction described by Hamilton by "assuring that issues have been dealt with to everyone's satisfaction and their rights are protected in the treaty" ${ }^{328}$ In addition, the modified rights approach was the first model that reflected an Aboriginal perspective of rights through a mutual recognition agreement.

Paragraphs 2, 3,\& 4 affirm that all parties are bound by the Agreement, and all parties "are entitled to rely on this Agreement". ${ }^{329}$ The NFA thereby became the final settlement identifying Aboriginal rights and title, for which no further agreement of these rights and title can be sought or achieved. ${ }^{330}$

Nisga'a lands consist of 1, 992 square kilometres of land, which is home to all four Nisga'a villages, the New Aiyansh, Gitwinksihlkw, Laxgalt'sap and Gingolx. As in the $J B N Q A$, the lands in the $N F A$ were broken down into categories. Unlike the Cree and Inuit, the Nisga'a Nation owns the "full" fee simple estate to lands in Category A, which is the "most complete interest in land that can be owned by any subject of the Crown"331. This created greater certainty for Nisga'a, since with "full" fee simple ownership the Nisga'a Nation can sell, lease or grant a right of way to the land, and own all mineral and forest resources. This notion of "full" fee simple ownership is in keeping with the Delgamuukw decision, which will enable Nisga'a residents to eventually possess lands in fee simple. In Category B lands the ownership title is "limited" fee simple, due to the fact that these lands are transferred to the Nisga'a government for the purposes of the economic development. ${ }^{332}$ 
Nisga'a Category A and B lands are subject to expropriation under federal legislation, as long as a suitable replacement can be found, but only Category B lands can be expropriated under provincial legislation. The Nisga'a Lisims Government ${ }^{333}$ must also consent to the selling or leasing of submerged lands that would impact or affect the Nisga'a lands or treaty provisions.

Under the heading of 'Representation and Warranty" (para 5), the Nisga'a Nation, as they are referred to under the agreement, enter into the $N F A$ as a collective group and are therefore entitled to "Aboriginal rights including Aboriginal title in Canada, or any claims to those rights based on their identity as Nisga'a". ${ }^{334}$ This section provides certainty by recognizing the Nisga'a Nation as a group who can enter into an agreement with legal rights.

The $N F A$ also outlines a modification and release provision as an effort to provide greater certainty and predictability to all parties. Paragraph $24 \& 25$ states that any Aboriginal rights or title that were in existence prior to the signing of the agreement are now modified by it and can continue to be modified as outlined by the agreement. Under the heading of 'Release' (para $26 \& 27$ ), two release provisions have been put in place.

The first is an 'immediate release' in which the Nisga'a Nation releases any rights and title not detailed in the Final Agreement. The second releases Canada, the province of British Columbia and/or any other third party from liability "prior to the effective date of the Final Agreement". 335

\footnotetext{
$333 \quad$ Under the definition section of the Nisga'a Final Agreement, the Nisga'a Lisims Government refers to "the government of the Nisga'a Nation" described in the Nisga'a Constitution. at 12. $334 \quad N F A$, supra note 302 at para 5 .

Ibid. at para 27. The NFA back up release, where rights are released in case the modification clause fails, reads:

If, despite this Agreement and the settlement legislation, the Nisga'a Nation has an Aboriginal right, including Aboriginal title, in Canada, that is other than, or different in attributes or geographical extent from, the Nisga'a section 35 rights as set out in this Agreement, the Nisga'a Nation releases that Aboriginal right to Canada to the extent that the Aboriginal right is other than, or different in attributes or geographical extent from, the Nisga'a section 35 rights as set out in this Agreement.
}

The Nisga'a Nation releases Canada, British Columbia and all other persons from all claims, demands, actions, 


\section{Summary}

The Nisga'a model of certainty has been touted as a marked departure from the "cede, release and surrender" provisions set out in the thirteen agreements signed before it (see appendix 5). In using a modified rights approach instead of an extinguishment, the Nisga'a Final Agreement appears to be in keeping with the fundamental principles of achieving certainty as articulated by Hamilton (ie., satisfaction amongst the parties and the protection of rights and title). For example, the agreement allows for full fee simple title to the land, thereby ensuring their land is recognized and respected by all of Canada, as well as governing the future of their relationship to the land and its resources, which was important for the Nisga'a, while clearly defining rights and title, a requisite for the federal government.

The $N F A$, like the $J B N Q A$, has been criticized for the model used to achieve certainty. Aboriginal groups such as the Interior Alliance and the AFN have argued that the modification model is a "sheep dressed in wolf's clothing", since it still contains a back up release (to be discussed in section D). Other groups argue that the holding of lands in fee simple is also problematic since it requires that taxes now be paid on those lands, which could result in negative financial impacts on a community.

On the other hand, the $\mathrm{BC}$ government and the $\mathrm{BC}$ Business Council have endorsed the certainty model of modification. In March 2004, the BC Business Council amended its original position which stated, "to avoid confusion and inconsistency, all treaties should include the same language around certainty" to now read "the Principals in the BC treaty process must develop and agree on the legal technique for achieving certainty and, in our view, this technique must be used in all treaties to ensure consistent

or proceedings, of whatever kind, and whether known or unknown, that the Nisga'a Nation ever had, now has or may have in the future, relating to or arising from any act, or omission, before the effective date that may have affected or infringed any Aboriginal rights, including Aboriginal title, in Canada of the Nisga'a Nation. 
legal regimes and a stable environment throughout British Columbia". ${ }^{336}$

\section{CASE STUDY 3}

\section{The Tlicho Agreement}

"I am honoured to be here to witness history in the making. We have come full circle from the day I shook hands here with Grand Chief Bruneau many years ago. It is with great admiration and respect that I congratulate the Tlicho people on this momentous step in taking even greater control of their future. ${ }^{1337}$

\section{Jean Chrétien}

\section{A. Background}

In 1921, then Chief Monfwi signed Treaty 11 on behalf of the Tlicho (formerly known as the Dogrib) of the North Slave in the Northwest Territories. On August 25, 2003, eighty-two years later on the anniversary of Treaty 11, representatives of the Dogrib Treaty 11 Council, the Government of Northwest Territories (GNWT) and the government of Canada signed the Tlicho Agreement. Prior to the signing, the Tlicho approved the Agreement by way of a successful ratification vote in June 2003 and subsequently passed legislation on October 10, 2003 by the GNWT. ${ }^{338}$

While the Tlicho negotiations, unlike the Cree and Nisga'a, was not born out of litigation, it has its own unique set of difficulties and history. In 1921, Canada and the Dogrib signed Treaty $11 .{ }^{339}$ Approximately 55 years later INAC agreed to enter into a comprehensive land claim negotiation with the signatories from Treaty 8 and Treaty 11

\footnotetext{
$336 \quad$ British Columbia, Two Perspectives on Certainty, BC Treaty Commission, Venture into a Treaty World, by Jerry Lampert, (British Columbia, March 2004) at 18. [Emphasis Added].

${ }_{337}$ Indian and Northern Affairs Canada, News Release: "Historic Tlicho Land Claim and SelfGovernment Agreement Signed Today", (25 August 2003) online: INAC < http://www.aincinac.gc.ca/nr/prs/m-a2003/2-02364 e.html > (last modified: 23 April 2004) Bill C-14, An Act to give effect to a land claims and self-government agreement among the Tlicho, the Government of the Northwest Territories and the Government of Canada, to make related amendments to the Mackenzie Valley Resource Management Act and to make consequential amendments to other Acts, 1st Sess., $38^{\text {th }}$ Parl., 2004 (third reading 7 December 2004). Bill C-31, "An Act to give effect to a land claims and self-government agreement among the Tlicho, the Government of the Northwest Territories and the Government of Canada, to make related amendments to the Mackenzie Valley Resource Management Act and to make consequential amendments to other Acts", was introduced before Parliament on March 31, 2004 but died on the order paper when the elections where called in June 2004

339 For a complete version of Treaty 11 visit INAC's website online: INAC <http://www.aincinac.gc.ca/pr/trts/trtyll e.html.> (last modified: 12 December 2004).
} 
(the Dene and Métis), due to the fact the commitments, on the part of the federal government, for land entitlement were never properly fulfilled. In 1990, the parties initialed a final agreement and proceeded to ratify the agreement. The agreement was rejected by the Dene and the Métis since it required them to cede, release and surrender any undefined rights and was void of substantive self-governing provisions. The Gwich'in and the Sahtu Dene and Métis, who were also involved in the negotiation process, asked that they move forward with signing their own agreement and reached a settlement in 1992 and 1994 respectively.

In 1992, the Tlicho began negotiations with the federal and territorial governments. Negotiations were briefly put into abeyance in 1995 in order that exploratory discussions could be held in light of the release of Canada's Inherent Right Policy, which set the stage for self-government agreements. In 1997, with a new mandate in hand, the parties began negotiating a comprehensive and self-government agreement concurrently. Five years later, the Tlicho initialized a final agreement, but unlike other agreement signatories, who began the ratification process almost immediately, the Tlicho opened up the agreement for public consultation. As a result of this process, they were able to reach historic overlap agreements with both the Deh Cho and the Akaitcho First Nations.

Under the Tlicho Agreement, which is considered an extension of Treaty 11, the Tlicho beneficiaries will acquire 39, 000 square kilometers of land, including subsurface rights, owning approximately $3 \%$ in fee simple. Furthermore, the Tlicho beneficiaries are slated to receive $\$ 90$ million to be paid over fourteen years, as well as a percentage of resource royalties. This money will be used as an investment fund to promote social, cultural, educational and economic development in the Tlicho area. 


\section{B. Certainty Provisions in the Tlicho Agreement}

Like the final agreements signed before it, the Tlicho Agreement, consisting of 208 pages, sets out the rights and benefits of the four Tlicho communities: Behchoko (Rae-Edzo), Wha Ti (Lac la Martre), Gameti (Rae Lakes) and Wekweti (Snare Lake). However, unlike its predecessors, the Tlicho Agreement has been touted as a new model of certainty known as the non-assertion model. The then Minister of INAC, Robert Nault, described the new model as "using a recognition of the reverse, that there are certain rights that are not defined that may be defined in the future and the way the certainty is structured is that it allows for an orderly process to bring those rights to the treaty". ${ }^{340}$ A non-assertion model means that the Aboriginal group will not assert a right not contained within the treaty, although the right can still exist. However, the nonassertion model also allows the Tlicho to seek non-land rights, currently not contained within the agreement, from the government, if they feel they are entitled to assert a nonland right by entering into negotiations for rights to be exercised. If the government refuses, the Tlicho may turn to the courts for a determination.

The new certainty provisions read:

Except as provided in s.2.6.1, the Tlicho will not exercise or assert any Aboriginal or treaty rights, other than:

(a) any rights set out in the Agreement; or

(b) the Treaty 11 rights respecting annual payments to the Indians and payments of the salaries of teachers to instruct the children of the Indians. ${ }^{341}$

Section 2.6.3 states for greater certainty:

(a) 2.6.1 prevents a Tlicho Citizen from exercising or asserting any Aboriginal or treaty rights other than those referred to in 2.6.1(a) and (b); and

(b) 2.6.2 does not prevent a Tlicho person who is not a Tlicho Citizen from exercising or asserting any Aboriginal or treaty right held by another Aboriginal people of which that person is a member. ${ }^{342}$

\footnotetext{
340 Windspeaker News, "Certainty' model causes concern" (2002) online: $<$ http://wwwammsa.com/windspeaker/topnews-Oct-2002.html >, (date accessed: 15 December 2004) at 3. Tlicho Agreement, supra note 303 at s.2.6.1. $342 \quad$ Ibid. at s.2.6.3
} 
Another significant departure in the Tlicho Agreement from past agreements is the preamble, which is the closest any agreement has come to adopting Hamilton's model for achieving certainty, reads ${ }^{343} \&^{344}$ :

\begin{tabular}{|l|l|}
\hline \multicolumn{1}{|c|}{ Tlicho Agreement } & \multicolumn{1}{c|}{ Hamilton Report } \\
\hline $\begin{array}{l}\text { WHEREAS The Thicho is an Aboriginal } \\
\text { people of Canada that has used and occupied } \\
\text { lands in and adjacent to the Northwest } \\
\text { Territories from time immemorial; }\end{array}$ & $\begin{array}{l}\text { WHEREAS the (Aboriginal group) has used } \\
\text { and occupied lands and resources in the } \\
\text { Treaty Area since time immemorial. }\end{array}$ \\
\hline $\begin{array}{l}\text { WHEREAS the Constitution Act, 1982 } \\
\text { recognizes and affirms the existing Aboriginal } \\
\text { and treaty rights of the Aboriginal peoples of } \\
\text { Canada; }\end{array}$ & $\begin{array}{l}\text { WHEREAS the parties to this treaty agree } \\
\text { the (Aboriginal party) has Aboriginal rights } \\
\text { in the Treaty Area. }\end{array}$ \\
\hline $\begin{array}{l}\text { WHEREAS the Parties have negotiated this } \\
\text { Agreement in order to define and provide } \\
\text { certainty in respect of rights of the Tlicho } \\
\text { relating to land, resources and self- } \\
\text { government. }\end{array}$ & $\begin{array}{l}\text { WHEREAS the parties wish to achieve } \\
\text { certainty with respect to the ownership and } \\
\text { use of lands and resources dealt with in the } \\
\text { treaty. }\end{array}$ \\
\hline
\end{tabular}

Unlike the $J B N Q A$ and the $N F A$, the lands described in the Tlicho Agreement are not classified as categories, instead they are referenced as geographical areas. The first area, the Monfwi Gogha De Niitlee, is the largest of the four areas and encompasses all the Tlicho communities. Under the agreement, the Tlicho will exercise most of their rights within the Monfwi Gogha De Niitlee, including year round harvesting rights.

The second, known as Wekeezhii, is a resource management area which is bordered by the Sahtu and Gwich'in Land claim settlement areas. ${ }^{345}$ The rolling surrender clauses in the Sahtu and Gwich' in Agreements will be amended to non-assertion clauses in order that they conform to the Tlicho Agreement.

The third area is known as the Tlicho Lands. The Tlicho Government, on behalf of the Tlicho citizens, holds fee simple title to approximately $3 \%$ of the Tlicho land within the settlement areas. As with the Nisga'a Nation, the Tlicho can sell, lease or

\footnotetext{
343 Tlicho Agreement, supra note 303 at 1 . This represents only excerpts from the Preamble. $344 \quad$ Hamilton, supra note 5 at 103.

345 The Wekeezhii Renewable Resources Board will be responsible to oversee the management of wildlife and habitat. Furthermore, the Board will make recommendations about wildlife, forest and plant resources and commercial activities.
} 
grant a right of way to the land, and own all mineral and forest rights on Tlicho lands.

Section 18.1 .7 notes:

Tlicho title is held in the form of fee simple title. The form of title shall not be construed as having the effect of extinguishing any rights recognized and affirmed by section 35 of the Constitution Act, 1982. Title held by the Tlicho Government to Tlicho lands does not give title to water in, on, or under the lands. ${ }^{346}$

Tlicho community lands refer to those parcels of land, owned in fee simple by the various Tlicho communities, but excludes land owned by the Tlicho government. All lands within the settlement are still subject to expropriation under federal legislation, provided that suitable compensation is paid in the form of money or the replacement of lands. Third party interests with legal tenure will be protected.

The fourth area is called Ezodziti. This area is not owned by the Tlicho, nor do hunting and harvesting rights exist within this area but it is protected due to historical and cultural importance for the Tlicho Nation and all Canadians. ${ }^{347}$

Like the NFA, section 2.6 .9 of the Tlicho Agreement also contains a back up release which reads:

If 2.6.1 or 2.6 .2 is not enforceable in relation to a land right, and that

(a) results in the imposition on government or any person of any obligations, related to that right, to the Tlicho or any person who is not to exercise or assert it;

(b) affects the ability of Tlicho Citizen, the Tlicho First Nation or the Tlicho Government to exercise and enjoy all their rights, authorities, jurisdiction and privileges that are set out in the Agreement; or

(C) affects the ability of any other person or government to exercise and enjoy all the rights, authorities, jurisdictions and privileges they would have if that right did not continue to exist, the Tlicho cede, release and surrender, as of the effective date, that land right to the extent required to achieve the purpose in 2.6.4. ${ }^{348}$

Furthermore, section 2.6 .10 reads:

If the continued existence of a land right, that under 2.6 .1 or 2.6 .2 is not exercisable or assertable,

(a) results in the imposition on government or any person of any obligations, related to that right, to the Tlicho or any person who is not to exercise or assert it;

(b) affects the ability of Tlicho Citizen, the Tlicho First Nation or the Tlicho Government to exercise and enjoy all their rights, authorities, jurisdiction and privileges that are set out in the Agreement; or

Tlicho Agreement, supra note 303 at s.18.1.7.

Ibid. at s.17.6.1

Tlicho Agreement, supra note 303 at s. 2.6.9 . 
(c) affects the ability of any other person or government to exercise and enjoy all the rights, authorities, jurisdictions and privileges they would have if that right did not continue to exist, the Tlicho cede, release and surrender, as of the effective date, that land right to the extent required to achieve the purpose in 2.6.4. ${ }^{349}$

\section{Summary}

The non-assertion model is now the second alternative model to the "cede, release, surrender" model to be accepted by the Crown. However, not everyone is pleased with the new model. Immediately upon the initialling of the agreement, the Akaitcho First Nation in Treaty 8 voiced concerns over the model in which they felt it was nothing more than an extinguishment model. At the other end of the spectrum, Members of the House of Commons also challenged the non-assertion model as inadequate, noting that they felt the agreement failed to reach a state of finality, and thus certainty, that other agreements, more notably Nisga'a, had achieved. ${ }^{350}$

\section{Release}

The final areas that must be examined in relation to the three certainty models examined above are the release clauses. All final settled land claim agreements require that the Aboriginal group releases undefined rights and title, and also releases Canada, the province and/or third parties from liability in order to secure a greater amount of certainty. The rationale has been that without this release, Aboriginal groups could potentially claim to have rights and title to an area outside of the settled agreement. Thus, it has been argued that by releasing undefined rights and title, Canada's, the provincial government's, and third party rights and interests in settling a claim are also represented. Furthermore, the Crown has always insisted on these provisions.

The question then becomes does a release from liability provision take away from achieving certainty, or does it attempt to secure greater certainty since the parties to the

\footnotetext{
$349 \quad$ Tlicho Agreement, supra note 303 at s. 2.6.10.

$350 \quad$ House of Commons, Minister Andy Scott's response to various questions in Question Period on November 1, 2004.
} 
agreement have all their rights defined and have agreed that these are the rights that are in the best interest of the Aboriginal community, Canada and third parties? One must question whether or not a release from future liability and a back-up release provision is the wrong way to achieve certainty, especially in light of the fact that all parties to a land claim agreement seem to agree that the final agreement should, in some form, focus on the implementation of obligations as per the agreements.

Many, if not most legal agreements involve a cash settlement, and incorporate a release provision from future liability. These release and compensation provisions are illustrated in the tainted blood, hepatitis $\mathrm{C}$, and the various sexual abuse cases, in which individuals were compensated for past wrongs by either the provincial and/or federal government, all with a surrendering of any future claim.

In the late 1990 s and into the new millennium, the federal government shifted to a 'risk management' ${ }^{351}$ approach to assist in developing new policies/legislation, etc., to reach decisions about uncertain situations. The process followed to make a decision can vary, but it is essential that the process always starts with a clear link to the organization's objectives. However, one factor that plays an important role in the settlement of land claim agreements, and may be lacking in a risk management model, is the unique relationship that exists between Aboriginal people and the federal government.

I would argue certainty can be achieved without a back up release if an agreement acknowledges the notion of legitimacy over lands and jurisdiction; accommodates the diversity and unique socio-economic conditions of a community; has measures in place to address third party interests and economic opportunities; accounts for diversity and is flexible to assist communities in addressing their needs; and lastly is the foundation on

\footnotetext{
351 INAC defines risk management as "a conscious structured process for setting the preferred course of action in circumstances of uncertainty by: identifying, assessing, understanding, acting on and communicating risk issues. The process always starts with objectives and considers context and communications at every step." [Emphasis added]. Indian and Northern Affairs Canada, "Modern Management Practices and Assessments", online: INAC

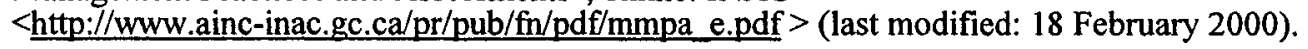


which co-operative relationships between federal/provincial/territorial governments, third parties and Aboriginal groups can build to ensure the agreement is fully implemented. If these aforementioned factors are in existence, then release provisions are redundant because safe measures are entrenched in the final agreement to ensure greater certainty.

\section{E. Summary}

Since the signing of the $J B N Q A$, the environment in which agreements are negotiated and eventually concluded has changed significantly. For example, the model of certainty has shifted from an extinguishment model, where rights that are defined in the treaty are forever lost, to a non-assertion model, where rights that may exist outside the treaty are not asserted.

While the debate rages on as to whether or not these models differ significantly, there do appear to be important differences. The $J B N Q A$ is an important document as it set the stage for modern-day treaties to exist. Valuable lessons have been learned from negotiating and implementing this treaty, and despite the criticism in relation to the extinguishment model and ongoing litigation over its implementation, 12 Aboriginal groups adopted the model to settle land claims.

The Nisga' a Final Agreement has been held up as a new model since rights are no longer ceded, released or surrendered, but instead modified as set out in the agreement. The newest model, the non-assertion model, in the Tlicho Final Agreement, recognizes that some non-land rights currently cannot be defined, but allows for the opportunity to explore/define these rights at a later date. Like its predecessors this model has been criticized; while some Aboriginal groups argue it is nothing more than extinguishment, some politicians argue that it lacks the finality the government has sought and needs in land claim agreements. ${ }^{352}$

\footnotetext{
$\overline{352}$ See Appendix 5: Comparison of Hamilton's model against the James Bay, Nisga'a and Tlicho
} Agreements. 
From these three case studies and previous chapters, we see that the negotiation and settlement of modern-day treaties is not a simple process of developing an agreement; each agreement must incorporate many unique and complex issues. The three aforementioned treaties show a progression in achieving certainty, and point us in a direction where a model of certainty can be based on a reconciliation approach that aims to restore the relationship between Aboriginal people and the Crown, while at the same time creating and maintaining healthy and sustainable communities. The reconciliation model of certainty is designed address the substantive issues faced by each community and creates objective standards that can be measured. 


\section{CHAPTER 6}

\section{A NEW APPROACH}

Land claim negotiations should look to the future and should provide a means whereby Aboriginal groups and the federal government can pursue shared objectives such as self-government and economic development. ${ }^{353}$

\section{Resolving the Uncertainty}

Previous chapters have attempted to demonstrate that the achievement of certainty through the negotiation and settlement of modern-day treaties is a complex process due to its linkages to colonialism, varying legal interpretations, provincial and third party involvement, and differences in the theoretical framework applied to achieve it. In addition, these chapters, through an examination of case studies, reports and commissions have also highlighted the differences and commonalities between the parties negotiating the settlement of land claims. These include the role of third party interests, economic investment, diversity and flexibility, cooperative relationships and recognition of rights and title.

Chapter 6 will examine the pros and cons of the fundamental principles purported in the Hamilton Report (chapter 4), in conjunction with the research findings correlated from in-person interviews ${ }^{354}$ in order to answer the overall research question: In settling

\footnotetext{
353 Land Claim Agreement Coalition, "A New Land Claims Implementation Policy", online: itk $<$ http://www.itk.ca/media/supporting-docs/landclaim-discussionpaper.pdf $>$ (last modified: unknown) at 1.

This chapter highlights the findings of the research (questionnaires and interviews) that were carried out during the period of November 2003 to November 2004. Seven interviews, which resulted in a response rate of $78 \%$, were conducted with various senior officials from Indian and Northern Affairs Canada and the Indian Claims Commission, to ascertain their views regarding the conflicting ideologies and the development of alternative models of certainty that would recognize the interests of all parties. Letters were also sent to representatives at the Assembly of First Nations and the Privy Council's Office, but despite follow up phone calls to arrange interviews, the desired meetings never took place. An introductory letter (Annex A) was sent to the proposed interviewees to assess if they would like to partake in the interview. Upon request, the interview guidelines (Annex B) were also sent to allow the individual time to review the questions. Each participant was asked to sign a consent form (Annex D) before completing the questionnaire or responding to the interview questions, and as per the agreement form (Annex E), the data collected and presented below is reported at the aggregate level and individual's identities/responses are not reported. As such, the data represents the majority of respondents and is presented in a summarized format to capture overall perspectives. The comments included in this chapter are based on a synthesis of all available information to provide a context for the development of a new model of certainty as warranted. In other instances, observations of emerging trends or issues that bear noting are presented. This information is organized according to the format of the questionnaire/interview guidelines. When necessary,
} 
treaty claims could an alternative method be developed to achieve certainty without Aboriginal groups having to cede, release, surrender, extinguish or modify any rights that exist outside the treaty?

This chapter will argue that an alternative model of certainty can be achieved through the process of reconciling the conflicting ideologies that have impeded the negotiation process. Furthermore, it will outline what I consider, based on research and interviews, to be the essential structures in attempting to achieve certainty and strengthen the relationship between the government and Aboriginal groups. In a reconciliation model of certainty these structures, which include a recognition of rights and title, Aboriginal participation in policy development and reviews; capacity building and consultation, accommodation and balanced commitments help not only the negotiation process but in the implementation of the final agreement.

\section{A. Context}

In exploration of the research questions, seven interviews were conducted that lead to the identification of five themes that share characteristics with those identified by the task forces and commissions. These themes are: 1) simplified processes, 2) evolution and flexibility, 3) stability, predictability, economic investment, 4) implementation of the treaty and 5) healthy communities.

Of those individuals interviewed, the majority felt that an alternative model of certainty could be developed without Aboriginal groups having to cede, release, surrender, extinguish or modify any rights. However, respondents also noted that this requires a shift in thinking on the part of the provinces, federal departments and central agencies that address the legal and political aspects of Aboriginal issues. Many felt that the current methods used to achieve certainty were too technical and legalistic. This conclusions and observations are further supported by the literature to assist in the construction of a new model of certainty. 
position is supported by Stevenson, who argues: "In the context of treaty discussions, the term certainty is generally used to describe a legal technique that is intended to define with a high degree of specificity all of the rights and obligations that flow from a treaty and ensure that there remain no undefined rights outside the treaty". ${ }^{355}$ As such, the first theme centres around the need for a simplified process in negotiating and settling modern-day treaties.

The majority of the respondents also noted that there was a need to examine the concept of certainty. This included: what is (meant by) certainty, what is certainty meant to achieve, and how long should certainty be achieved for - finality versus ongoing relationships. ${ }^{356}$ The majority of those interviewed also pointed to the non-assertion certainty clauses contained in the Tlicho Agreement, as a solid less offensive starting point to build upon, since it allows rights to be negotiated at a future date. ${ }^{357}$

The second theme, evolution and flexibility, noted that an essential element to the achievement of certainty was the need for growth and flexibility in the negotiation and settlement of treaties as well as related policies. ${ }^{358}$ This was linked to findings of the commissions and task forces, which noted the need for diversity and flexibility as a

\footnotetext{
$355 \quad$ Stevenson, supra note 13 at 2.

356 While no solutions were proposed, many felt that work needed to be done in this area.

357 Many respondents also noted that more flexible models were being considered, but due to the sensitivities of the negotiations, were unable to share any information on what these models might look like. What is also interesting is how many respondents noted that a new certainty model should be based on the concept of co-existence as the catalyst to build future relationships. However, many respondents noted that other governmental departments or central agencies play a role in what types of models will or will not be accepted by the Crown. As such, there appears to be a need to educate other departments/central agencies on the importance of accepting alternative models of certainty.

358 Unfortunately, a concern over the willingness, or more specifically the lack there of, of signatories/beneficiaries to participate in responding to a questionnaire was confirmed by a poor response rate. Despite repeated attempts to make contact, I only received one response back in which the group thanked me for soliciting their opinion, yet opted not to participate. This is problematic in the sense that the majority of research, commissions, task forces, etc., have clearly stated that any changes to existing negotiation processes must be done in consultation with Aboriginal groups - it is a view that I support. However, this model, like any other model, always has room for improvement and perhaps it could be used as a springboard to engage the parties in dialogue. For many groups who have been involved, are currently involved, or are familiar with the negotiation process, some of the recommendations articulated in this section will not be new - others will be.
} 
response to a cookie cutter approach to negotiating and implementing final agreements that fails to acknowledge the complexity and uniqueness of each community.

The third theme, stability, predictability and economic investment, highlights the desire of Aboriginal communities and third parties to have opportunities to participate within the settlement area. All respondents interviewed strongly agreed that certainty was very important when settling a land claim, but departed on who certainty was most important for. The majority also noted that clarity and predictability of ownership and title were necessary components to ensuring that economic development could take place in the Aboriginal community. However, some respondents further noted that the achievement of certainty was more of a benefit to Canada than to Aboriginal communities because it wanted to gain access to lands and resources. ${ }^{359}$

The fourth theme focusses on the implementation of the agreements. Through the literature and document reviews and interviews, the need was clearly expressed to fully implement the treaty obligations to avoid repeating the mistakes made with the historic treaties.

The last theme, a need for healthy communities, questioned the achievement of certainty in communities that lacked community stability at the social level. Many respondents noted that before certainty could be addressed or achieved in any community, there was a need to examine social conditions. The concerns expressed are supported by numerous studies and reports on Aboriginal peoples in comparison to the rest of Canada, and even to developing countries. ${ }^{360}$ As noted throughout this thesis, imposed colonial structures have often disconnected Aboriginal people from their traditional ways, languages and lands. This has resulted in communities with high

\footnotetext{
$359 \quad$ Many respondents felt that the current methods of certainty address the needs of Canada, to allow for economic development, thus certainty equates to the government being able to exploit the lands and resources.

360 For examples please visit the following websites: Health Canada, INAC, United Nations, and Amnesty International.
} 
unemployment rates, low educational attainment rates, an over-representation of Aboriginal people in the judicial system, high risk of poor health, premature death, chronic disease, youth suicide and lack of adequate housing. This raises an interesting point as to whether or not certainty can be achieved in communities where such social discord exists.

\title{
B. The Reconciliation Model
}

\author{
The world is closing in \\ Did you ever think \\ That we could be so close, like brothers \\ The future's in the air \\ I can feel it everywhere \\ Blowing with the wind of chang $e^{361}$
}

History has shown that certainty is a powerful tool in so far as it has resulted in the extinguishment, surrender, ceding and modification of rights and title. For their part, the courts have stated that: Aboriginal title is sui generis, and cannot be transferred, sold or surrendered to anyone other than the federal Crown. Aboriginal title cannot be put to uses that may be irreconcilable with the nature of the occupation of that land and the relationship that Aboriginals have with the land; and nothing about the title "should be taken to detract from the possibility of surrender to the (federal) Crown in exchange for valuable consideration. If Aboriginal people wish to use their lands in a way that Aboriginal title does not permit, then they must surrender those lands and convert them into non-title lands to do so". ${ }^{362}$

For Aboriginal groups/communities/organizations, certainty is a means of formalizing or legitimizing title, rights and benefits that they have always known to exist.

\footnotetext{
361 The Scorpions "Wind of Change" (1990) online: <http://en.wikipedia.org/wiki/Wind of Change $>$ (date last accessed: 15 May 2007).

Delgamuukw, supra note 2 at para 125-132.
} 
Certainty is meant to build ongoing relationships and not bring about finality. ${ }^{363}$ More importantly, as models currently stand, the only party to have rights extinguished, surrendered or modified happens to be Aboriginal beneficiaries in the treaty process.

The proposed model challenges the current definition of certainty and suggests that certainty may be achieved by building on common objectives beyond land and resources, and taking into account the social and cultural aspects within the community to reconcile differences and build future relationships. ${ }^{364}$ While this new model is restricted to addressing Aboriginal rights and title via treaties, it is more than a mere change in terminology, it also calls for a change in how the model is viewed and applied. Certainty is not a legal process that takes the form of cede, release, surrender nor should it ever be viewed as a finality (e.g. an end to the relationship). The model I propose is a reconciliation model of certainty that addresses both the legal and political objectives of a treaty. It is a tool to be used throughout the negotiation process with an objective aimed at restoring the relationship between the Crown and Aboriginal peoples through the settlement of difference as opposed to severing Aboriginal rights and title.

In analysing the ideal framework to achieve certainty, this paper proposes that the fundamental principles articulated in the Hamilton Task Force Report should be adopted in the negotiation and settlement of treaties. These principles encompass a recognition of rights; mutual assurances; mutual respect and trust; fair and balanced commitments; enforceability of the treaty commitments/obligations; and the opportunity, at a future date, to negotiate rights that are not contained in the treaty upon mutual agreement.

\footnotetext{
363 Of those interviewed some respondents expressed that although past techniques may not be desirable today, the agreements, which include cede, release, surrender and modification, were concluded and signed based on informed consent. Other respondents noted that in absence of alternative methods, Aboriginal groups were left no choice but to cede, release, surrender or modify their rights. 364 For many groups who have been involved, are currently involved, or are familiar with the negotiation process, some of the recommendations articulated in this section will not be new - others will be. For years, Aboriginal communities have argued that treaties are not the only vehicle to solve the ambiguity associated with Aboriginal rights and title; however, when they are used, treaties must be viewed as a tool that can assist in achieving broader objectives. Presentation to the Select Standing Committee on Aboriginal Affairs by the Fraser Valley Treaty Advisory Committee, Clint Hames the Mayor of Chilliwack and Chair of the Fraser Valley Treaty Advisory Committee (October 17, 2001) at 5.
} 
Furthermore, Hamilton was adamant that absolutely no model that incorporates surrender is acceptable. To this latter point Hamilton noted that:

I suggest that Aboriginal rights should not be and do not have to be surrendered under any circumstance whatsoever in order to either aid negotiation or to achieve equality. ${ }^{365}$

As with the negotiation process itself, no one model of certainty can be touted as the "perfect model", each treaty has its own unique challenges. Any certainty model must account for the social, cultural and physical aspects of a community. Thus, treatymaking is as much about the substantive issues of each community as it is about the negotiation process.

In order for a new model to work to achieve certainty that recognizes the interests of certain parties, without Aboriginal groups having to cede, release, surrender, extinguish or modify any rights that exist outside the treaty, a few points must be addressed. First, certainty, I would argue, is not what you achieve the moment you sign a treaty or even a clause contained within a treaty. Instead, certainty is the final outcome once all the pieces are in place and brings about clarity and predictability but more importantly, certainty equates to reconciling Aboriginal rights and title with the ultimate objective of creating healthy and sustainable communities.

In 1996, RCAP recommended that:

"governments and the Canadian people undertake a comprehensive and unflinching assessment of the unstable foundation of the relationship between Aboriginal people and other Canadians, arguing that we can no longer afford merely to manage the continuing crisis in the relationship by mediating potential areas of conflict while leaving unaltered the foundation on which that conflict inevitably arises. Clearly, restoring the honour to the Crown, while rebuilding Aboriginal communities, is needed." $" 366$ 
A reconciliation ${ }^{367}$ model is in keeping with the concepts proposed by Aboriginal groups and RCAP as the catalyst for changing the relationships between Aboriginal groups and the Crown. ${ }^{368}$ It moves away from a stringent "all or nothing" legalistic definition and gravitates towards a flexible model allowing for evolution, relationship building and takes into consideration the uniqueness of the current social situation within a community. Certainty must restore to friendship the relationship between the Crown and Aboriginal peoples through the settlement of differences as opposed to resigning Aboriginal people to sever their connection to land and rights (e.g. hardship). A reconciliation model engages Aboriginal people and the Crown in the negotiation of agreements that encompass the settlement of lands, resources and social issues and can spark healthy dialogue between Aboriginal and non-Aboriginal people. ${ }^{369}$

In formulating a new model of certainty, parallels can be drawn between the treaty making process, which encompasses the negotiating, signing and implementing of a treaty, and the building of a customized home. My conceptualization moves away from the idea of "mass producing" homes in which the models that can be chosen from are predetermined, to a model that results in a unique home that caters to the specific needs of each individual buyer. As such, the customization addresses the diversity and flexibility that is sought by Aboriginal groups to accommodate the differences amongst the groups. It also addresses the concerns raised by federal departments, as customization allows for processes/mechanisms to be in place to support their mandates but also

\footnotetext{
$367 \quad$ According to the Webster's dictionary reconcile is defined as: To restore to friendship or union; to bring to regard with resignation or submission (e.g., to reconcile oneself to hardship); to make or prove consistent; to adjust settle (e.g., differences). Merriam-Webster's Dictionary, online: Merriam-Webster $<$ http://www.m-w.com/> (date accessed: 25 April 2005) s.v. reconcile.

${ }_{368}$ See: United Nations, Commission on Human Rights, Human Rights and Indigenous Issues: Report of the Special Rapporteur on the situation of human rights and fundamental freedoms of Indigenous people, by Mr. Rodolfo Stavenhagen, 2 December 2004. Assembly of First Nations, "Assembly of First Nations" Critique of Federal Land Claims Policies" (1990), online: ubcic at $\mathrm{p} 1<\mathrm{http} / / \mathrm{www}$.ibcic.bc.ca/afn.htm $>$ (last modified: 2 April 2000). Canada, Royal Commission on Aboriginal Peoples, Vol. 2, Restructuring the Relationship, (1996) online: Indian and Northern Affairs Çanada <http://www.aincinac.gc.ca/ch/rcap/sg/sgmm e.html $>$ (last modified: 24 December 2003 ) at 1.

See Appendix 6 for a comparison of the 'Reconciliation Model of Certainty' to the key principles laid out in Hamilton's model.
} 
accounts for the varying degree of social, economic, and political differences in Aboriginal communities. This is not to suggest that the attempt to achieve certainty is in any way a linear process, however, it does imply that certain structures must be in place before the finishing work can occur. Mutual respect and trust, which are the support beams of the conceptual edifice, must be evident throughout the process if the relationship is to stand up over time.

\section{A Home for Certainty}

\section{Breaking Ground - Breaking Barriers}

In 2004, the Centre of Research and Information on Canada (CRIC) released its annual survey results in Portraits of Canada. According to the CRIC, the majority of Canadians do not rank improving the quality of life of Aboriginal Canadians as a high priority. ${ }^{370}$ In 2003 , the results from the CRIC report showed that " 3 of every 4 Canadians think that it is beneficial to all Canadians that the distinctive culture of Aboriginal peoples remain strong". ${ }^{371}$ However, Canadians were divided on the issue of Aboriginal land claims and rights. ${ }^{372}$ More specifically, while $45 \%$ of respondents felt that claims put forth by Aboriginal people in relation to lands and rights were valid, 49\% disagreed. ${ }^{373}$ In relation to settling outstanding land claims and self-government issues, $53 \%$ of Canadians supported the process, while $42 \%$ of Canadians "viewed that it would be better to do away with Aboriginal Treaty rights and treat Aboriginal people the same as other Canadians". ${ }^{374}$

It is important that Aboriginal groups/organizations/communities and the

\footnotetext{
$370 \quad$ Centre of Research and Information on Canada, "New Findings on Canadians' Attitudes to Improving Aboriginal Quality of Life, New Release (11 November 2004). Canadians ranked Aboriginal issues 11 out of 12 possible choices.

371 Opinion Canada, "Canadians want strong Aboriginal cultures but are divided on Aboriginal rights", (2003) Vol. 5 online: Opinion Canada <http://www.opinion-canada.ca/en/articles> (date accessed: 17 January 2005).

372 Ibid.

$373 \quad$ Ibid.

$374 \quad$ Ibid.
} 
federal/provincial/territorial governments continue campaigning to educate the media and public as to the importance of addressing and resolving Aboriginal rights and title in Canada. ${ }^{375}$ With a high number of outstanding land claims still to be settled in highly populated areas such as Quebec, Eastern Ontario and British Columbia, it will be important for all parties to understand the history and issues in order to advance the negotiation process. As such, education and the dissemination of information form the stable ground into which the foundation is poured.

\section{Foundation - A Matter of Trust}

As in any house, a solid foundation must be laid. The foundation must be strong for if it starts to crack or crumble, it puts a stress on the entire house, which can lead to additional problems like the buckling of other structures, much like mistrust can hinder the negotiation or implementation process. This requires a shift in the Crown's position towards the recognition of Aboriginal rights and title. Key elements of the foundation include a recognition of rights and title, trust, consultation and capacity building.

Acknowledging that Aboriginal title exists and then attempting to remove it through surrender provision does not add an air of legitimacy to the process, nor does it attempt to reconcile the inequality. ${ }^{376}$ Relationships cannot be built if the premise is that

375 Federal departments such as INAC, Health Canada, Parks Canada and Heritage and all 5 major Aboriginal organizations (The Assembly of First Nations, Congress of Aboriginal Peoples, Native Women's Association of Canada, Métis National Council and the Inuit Tapiriit Kanatami) have websites that are regularly updated and post information about Aboriginal people in Canada.

${ }_{376}$ DIAND, supra note 146 at 11 and 12 . According to the Comprehensive Land Claims Policy

(CLCP), the federal governments policy that addresses land claims, treaties are conducted under sentiment that they are defining relationship by clearing and concisely defining rights and seeks an alternative to extinguishment but requires certainty with respect to lands and resources.

The problem with this position is that acceptable options under the policy are:

(1) the cession and surrender of Aboriginal title throughout the settlement area in return for the grant to the beneficiaries of defined rights in specified or reserve areas and other defined rights applicable to the entire settlement area; or

(2) the cession and surrender of Aboriginal title in non-reserved areas, while;

1. allowing any Aboriginal title that exists to continue in specified or reserved areas;

2. granting to beneficiaries defined rights applicable to the entire settlement area.

In the Guerin and Delgamuukw decisions the court speaks of a fiduciary relationship between the Crown and Aboriginal people based on the need for the Crown to act honourably. The Haida and Taku River decisions note that the duty to consult is grounded in the honour in the Crown. 
Aboriginal rights and title exist in Canada, yet in signing a treaty, they have to sever their connection to the land as it makes the assumption that the parties are not on equal footing in the negotiation process. Furthermore, this supports the notion that certainty is desired by governments as it allows them the necessary access to the lands and resources. The treaty should be the framework for building co-operative relationships and ensuring that obligations arising from the treaty will be fulfilled.

Trust is an essential component in the reconciliation model of certainty. The adversarial system has played an important role in advancing the Aboriginal agenda and debunking the notion of paternalism by acknowledging that a special relationship exists between Aboriginal people and the Crown (i.e., Guerin, Delgamuukw, Haida and Taku River). ${ }^{377}$ The Haida and Taku River decisions stated that the federal and provincial governments have a legal duty to consult and, if appropriate, to accommodate when the Crown has knowledge of the potential existence of Aboriginal rights or title and contemplates conduct that might adversely affect them. The duty to consult with Aboriginal people and accommodate this interest is grounded in the honour of the Crown; making it the first time that the honour of the Crown is viewed as a source of legal duty.

For Aboriginal communities in $\mathrm{BC}$, their concerns and mistrust were validated by the recent actions of the Liberal government of $\mathrm{BC}$, which has focused on the achievement of certainty for businesses and industry as opposed to certainty for Aboriginal communities. For instance, despite court cases such as the Haida and Taku River Tlingit, in which the courts dealt with the duty to consult and accommodate, the BC government has unilaterally amended forestry, mining and land-use legislation as a means of avoiding or dismissing these duties towards First Nations. ${ }^{378}$ This is very disheartening 377 In the Guerin and Delgamuukw decisions the court speaks of a fiduciary relationship between the
Crown and Aboriginal people based on the need for the Crown to act honourably. The Haida and Taku
River decisions note that the duty to consult is grounded in the honour in the Crown.
378 W. Horter, "The Crown's Quest for 'Certainty"' Dog Initiative (22 May 2004) online:
<http://www.dogwoodinitiative.org/Pages/newsroom/bulletin.php?filepath=http://www.dogwoodinitiative.o
rg/bulletin/archives/000417.html> (date accessed: 10 December 2004). 
in light of the fact that $\mathrm{BC}$ has the largest number of negotiating tables at various stages in the negotiation process, and after 11 years of negotiating treaties, has only reached one final agreement and four agreements-in-principal. Just as disheartening is the fact that the $\mathrm{BC}$ government's actions are in stark contrast to the recommendations made by the task forces and commissions as noted in Chapter 4. Such actions do nothing to support and foster trust in the relationship.

Though placed in the foundation, consultation must be evident throughout the model if trust is to be established and certainty achieved. While no legal right exists on the part of third parties to do so, they must view consultation as fundamental to building relationships with Aboriginal groups; so too must the federal and provincial/territorial governments. The same also applies for Aboriginal groups who should reciprocate and consult and if necessary, accommodate third party concerns/issues. In doing so, it exemplifies a commitment on behalf of all parties to build relationships.

This leads to another important aspect of the foundation - the ability of Aboriginal groups to be active participants in policy making processes that directly relate to Aboriginal issues. The reports examined in Chapter 4 agreed that any policy designed to address Aboriginal rights and/or title must be flexible in order to accommodate differences amongst the groups, not only in the various stages of negotiations, but in the final agreement as well. Any policy, like the CLCP, must allow for evolution, adjusting itself from time to time in the way of renewed rights, to account for changing social and legal aspects, and to reconcile accordingly.

The ability of Aboriginal communities to participate meaningfully in the negotiation and settlement of land claim agreements is fundamental. Increased involvement and strengthened capacity contribute to the development of more appropriate responses to socio-economic issues faced by Aboriginal people. As more Aboriginal 
people engage in a meaningful way in regard to the negotiation, settlement and administration of issues that directly affect them, a better understanding of Aboriginal values, needs and aspirations will evolve, contributing to the conditions necessary for sustainable change within the mainstream system.

In order for this to happen however, it must first be acknowledged that Aboriginal groups operate under differing governance structures, from the Indian Act to Comprehensive Land Claim Agreements, with various components in between. Thus, there needs to be recognition that capacity is a subsection focusing on governance. Furthermore, the contemporary view of capacity-building goes beyond the conventional perception of training. The central concerns of building Aboriginal capacity - to manage change, to resolve conflict, manage institutional pluralism, to enhance coordination, etc., require a broad and holistic view of capacity development. ${ }^{379}$

Frideres argues that the Canadian government (and society) created a "culture of poverty" by replacing Aboriginal peoples' traditional mode of production with one that required specific skills and knowledge in which Aboriginal peoples were denied training, education and entry in the labour market. ${ }^{380}$ However, Widdowson notes that "scholars studying Aboriginal issues are hopeful that with the settlement of land claims and implementation of self-government agreements, Aboriginal dependency can be overcome". ${ }^{381}$

In 1998, after the Delgamuukw ruling, a Post-Delgamuukw Capacity Panel was established to "examine opportunities for enhancing British Columbia First Nations' capacity to manage land and resource issues in a post-Delgamuukw world". ${ }^{382}$ The panel

\footnotetext{
379 NRM, "Capacity Building" online: $\mathrm{nrm}<$ http://nrm-changelinks.net/capacity.html, > (date accessed: 3 October 2005).

${ }_{380} \quad J$. Frideres, supra note 33 at 8 and 66.

381 F. Widdowson, Separate but Unequal: The Political Economy of Aboriginal Dependency, Presentation for the Annual Conference of the Canadian Political Science Association, June 1, 2003. 382 Indian and Northern Affairs Canada, "Post-Delgamuukw Capacity Panel Report" (1999) online: Indian and Northern Affairs Canada $\mathrm{http} / / / \mathrm{www}$.ainc-inac.gc.ca/ps/ecd/env/pos e.html (last accessed: 30 August 2005).
} 
adopted a liberal definition of capacity building and referenced it as "the ability of the community and its members to perform (land and resource and economic development) functions effectively, efficiently and sustainably" ${ }^{383}$ Lack of capacity thereby included lack of: knowledge, expertise and skill in land and resource management; data and information; and negotiation skills. ${ }^{384}$

The Delgamuukw Capacity Panel further noted:

Capacity building which is consistent and continuous is essential for the success of First Nations. A holistic approach to capacity building which incorporates the Nation's strategic plan is required; capacity building in regards to land and resource management is just one element. Some aspects of capacity building may not be achieved in the short term but may require a long term, coordinated commitment from all parties. Such a commitment must include the provision of the resources required for enhanced training and education as well as innovative and 'no cost' solutions to the challenges facing First Nations. This commitment must also include the modification of government programs so that they support First Nations' capacity building efforts. ${ }^{385}$

Since the release of the Capacity Building Report, INAC has acknowledged that many Aboriginal groups lacked the necessary capacity to negotiate and address resource and management issues which greatly impacted on their ability to participate in negotiation and carry out land and resource development projects. ${ }^{386}$ To address this issue, the Negotiation Preparedness Initiative (NPI) was introduced. The NPI was designed to "enhance the capacity and expertise of Aboriginal groups that have asserted a land claim to prepare for negotiations on land resource components of comprehensive claims settlements". ${ }^{387}$

\section{First Floor - The Treaty}

As the first floor is erected upon the co-operative relationship foundation,

\begin{tabular}{ll}
\hline 383 & Ibid. at 4. \\
384 & Indian and Northern Affairs Canada, "Evaluation of the Negotiation Preparedness Initiative", \\
$(2003)$ & [unpublished, archived at the Library of Indian and Northern Affairs Canada] at p 7. \\
385 & Ibid. at 14. \\
386 & Ibid. at p i. \\
$\begin{array}{ll}387 & \text { Ibid. at p i. }\end{array}$
\end{tabular}


negotiations including accommodation, balance, consultation, continued capacity building and recognition, and settlement of the treaty can take place. The treaty serves as a tool to fulfill the objectives of the communities. These include, but are not limited to, economic development opportunities in a stable yet diverse and flexible environment, the strengthening of culture and linguistic identity, and building healthy communities.

The reconciliation model of certainty recognizes that 'incremental treaties ${ }^{388}$ are just another form of reconciling differences, restoring friendships and building capacity and relationships. ${ }^{389}$ Incremental treaties can play just as important a role as their counterparts, comprehensive treaties, since the certainty sought will reconcile immediate differences and allow for continued relationship building to take place, although the end result may never be a full-fledged treaty. The use of incremental treaties could be expanded and extended to non-land issues. For example, incremental treaties could be used to address social concerns such as an over-representation of Aboriginal people in the judicial system, youth suicide and lack of adequate housing, which respondents in the interviews noted as being barriers to the achievement of certainty. By reconciling social inequalities and strengthening community capacity, Aboriginal groups will be in a better position to negotiate land claim settlements.

As Hamilton recommended, the treaty should contain mutual assurances between Aboriginal groups and the federal and provincial/territorial governments, since without these the treaty will not work. ${ }^{390}$ (Please Appendix 6) Under the mutual assurance clauses "the parties agree to whatever it [the treaty] contains; each party agrees to do certain things and to refrain from doing other things; each wishes to give assurances to the parties of their commitment to the agreements they have negotiated". ${ }^{391}$ While I will not suggest

\footnotetext{
388 See definition given in footnote 280.

389 These documents would not be constitutionally protected like modern-day treaties as they are not vetted through parliament.

390 Stevenson, supra note 13 at 2.

$391 \quad$ Hamilton Report, supra note 5 at 106.
} 
alternative wording, in his report Hamilton listed some of the mutual assurances suggested by Aboriginal people and I favour the following as it captures the intent of the model being proposed:

The parties enter into this treaty in a spirit of mutual respect and recognition. It is their wish to establish a relationship of trust which will enable them to work in cooperation with one another. ${ }^{392}$

Under the reconciliation model, rights do not have to be exhaustively set out, although an Aboriginal group may adopt this approach like the Nisga'a Nation did; for most, a more appropriate mechanism might be the assurance clause: "assurance that the parties will only exercise rights respecting the ownership of or use of lands or resources in accordance with the terms of the treaty ${ }^{1393}$ or a non-assertion clause like that used in the Tlicho Agreement, which reads: [The Aboriginal beneficiary] will not exercise or assert any Aboriginal or treaty rights, other than any rights set out in the Agreement. ${ }^{394}$ These clauses are also referred to as good faith clauses.

However, unlike the Tlicho Agreement, the reconciliation model of certainty would exclude a back up release that calls for the ceding and surrendering of rights if an assertion of rights outside the treaty were made. Instead, dispute resolution techniques would be built into the agreement which clearly lays out how to deal with an assertion/ breach in the treaty. More so, dispute resolution should be used to address/reconcile

$392 \quad$ Ibid. at 107. Other example given were:

"The agreement will be final and binding on all parties concerned and their terms and conditions [will] always [remain] in force;

Aboriginal people would always maintain their Aboriginal title which would be subject to the terms and conditions of the land claim agreement;

The parties agree to be bound by the Treaty, to respect it, and to abide by its terms and conditions;

The Crown undertakes that it will not exercise any rights or authority it may have other than in accordance with the terms of the treaty;

The First Nation undertakes that it will not exercise any rights or authority it may have other than in accordance with the terms of the treaty;

The First Nation also agrees to that it will not exercise any other Aboriginal right in a manner that would conflict with any provision in the treaty;

The parties agree to accept and respect the interest of others that are referred to in the treaty; and

This treaty satisfies all foreseeable claims which the parties have with respect to the lands and resources covered by the Treaty Area."

393 Ibid. at 108 .

$394 \quad$ Tlicho Agreement supra note 303 at s.2.6.1. Presented in a modified format. 
differing interpretations that may arise from the treaty. Resolution mechanisms could include: arbitration, mediation, judicial review or the establishment of a resolution board to deal with such matters, although it would be important for the treaty to detail what disputes should be addressed and what mechanisms the parties would want to use to address them.

It is important to note that Hamilton observed in his report that while some treaties have dispute mechanisms built into the treaty, they are often restrictive and do not include arbitration powers to interpret any provision of the treaty. ${ }^{395}$

\section{Second Floor-Treaty Implementation}

Another important reoccurring theme that surfaced from the interviews with respondents focused on the implementation of the agreements. Effective 1986, implementation plans are negotiated simultaneously and annexed to the final agreement, however, they are not afforded constitutional protection like the final agreement. Once a final agreement is initialed, the early stage of the implementation process begins. Many respondents expressed the need for the obligations in the agreements to be implemented to avoid the mistakes made in the past with the historical treaties.

The Land Claim Agreement Coalition argues that "the ink is barely dry on each land claims agreement before the federal government, especially its officials, abandons any talk of those objectives, and proceeds instead on the basis that the government's sole responsibility is to fulfil the narrow legal obligations set out in the agreement..."396

To address this concern, implementation plans should serve as a tool to determine what activities must be completed, by whom, by when, and address any problems that

\footnotetext{
$395 \quad$ Hamilton Report, supra note 5 at 113

396 The Land Claim Agreement Coalition is made up of the Council of Yukon First Nations, grand Council of the Crees, the Gwich'in Tribal Council, Inuvialuit Regional Corporation, Makivik Corporation, Nisga'a Lisims Government, Nunavut Tunngavik Incorporated and Sahtu Secretariat Incorporated. Land Claim Agreement Coalition, supra note 353 at 7.
} 
may arise in the interpretation of activities/obligations between the parties.

As the capacity of the Aboriginal community continues to build and co-operative relationships begin to flourish, Aboriginal communities will have the necessary tools to negotiate and conclude arrangements with other Aboriginal groups or third parties on how they will co-operate on managing lands and resources. This leads to opportunities to fully participate and provide input on land management and watershed management plans and boards; environmental assessment processes; and parks and wilderness management. The benefits derived from co-operative management arrangements are that they include representatives of both Aboriginal and non-Aboriginal Canadians; and they set out how the Aboriginal and non-Aboriginal management regimes will be harmonized.

The notion of a stable and predictable environment in which economic investment can take place was very important to the majority of those interviewed. Economic development, such as capital business projects, brings about self-sufficiency and jobs to a community, while at the same time building partnership opportunities. Jobs bring a better quality of life and hope for the future. However it is important to note that this does not happen overnight.

\section{Roof - Monitoring the Progress}

As the roof is placed on top of the building, certainty is achieved. Rights and title are reconciled throughout the structure and are protected under s. 35 of the Constitution. The finishing work can now begin to take place. However, it is recognized in house building that no matter how good the work-craft is, a house requires continuous maintenance; over the years items such as the roof and floors need to be repaired, replaced or updated.. I would argue that for many people, their house a reflection of themselves. They spend much time and money manicuring their lawns, painting walls, 
and even picking out the perfect accessories in order for their home to be warm and welcoming for themselves and those who visit. Yet the house could look beautiful on the outside, but, if one were to look beyond the façade, at the foundation and beams, they might be seen to be rotting and deteriorating. Parallels can be drawn between this image and Canada's relationship with Aboriginal peoples. For example, Canada held the first place spot on the United Nations' annual Human Development Report until 2001, when it was ranked third and as recently as 2003, Canada slipped to eighth place, all the while Aboriginal people living in Canada ranked $16^{\text {th }}$ or below. Canada's international reputation has always been a source of pride, yet over the years its image has been damaged by its treatment of Aboriginal people. ${ }^{397}$

To prevent the deterioration of the relationship, the treaty obligations must be fulfilled, reconciling interpretation differences, with the opportunity to negotiate rights that are not contained in the treaty or amend rights to ensure that they remain in keeping with legal decisions or societal changes. As with dispute mechanisms, amendment clauses have been added into numerous agreements, however, they have usually been restricted to particular clauses.

The final area that must be considered is the measurability of the process or success of the treaty. As per the OAG's 1998 recommendation, treaties should have a specific clause that allows for periodic impact assessments to be conducted. This would assist in identifying the positive or unintentionally negative aspects of the process and allow for adjustments to be made accordingly.

\footnotetext{
$397 \quad$ United Nations Development Programme, "Human Development Report 2004: Cultural Liberty in Today's Diverse World" (2004) online: Human Development Report < http://hdr.undp.org/hd/> (date accessed: 19 January 2005).
} 


\section{Summary}

The reconciliation model of certainty presented in this chapter shows that an alternative model of certainty can be achieved that recognizes the interests of all parties in settling land or treaty claims, without Aboriginal groups having to cede, release, surrender, extinguish or modify any rights that exist outside the treaty.

If certainty is to be achieved through the process of reconciliation, which is aimed at restoring to friendship the relationship between the Crown and Aboriginal people through the settlement of differences, then certain structures must be in place first. These include: a recognition of Aboriginal rights and title; Aboriginal participation in policy development and reviews; capacity building and consultation, and accommodation and balanced commitments.

Customized treaties are meant to serve as useful tools to fulfil Aboriginal objectives, forge partnerships, and allow for economic development opportunities in a flexible and diverse environment; although the economic benefits may not be immediate. The finality that is sought by the government with respect to settlement of title and resources is addressed by mutual assurances, respect and trust. 


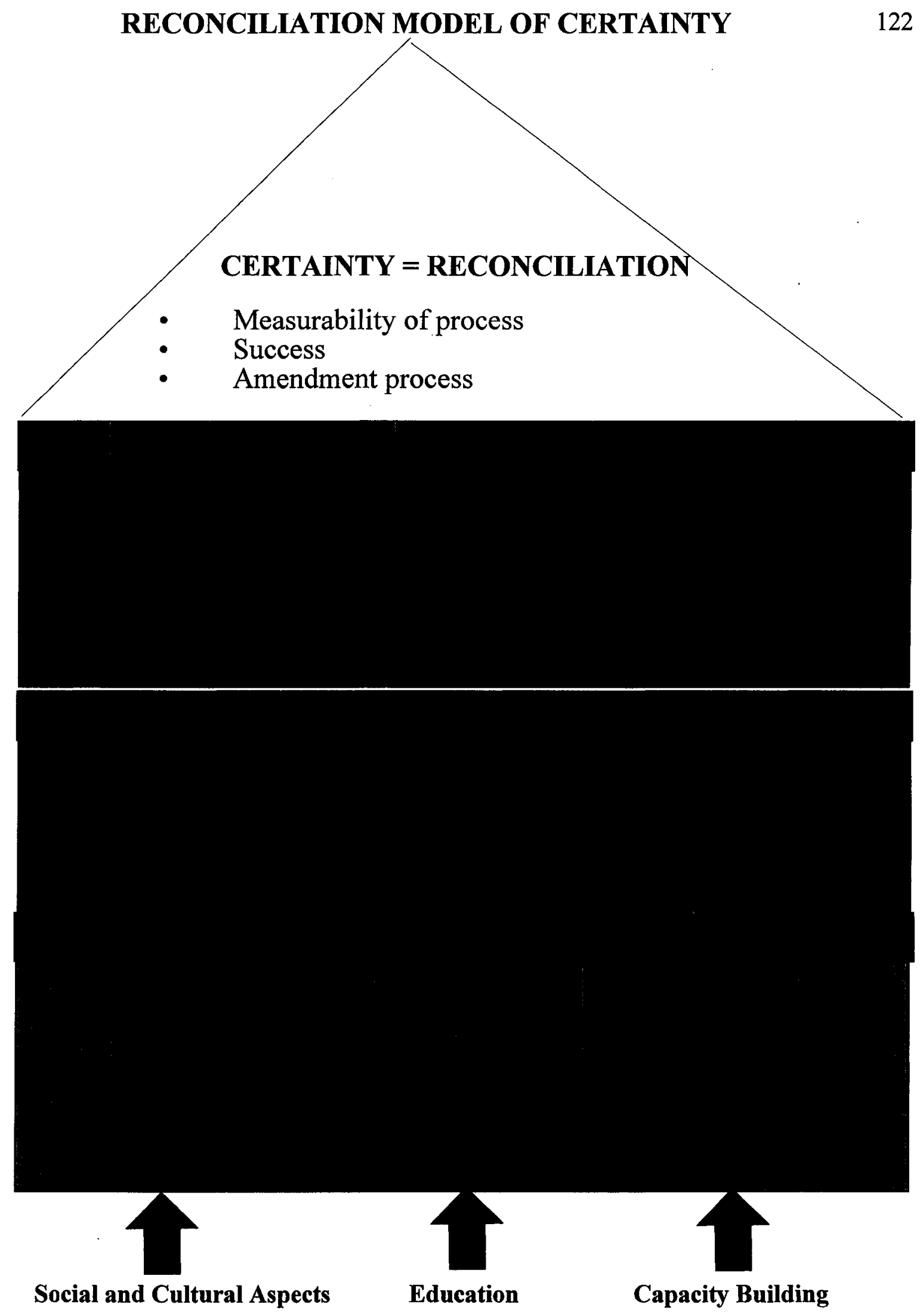

*Denotes subjective placement and these objectives may shift in the model depending upon the nature and scope of the treaty 


\section{CHAPTER 7}

\section{Conclusion}

This thesis was undertaken with the objective of establishing an alternative method of certainty in relation to settling land or treaty claims that recognizes the interests of all parties, without Aboriginal groups having to cede, release, surrender, extinguish or modify any rights that exist outside the treaty. In order to assess the validity of this task, a series of subsidiary questions were developed to ascertain what methods have been used in the past to achieve certainty; the extent that conflicting ideologies between Aboriginal organizations/groups and governments have affected the development of a new model; what, if any, direction have the courts given regarding Aboriginal treaty rights and title; and what commonalties or differences existed between the parties in creating a new model.

At the outset of this thesis, I loosely adopted Hamilton's assertion that certainty is achieved by assuring that issues affecting everyone involved have been dealt with to everyone's satisfaction. However, he and I departed on the definition of "everyone". While Hamilton opted for an inclusive model, given the nature and complexity of land claim agreements, I chose to restrict the definition to Aboriginal beneficiaries, the federal, provincial and territorial governments, with consideration and accommodation being given to third party rights when and where necessary.

The literature and document reviews showed that throughout the history of Canada, the notion of land ownership and rights has been fundamental in shaping the relationship between the nation state and its Aboriginal citizens. From the early period of contact, European settlers attempted to create a notion of certainty for both themselves and Aboriginal peoples by defining boundaries and reserve lands. Through the enactment of legislation such as the Royal Proclamation Act and the Indian Act, certainty developed 
into a cession, surrender and extinguishment model to allow Canada to grow as a nation by securing valuable lands.

Early treaties, such as the 'peace and friendship' and numbered treaties, played a beneficial role in providing the template for the treaty making process, as well as attempting to create certainty. Unfortunately, certainty could not be readily achieved, largely due to the conflicting ideologies that hindered the treaty-making process. For Aboriginal groups, it was a system based on the notion of a "permanent living relationship", that was meant to be viewed as a firm commitment to establish and maintain a mutual ongoing commitment to ensure treaty promises were fulfilled, in which Aboriginal rights would be protected, and the land would be mutually governed. For the Crown, it was a structure that sought finality in the way of cession, surrender and extinguishment to achieve certainty.

A study of court cases revealed that over the years, the Canadian legal system has played a key role in shaping and defining Aboriginal rights and title. Although the recent shift in the Courts' attitude has recognized the existence of Aboriginal rights based on traditional usage of land and resources, the process has been long, expensive, strenuous, and less than perfect, not to mention largely unresolved. Through their earlier decisions such as St. Catherine's Milling and Lumber and Calder on through to their more recent decisions in Delgamuukw, Marshall, and Powley, Canada's highest court has transformed the notion of Aboriginal rights and title.

In recent years, Aboriginal groups have sought redress in the courts as an alternative method of 'standing off' against the federal government, with mixed results. Litigation as a method of resolving disputes between the differing parties in the negotiation process has often been the source of, or served as, the driving force behind the development of key federal policies, as well as clarifying and achieving a limited 
recognition of Aboriginal rights and title. However, it has done nothing to solidify relationships between the parties.

Without a doubt, court decisions have been pivotal in achieving a quasi definition of Aboriginal rights; yet the differing views on the scope and nature of Aboriginal title and rights, the establishment of the comprehensive land claims negotiation criteria, use of extinguishment, surrender and ceding provisions have all lead to uncertainty and conflict in trying to resolve land claims.

Chapter 4 focused on the five separate task forces, committees, and commissions that were established to review the treaty-making process in various fashions and make recommendations to improve the process where deemed necessary. Since the publication of the reports, costing millions of dollars, only segments of the recommendations have been implemented. Throughout the reports, Aboriginal groups explicitly expressed that they were no longer willing to "cede, release or surrender" any more rights in order to achieve certainty in land claim settlements. While all the parties agree that certainty is important and even necessary, challenges lie in reconciling divergent views on the meaning and intent of achieving certainty in a contemporary context. Despite the ambiguity, these reports, and the subsequent responses to them by governments and Aboriginal groups, have been instrumental in highlighting not only the differences (i.e., recognition and accommodation) but also the common ground (i.e., need for economic interest, diversity and flexibility, co-operative relationship and the needs/interests of third parties) of the parties to the negotiation process and in their attempts to achieve certainty.

In exploration of the research questions, seven interviews were also conducted that lead to the identification of five additional themes, aside from the ones identified by the task forces and commissions. The first theme centred around the need for a simplified process to negotiate and settle modern-day treaties. Some respondents expressed concerns that final agreements have become too complex, legalistic and lengthy. The 
majority of the respondents also noted that there was a need to examine the concept of certainty. This included: what is meant by certainty, what is certainty meant to achieve, and how long should certainty be achieved for - finality versus ongoing relationships. These questions were taken into consideration in developing a new model of certainty.

The second theme, evolution and flexibility, noted that an essential element to the achievement of certainty was the need for growth and flexibility in the negotiation and settlement of treaties as well as in related policies. This was linked to findings of the commissions and task forces, which noted the need for diversity and flexibility, since a cookie cutter approach to negotiating and implementing final agreements fails to acknowledge the complexity and uniqueness of each community.

The third theme, stability, predictability and economic investment, highlighted the desire of Aboriginal communities and third parties to have opportunities to participate within the settlement area. The majority also noted that clarity and predictability of ownership and title were necessary components to ensuring that economic development could take place in the Aboriginal community.

The fourth theme focused on the implementation of the agreements. Through the literature and document reviews and interviews, the need was clearly expressed to implement the treaty obligations to avoid repeating the mistakes made with the historic treaties. Lastly, the fifth theme, healthy communities, questioned the achievement of certainty in communities that lacked community stability at the social level.

To date, twenty-one comprehensive land claims have been settled using the various methods of certainty outlined throughout this paper, with approximately $70+$ negotiation tables underway across Canada. Under the provisions of the first modern-day treaty, the $J B N Q A$ and subsequent agreements, blanket extinguishment was required in order for the government to deem that certainty had been achieved. Agreements negotiated since 1982 no longer require that blanket extinguishment take place, instead, 
certainty provisions were based on cede, release and surrender or a modified rights approach. In 2004, a new model of certainty, the non-assertion technique, was adopted in the Tlicho Final Agreement, and comes the closest to matching Hamilton's model.

While the research indicates that the achievement of certainty was a very important component in the settlement of land claims, an adequate model to address the diverse needs of Aboriginal communities is lacking. Certainty, as it is currently defined in final agreements, has been highly criticized for being too legalistic and for hindering the negotiating process. This is evident in the fact that none of the models produced to date have been endorsed by all Aboriginal groups.

Taking into consideration the views expressed in the literature, document and task force/commission papers, coupled with the majority opinions expressed by the interviewees, I formulated a new model - The Reconciliation Model of Certainty - with Hamilton's model serving as a base.

The Reconciliation Model of Certainty is premised on flexibility and is grounded in the notion that certain structures must first be firmly established to form the foundation on which certainty is achieved; with which other elements interface throughout the model. Certainty as a reconciliation model is defined as the process which restores to friendship the relationship between the Crown and Aboriginal people through the settlement of differences as opposed to requiring Aboriginal people to sever their connection to land and rights. As such, the model is designed to encourage Aoriginal people and the Crown to negotiate agreements that encompass the settlement of land, resources and social issues; supported by recognizing of Aboriginal rights and title. As such, the reconciliation model supports common goals vs opposing goals. Mutual respect and trust serve as support beams and must be evident throughout the process if the relationship is to stand up over time.

The use of incremental treaties may be considered as another mechanism which is 
aimed at achieving certainty, although it may be for a shorter period of time than a modern-day treaty. Furthermore, incremental treaties could be used to address social concerns such as the unemployment rate, educational attainment, over-representation of Aboriginal people in the judicial system, poor health, premature death, chronic disease, youth suicide and lack of adequate housing, which respondents in the interviews noted as being a barrier to the achievement of certainty.

As a consequence of the negotiating and settling of treaties, a series of obligations arise. Fulfilment of these obligations, (on an ongoing basis) anchored to a strong foundation, is important in developing economic and partnership opportunities to build strong and stable communities. For Aboriginal groups, treaties can serve as a tool to achieve community objectives and further strengthen their distinct status in Canadian society.

Mutual assurances form a commitment between parties to work together to build co-operative relationships, resolve disputes that may arise from the joint commitments made in the treaties, including treaty interpretation, and allow for evolution through the use of amendment processes.

In conclusion, I have attempted to demonstrate that an alternative model of certainty can be developed that moves beyond a mere change in terminology and recognizes that certainty is the final product of a process and not just a clause in an agreement. Through the use of period reviews or evaluations, all parties can build on lessons learned, continue to reinforce positive impacts and/or address unintended negative impacts. This allows for diversity and flexibility and supports the notion that the process of achieving certainty must be done through the reconciling of differences. Without this reconciliation, certainty will always be a point of conflict for all parties. 


\section{LEGISLATION}

An Act to amend and consolidate the laws respecting Indians, 1876, c.28

An Act to prevent trespasses to Public and Indian Lands, C.S.U.C., 1859, c.81.

An Act respecting Fisheries, R.S.C. 1970, c. F-14, ss.34, 61(1).

An Act respecting Indians, R.S.C. 1985, c.1-5

An Act respecting the Management of the Indian Lands and Property, S.C. 1860. C.151.

Constitution Act, 1867 (UK), 30 \& 31 Vict., c. 3, reprinted in R.S.C. 1985, App. II, No.5. Constitution Act 1982 (UK), 1982, c.11, s. 35.

James Bay and Northern Québec Native Claims Settlement Act, S.C., 1976-77, c.32

Nisga'a Final Agreement Act, S.C., 2000, c.7

Royal Proclamation Act of 1763, R.S.C., 1985, App. II, No.1

Western Arctic (Inuvialuit) Claims Settlement Act, S.C, 1984, c. 24

Yukon First Nations Land Claims Settlement Act, S.C., 1994, c. 34

Bill C-14, An Act to give effect to a land claims and self-government agreement among the Tlicho, the Government of the Northwest Territories and the Government of Canada, to make related amendments to the Mackenzie Valley Resource Management Act and to make consequential amendments to other Acts, 1st Sess., 38 ${ }^{\text {th }}$ Parl., 2004 ( $3^{\text {rd }}$ reading 7 December 2004).

\section{JURISPRUDENCE}

Calder v. Attorney General of British Columbia [1973] 3 S.C.R. 313.

Campbell v. the Attorney General of British Columbia (2002) BCSC 1123

Delgamuukw v. The Queen in Right of British Columbia, [1997] 3 S.C.R. 1010.

Guerin v. R. [1984] 2 S.C.R. 335

Haida v. British Columbia [2004] SCC 73.

Hamlet of Baker Lake v. Minister of Indian Affairs and Northern Development, (1979), 107 D.L.R. (3d) 513 (F.C.T.D).

Johnson and Graham's Lessee v. William M'Intosh, 21 U.S. (8 Wheaton) 543 (1823)

R. v. Powley [2003], 2 S.C.R. 207

$R$. v. Marshall [1999] 3 S.C.R. 533.

$R$. v. Sparrow [1990] 4 W.W.R. 410 (1) S.C.R. 1075, 28(1-10).

$R$. v. Van der Peet, [1996] 2 S.C.R.

Re Paulette et al. and the Registrar of Land Titles (1975), 63 D.L.R. (3d) 1 (also reported: [1976] 2 W.W.R. 193).

Simon v. The Queen, [1985] 2 S.C.R. 387.

St. Catherines Milling \& Lumber Co. v. The Queen (1888), 14 App. Cas. 46 (JCPC).

Taku River Tlingit First Nation v. British Columbia [2004] SCC 74

Wik Peoples v. Queensland (1996), 187 C.L.R. 1 


\section{SECONDARY MATERIALS}

Aboriginal Justice Implementation Commission, "Final Report: Recognition and Reconciliation" (2001), online: AJIC <http://www.ajic.mb.ca/reports/final cho2.html> (date accessed: 4 October 2005).

Aboriginal Oral Traditions, (2003) online: Frog and Toad $<$ http://www.frogandtoad.com.au/aboriginies/language4.html > (last modified: 2 December 2003).

Asch M. and Zlotkin N., "Affirming Aboriginal Title: A New Basis for Comprehensive Claims 193 Negotiation" in Aboriginal and Treaty Rights in Canada: Essays on Law, Equality and Respect for Differences, edited by M. Asch (Vancouver: UBC Press, 1997) at 208.

Assembly of First Nations, "Assembly of First Nations' Critique of Federal Land Claims Policies" (1990), online: ubcic at p 1 <http://www.ibcic.bc.ca/afn.htm> (last modified: 2 April 2000).

Assembly of First Nations, "Doublespeak of the 90's: A Comparison of Federal Government and First Nation Perception of Land Claims Process" (1990) online: ubcic $<$ http://www.ubcic.bc.ca/doubletalk.htm $>$ (last modified: unknown).

Assembly of First Nations, (1995) "Extinguishing Extinguishment: Bringing an Era to an End", A Declaration Presented to the Hon. Alvin J Hamilton [unpublished, archived at the Library of Indian and Northern Affairs].

Assembly of First Nations, Material on Canada's Comprehensive Claims Policy, [unpublished, archived at the Library of Indian and Northern Affairs].

Australian Indigenous Law Reporter, "Canadian Royal Commission on Aboriginal Peoples: Interim Reports" (1996) online: AustLII $<$ http://www.austlii.edu.au/au/journals.OLD/AILR/1996/8.html > (date accessed 7 February 2004).

Badcock W., Who Owns Canada?: Aboriginal Title and Canadian Courts, (Ottawa: Canadian Association in Support of Native Peoples, 1976).

Barrell G., Young R., and Price R., Indian Treaties and the Law: An Interpretation for Laymen, (Alberta: Indian Association of Alberta, 1975).

Berger T., "Foreword" in Berger T, ed., Nisga'a: People of the Nass River (Vancouver: Douglas and McIntyre Ltd., 1993). 
Bodley J, Victims of Progress, 3 ed. (California: Mayfield Publishing, 1990).

Boldt M., and Long J.A., "Tribal Philosophies and the Canadian Charter of Rights and Freedoms", in M.J. Mac Neil, N. Sargent, and T.A. Dawson, Introduction To Private Law Relationships, $2^{\text {nd }}$ Ed., (North York: Captus Press Inc., 1995) at 149.

Borrows J., "Practical Reconciliation, Practical Re-Colonisation?" (2004) 2 Land, Rights, Laws: Issues of Native Title 1.

British Columbia, Two Perspectives on Certainty, BC Treaty Commission, Venture into a Treaty World, by Jerry Lampert, (British Columbia, March 2004).

Brock K.L., "One Step Forward...Accommodating Aboriginal Rights in Canada" (Annual Meeting of the American Political Science Association, Washington, 31 August - 3 September 2000) [unpublished].

Canada, Aboriginal Self-Government: The Government of Canada's Approach to Implementation of the Inherent Right and the Negotiation of Aboriginal Self-Government (Ottawa: Minister of Public Works and Government Service Canada, 1995).

Canada, Indian Treaties and Surrenders From 1680 To 1890, vol.1 (Ottawa: Fifth House Publishers, 1992).

Canada, Joint Committee of the Senate and the House of Commons on Indian Affairs, (Ottawa: Queen's Printer and Controller of Stationary, 1961) (Co-chairs: Honourable Senator James Gladstone and Mr. Lucien Grenier, M.P.).

Canada, Parliamentary Task Force on Indian Self-Government, Indian Self-Government in Canada, (Ottawa: Department of Indian Affairs and Northern Development, 1983).

Canada, Questioning Canada's Title to Land: The Rule of Law, Aboriginal Peoples and Colonialism, Law Commission of Canada, Speaking Truth to Power: A Treaty Forum by J. Borrows, (Ottawa: Minister of Public Works Canada, 2001) at 35-72.

Canada, Royal Commission on Aboriginal Peoples, Extinguishment of Rights of Aboriginal Peoples: Problems and Alternatives, (Ottawa: Supply and Services, 1995).

Canada, Report of the Royal Commission on Aboriginal People, Looking Forward, Looking Back, Vol.1, (1996) online: Indian and Northern Affairs Canada $<$ http://www.ainc-inac.gc.ca/ch/rcap/sg/sgmm_e.html $>$ (last modified: 24 December 2003).

Canada, Royal Commission of Aboriginal Peoples, Reclaiming Our Nationhood, Strengthening Our Heritage, (Ottawa: Supply and Services, 1993). 
Canada, Royal Commission on Aboriginal Peoples, Vol. 2, Restructuring the Relationship, (1996) online: Indian and Northern Affairs Canada $<$ http://www.aincinac.gc.ca/ch/rcap/sg/sgmm e.html $>$ (last modified: 24 December 2003).

Canada, Royal Commission on Aboriginal Peoples, Treaty Making in the Spirit of Co-existence: An Alternative to Extinguishment (Ottawa: Supply and Services, 1995).

Canada, Task Force to Review Comprehensive Claims Policy, Living Treaties: Lasting Agreements, Report of the Task Force to review the Comprehensive Policy, (Ottawa: Department of Indian Affairs and Northern Development, 1985).

Canada, Visions of Certainty: Challenging Assumptions, Law Commission of Canada, Speaking Truth to Power: A Treaty Forum by M. Stevenson (Ottawa: Minister of Public Works Canada, 2001) at 113-134.

Canadian Race Relations Foundation, "Aboriginal Rights are Human Rights", (2000) online: CRR $<$ http://www.crr.ca/EN/WhatsNewEvents/Events/WCAR/eWhaNew EventsAboriginal.ht m> (date accessed: 19 January 2005).

Cassidy F., "Aboriginal Land Claims in British Columbia" in K. Coates, ed., Aboriginal Land Claims in Canada: A Regional Perspective (Toronto: Copp Clark Pitman Ltd., 1992) at 11.

CBC.CA, "Deal lets Ontario Métis hunt, fish freely", CBC.CA (8 July 2004) online: $<$ http://www.cbc.ca/stories/2004/07/08/canada/Metis hunting040708> (last modified: 8 July 2004).

Centre of Research and Information on Canada, "New Findings on Canadians' Attitudes to Improving Aboriginal Quality of Life, New Release (11 November 2004).

Continuing Legal Education, "The Inherent Right of Self-Government as an Aboriginal and Treaty Right", (Background Paper) by D. Opekokew, Toronto 1994 vol.2 at 12.

Colvin E., Legal Process and the Resolution of Indian Claims, (Saskatchewan: Native Law Centre, 1981).

Culhane D., The Pleasure of the Crown: Anthropology, Law and First Nations, (Burnaby: Talonbooks, 1998).

Daniel R., A History of Native Claims Processes in Canada, 1867-1979, (Ottawa:

Minister of Indian Affairs and Northern Development, 1983). 
Department of Indian Affairs and Northern Development, Canadian Bar Association "Negotiation or Litigation - Which Way Forward?" (Manitoba: 2000).

Department of Indian Affairs and Northern Development, "Comprehensive Claims Critique and Analysis" (1987) [unpublished: archived at the Library of Indian and Northern Affairs] at II.

Department of Indian and Northern Development (1987) Comprehensive Land Claims Policy, Minister of Supply and Services Canada, Ottawa.

Department of Indian Affairs and Northern Development (1993) Federal Policy for the Settlement of Native Claims, Minister of Indian Affairs and Northern Development, Ottawa.

Department of Indian Affairs and Northern Development (1981) In All Fairness: A Native Claims Policy, Minister of Supply and Service Canada, Ottawa.

Department of Indian Affairs and Northern Development (1999) Individuals Responsible for Aboriginal and Northern Affairs in Canada 1755 to 1999, online: INAC $<$ http://www.inac.gc.ca/pr/info/info38 e.html $>$ (last modified: 29 May 2000).

Department of Indian and Northern Affairs Development, (1997) Gathering Strength: Canada's Aboriginal Action Plan, Minister of Indian Affairs and Northern Development, Ottawa.

Diamond B., "Aboriginal Rights: The James Bay Experience", in J.A. Long et al., Aboriginal Rights: Toward An Understanding (Alberta: University of Lethbridge, 1998).

Diamond B., Highlights of the Negotiations Leading to The James Bay and Northern Québec Agreement, [unpublished, archived at the Library of Indian and Northern Affairs].

Dickason O.P., Canada's First Nations: A History of Founding Peoples from Earliest Times, (Toronto: The Canadian Publisher, 1992).

Duhaime's Law Dictionary, online: Duhaime's Law Dictionary, online:

$<$ http://www.duhaime.org/dictionary/dict-gh.htm\#H $>$ (date accessed: 03 September 2004) s.v. fee simple.

Elliot D., Law and Aboriginal Peoples in Canada, $3^{\text {rd }}$., (North York: Captus Press Inc., 1997)

Elliot D., "The Legal Status of Aboriginal and Treaty Rights in Section 35(1) of the Constitution Act, 1982" Canadian Bar Association (date unknown). 
Elliot D., and Warskett R., Introduction To Public Law, $4^{\text {th }}$ Ed., (North York: Captus Press Inc., 1999) at 258.

First Nations Summit, "First Nations Summit Statement to The Honourable Jane Stewart, Minister of Indian Affairs, Government of Canada and the Honourable John Cashore, Minister of Aboriginal Affairs, Province of British Columbia on the Supreme Court of Canada Decision in Delgamuukw" (31 January 1998).

Flanagan T., First nations? Second Thoughts, (Montreal: McGill University Press, 2000).

Frideres J., Native Peoples in Canada: Contemporary Conflict, $4^{\text {th }}$ ed. (Scarborough: Prentice-Hall, 1993).

Funston B., and MeehanE., Canada's Constitutional Law in a Nutshell, (Toronto: Carswell, 1994).

Gosnell J., Nisga'a Tribal Council, Understanding the Nisga'a Treaty, (1998) online: kermode.net $<\underline{\text { http:} / / w w w . k e r m o d e . n e t / n i s g a a / t r e a t y / p r e f a c e . h t m>~}>$ (last modified: September 1998).

Guswhenta (Kaswehntha) - Two Row Wampum Belt, online: hometown AOL $<$ http://hometown.aol.com/miketben/miketben.htm> (last modified: unknown).

Harring S., White Man's Law: Native People in Nineteenth Century Canada Jurisprudence, (Toronto: University of Toronto Press, 1988).

Henderson B., "A brief Introduction to Aboriginal Law in Canada", online, $<$ http://www.bloorstreet.com/200block/brintro.html $>$ (last modified: 15 January 1996).

Hendrie S., The James Bay Agreement: 20 Years of Development, online: $<$ http://www.makivik.org/MakivikNews/MN20thAnn/English/eMN20-Overview.html > (last modified: 29 August 2000).

Horter W., "The Crown's Quest for 'Certainty", Dogwood Initiative (22 May 2004) online: Dogwood Initiative $<$ http://www.dogwoodinitiative.org/Pages/newsroom/bulletin.php?filepath?=http://www. do > (date accessed: 10 December 2004).

House of Commons, Minister Andy Scott's response to various questions in Question Period on November 1, 2004.

House of Commons, Standing Committee on Aboriginal Affairs and Northern Development (24 October 1995) 1107 (A.C. Hamilton). 
Hughes B., “Gustafsen Trial Concludes, Concern Doesn't", The Peak, vol 96, issue 5, June 2, 1997.

Indian and Northern Affairs Canada and Canadian Polar Commission 2000-2001 Main Estimates Part III - Report on Plans and Priorities (Ottawa: Public Works and Government Services, 2000).

Indian Affairs and Northern Development, Canada and Aboriginal Peoples: A New Partnership, by Hon. A.C. Hamilton (Ottawa: Minister of Indian Affairs and Northern Development, 1995).

Indian and Northern Affairs Canada, Comprehensive Claims Information Booklet, (2000) Online: Indian and Northern Affairs Canada

$<$ http://intra/inac/docs/aboutthedepartment/headquarterssectors/claims\&indian government> (last modified: 29 April 2000).

Indian Affairs and Northern Development, Comprehensive Claims Branch Introductory Web Page, online: <http://www.inac.gc.ca/ps/clm/ccb_e.html $>$ (last modified: 31 December 2000).

Indian and Northern Affairs Canada, Chronology of Events Leading to the Final Agreement with the Nisga'a Tribal Council, online: INAC

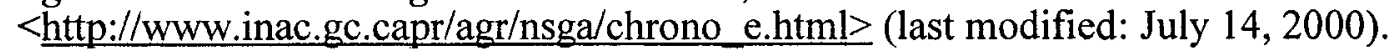

Indian and Northern Affairs Canada, "Evaluation of the Negotiation Preparedness Initiative" (2003) [unpublished, archived at the Library of Indian and Northern Affairs Canada].

Indian and Northern Affairs Canada, Federal Policy for the Settlement of Native Claims (1993), Minister of Indian Affairs and Northern Development, Ottawa, Canada.

Indian and Northern Affairs Canada, First Nations in Canada, (Ottawa: Minister of Public Works and Government Services Canada, 1997).

Indian and Northern Affairs Canada, News Release: "Historic Tlicho Land Claim and Self-Government Agreement Signed Today", (25 August 2003) online: INAC $<$ http://www.ainc-inac.gc.ca/nr/prs/m-a2003/2-02364_e.html > (last modified: 23 April 2004).

Indian and Northern Affairs Canada, Comprehensive Claims (Modern Treaties) in Canada (March 1996) online INAC < http://www.inac.gc.ca/pr/info/trty_e.html > (last modified: 23 April 2004).

Indian and Northern Affairs Canada, "Modern Management Practices and Assessments", online: INAC $<$ http://www.ainc-inac.gc.ca/pr/pub/fn/pdf/mmpa_e.pdf $>$ (last modified: 
18 February 2000).

Indian and Northern Affairs Canada, "Post-Delgamuukw Capacity Panel Report" (1999) online: Indian and Northern Affairs Canada $<\underline{h t p:} / /$ www.aincinac.gc.ca/ps/ecd/env/pos_e.html> (last accessed: 30 August 2005).

Indian and Northern Affairs Canada, Resolving Aboriginal Claims: A Practical Guide to Canadian Experiences, (Ottawa: Minister of Indian Affairs and Northern Development, 2003).

Komar R., The Royal Proclamation Act of 1763: A Legal Inquiry Into Indian Land In Canada (1971) [unpublished, archived at the Library of Indian and Northern Affairs].

Land Claim Agreement Coalition, "A New Land Claims Implementation Policy", online: itk $<$ http://www.itk.ca/media/supporting-docs/landclaim-discussionpaper.pdf $>$ (last modified: unknown).

Little Bear L., "A Concept of Native Title", in M.J. MacNeil, N. Sargent, and T.A. Dawson, Introduction To Private Law, 2nd Ed., (North York: Captus Press Inc., 1995) at 316.

Lochead K., "The Political Accommodation of Native Title in Canada and Australia: A Critical 168 Comparative Analysis of Canada's Comprehensive Claims Policy and Australia's Native Title Act", online: CPSA <http://www.cpsa-acsp.ca/papers2004/Lochead.pdf $>$ (last accessed: 21 January 2006) at 24.

Lordes A., The Master's Tools Will Never Dismantle The Master's House, in $\underline{\text { Sister }}$ Outsider, (Trumansburg: Crossing Press, 1984) 110-113.

MacNeil M., "Aboriginal Property and Ideology" in M.J. MacNeil, N. Sargent, and T.A. Dawson, Introduction To Private Law, 2nd Ed., (North York: Captus Press Inc., 1995) at 327.

McCallum A., "Dispute Resolution Mechanisms in the Resolution of Comprehensive Aboriginal Claims: Power Imbalance Between Aboriginal Claimants and Governments", (1995) online: E Law

$<$ http://www.murdoch.edu.au/elaw/indices/title/mccallum_abstract.html $>$ (last modified: 29 November 2001).

Magnet J., Constitutional Law of Canada, Vol.2, $3^{\text {rd }}$, ed., (Toronto: Carswell, 1987).

Mandell L., Creeping Out of the Dark Ages...Slowly, B.C. for Continuing Legal Education, Vancouver Conference, July 1993. 
Merriam-Webster's Dictionary, online: Merriam-Webster $<$ http://www.m-w.com/ $>$ (date accessed: 25 April 2005) s.v. reconcile.

Ministry of Aboriginal Affairs, Province of British Columbia, Social and Economic Impacts of Aboriginal Land Claim Settlements: A Case Study Analysis Final Report (December 1995) online: AAF <http://www.aaf.gov.bc.ca/aaf/pubs/arafr.htm> (date accessed: 19 February 2001) at 10.

Morse B., "Aboriginal Peoples and the Law" in B. Morse, ed., Aboriginal Peoples and the Law: Indian, Metis and Inuit Rights In Canada (Ottawa: Carleton University Press, 1991) at 1.

Native Law Centre, Constitutional Entrenchment, Legal Information Service, Report No.5 (Saskatchewan: University of Saskatchewan, 1980).

North.cbc.ca, "Last piece of Tli Cho agreement brought to legislature", CBC.CA (21 October 2004) online: north.cbc.ca

$<$ http://north.cbc.ca/regional/servlet/View?filename=tli-cho-legislature-10212004 $>$ (date accessed: 21 October 2004).

Northern Quebec Inuit Association, Summary of James Bay Agreement: November 11, 1975, As it affects the Inuit of Quebec, 1976 [unpublished, archived at the Library of Indian and Northern Affairs].

NRM, "Capacity Building" online: $\mathrm{nrm}<$ http://nrm-changelinks.net/capacity.html, $>$ (date accessed: 3 October 2005).

Office of the Auditor General, Report of the Auditor General of Canada to the House of Commons, (1998) online: OAG

$<$ http://www.oag-bvg.gc.ca/domino/reports.nsf/html/0112ce.html $>$ (last modified December 1998).

Office of the Auditor General, Report of the Auditor General of Canada to the House of Commons, (2001) online: OAG

$<$ http://www.oag-bvg.gc.ca/domino/reports.nsf/html/0112ce.html $>$ (last modified December 2001).

Office of the Prime Minister, New Release, "Speech from the Throne" (5 October 2004).

Opinion Canada, "Canadians want strong Aboriginal cultures but are divided on Aboriginal rights", (2003) Vol. 5 online: Opinion Canada <http://www.opinioncanada.ca/en/articles $>$ (date accessed: 17 January 2005).

Palys T.S., "Prospect for Aboriginal Justice in Canada", online:sfu 
$<$ http://www.sfu.ca/ palys/prospect.htm> (last modified: 19 November 1997).

Paul D., Indian Act, 1867.online: danielnpaul

$<$ http://www.danielnpaul.com/ia1876.html $>$ (last modified: unknown).

Plain F., "Aboriginal Rights: A Treatise on the Rights of the Aboriginal Peoples on the Continent of North America" in J.A. Long, M. Boldt, and L.L.Bear, Aboriginal Rights:

Toward An Understanding (Alberta: University of Lethbridge, 1983).

Position of the Grand Council of the Crees (Of Québec) and the James Bay Crees

Respecting the Possible Imposition of a 150, 000 Man/Day Limit on the Income Security

Program for Cree Hunters and Trappers Established by Section 30 of the James Bay

Northern Québec Agreement, December 1977 [unpublished, archived at the Library of

Indian and Northern Affairs].

Presentation to the Select Standing Committee on Aboriginal Affairs by the Fraser Valley Treaty Advisory Committee, Clint Hames the Mayor of Chilliwack and Chair of the Fraser Valley Treaty Advisory Committee (17 October 2001).

Prest G., "Overview of the Aboriginal Land Question in BC" (1997) online: ubc $<$ http://www.library.ubc.ca/ereserve/frst100/overview.htm> (date accessed: 14 April 2002).

Province of British Columbia, Social and Economic Impacts of Aboriginal Land Claim Settlements: A Case Study Analysis - Final Report (1995) online: gov. bc

$<$ http://www.aaf.gov.bc.ca/aaf/pubs/arafr.htm> (last modified: 1995).

Reaching Just Settlements: Land Claims in British Columbia, (Lantzville: Oolichan Books and The Institute for Research on Public Policy, 1991).

Reesor B., The Canadian Constitution in Historical Perspective, (Scaraborough: PrenticeHall, 1992).

Roberts B.,"Federal Government wants to start talks about treaty rights" Transcript from

Information Morning Radio Fredericton CBZ-Am (01 January 2001) Reference \#317310B-170808.

Rotman L., Parallel Paths: Fiduciary Doctrine and the Crown-Native Relationship in Canada (Toronto: University of Toronto Press Inc., 1996).

Rudnicki W., "Reveille for First Nations: The Politics of Aggression and Defence", (January 1987) [unpublished, archived at the Library of Indian and Northern Affairs]. 
Rynard P., "Welcome In, But Check Your Rights at the Door": The James Bay and Nisga'a Agreements in Canada, online: wlu

$<$ http://www.wlu.ca/ - wwwpress/jls/cjps/issues/33.2/rynard.html > (last modified: 10 August 2000).

Sanders D., Prior Claims: Aboriginal People in the Constitution of Canada, 1981 [unpublished, archived at the Library of Indian and Northern Affairs].

Schulmann B., "Getting Treaty Talks Off Square One", Policy Options Paper (October 2000). at 59-62.

Schmitz, C., "Land claims not court"s turf", The Edmonton Journal (15 January 2001) A3.

Slattery B., Ancestral Lands, Alien Laws, (Saskatchewan: Native Law Centre, 1983).

Slattery B., "The Organic Constitution", (1995) 39 Osgoode Hall L. J. 103.

Slattery B., The Hidden Constitution: Aboriginal Rights in Canada, rough draft, prepared for the American Journal of Comparative Law (date unknown).

SlatteryB., "The Nature of Aboriginal Title," in O. Lippert ed., Beyond the Nass Valley: National Implications of the Supreme Court's Delgamuukw Decision (Vancouver: Fraser Institute, 2000), pp. 11-33

Slowely G., "Aboriginal Self-Government, Extinguishment of Title and the Canadian State: Effectively Removing the 'Other'?" (2000) 1 Native Studies Review 1 at 12.

Stavenhagen R., The Ethnic Question; Conflicts, Development and Human Rights, (New York: 17 United Nations University Press, 1990) at 87.

Statistics Canada, 1996 Census - National Tables: Aboriginal, (1996) online: Statistic Canada: $<$ http://www.statcan.ca/english/census96/jan13/group.htm $>$ (last modified: 30 August 2002).

Stevenson G., Unfulfilled Union: Canadian Federalism and National Unity, $3^{\text {rd }}$ ed., (Trenton: Gage Educational Publishing Company, 1986).

Stewart H., "Models of Co-existence: A View from the Canadian Situation", online:

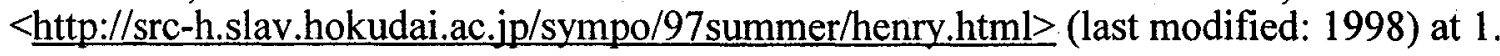

Tehan M., "Co-existence of Interest in Land: A Dominant Feature of the Common Law" (1997), online: Native Titles Research Unit

<http:www.aiatsis.gov.au/ntpapers/ntip12.htm> (last modified: 1997). 
Tennant C. and Turpel M.E., A Case Study of Indigenous Peoples: Genocide, 16 Ethnocide and Self-determination, [1991] Nordic Journal International Law 287.

The Library of Parliament, Aboriginal Rights and Land Claims, (Background Paper) by G. Schmitz (Ottawa: Library of Parliament, 1982).

Thom B., "Aboriginal Rights and Title in Canada After Delgammukw: Anthropological Perspectives" (1999) online: home.istar <http://home.istar.ca/\%7Ebthom/rights.html $>$ (last modified: September 1999).

Treasury Board of Canada Secretariat, Canada's Performance 2004: Aboriginal People, online: TBS <http://www.tbs-sct.gc.ca/report/goverev/04/cp-rc e.asp. > (last modified: 17 September 2004) at IV.

Underhill B., "Memo warns of native, non-native conflict risk" The Chronicle-Herald (17 January 2001) A3.

Union of British Columbia Indian Chiefs, "Certainty: Canada's Struggle to Extinguish Aboriginal Title", online: ubcic

<http://www.ubcic.bc.ca/certainty.htm $>$ (last modified: 05 January 2004).

United Nations Development Programme, "Human Development Report 2004: Cultural Liberty in Today's Diverse World" (2004) online: Human Development Report

<http://hdr.undp.org/hd/> (date accessed: 19 January 2005).

United Nations, Commission on Human Rights, Human Rights and Indigenous Issues: Report of the Special Rapporteur on the situation of human rights and fundamental freedoms of Indigenous people, by Mr. Rodolfo Stavenhagen, 2 December 2004.

Webster's New Dictionary and Thesaurus, concise ed., s.v. "reconcile".

Whiteside D., and Whiteside S., "Indians in Upper Canada from 1846 through 1885 , with special reference to half-breed Indians and the development of political associations. The Circle is Broken." (Ottawa: Aboriginal Title Research Group, 1979) [unpublished, archived at the Library of Indian and Northern Affairs].

Widdowson F., Separate but Unequal: The Political Economy of Aboriginal Dependency, Presentation for the Annual Conference of the Canadian Political Science Association, June 1, 2003.

Williams K., "Conservation laws weren't made for Indians" The [Montreal] Gazette (20 September 2000) Editorial. 
Williams R., The American Indian in Western Legal Thought, (New York: Oxford University Press Inc., 1990).

Windspeaker News, "“Certainty' model causes concern" (2002) online:

$<$ http://wwwammsa.com/windspeaker/topnews-Oct-2002.html>, (date accessed: 15 December 2004).

Youngblood Henderson J., "Empowering Treaty Federalism in Postcolonial Canada" (1994) [unpublished, archived at the Library of Indian and Northern Affairs] 36 at 139. 


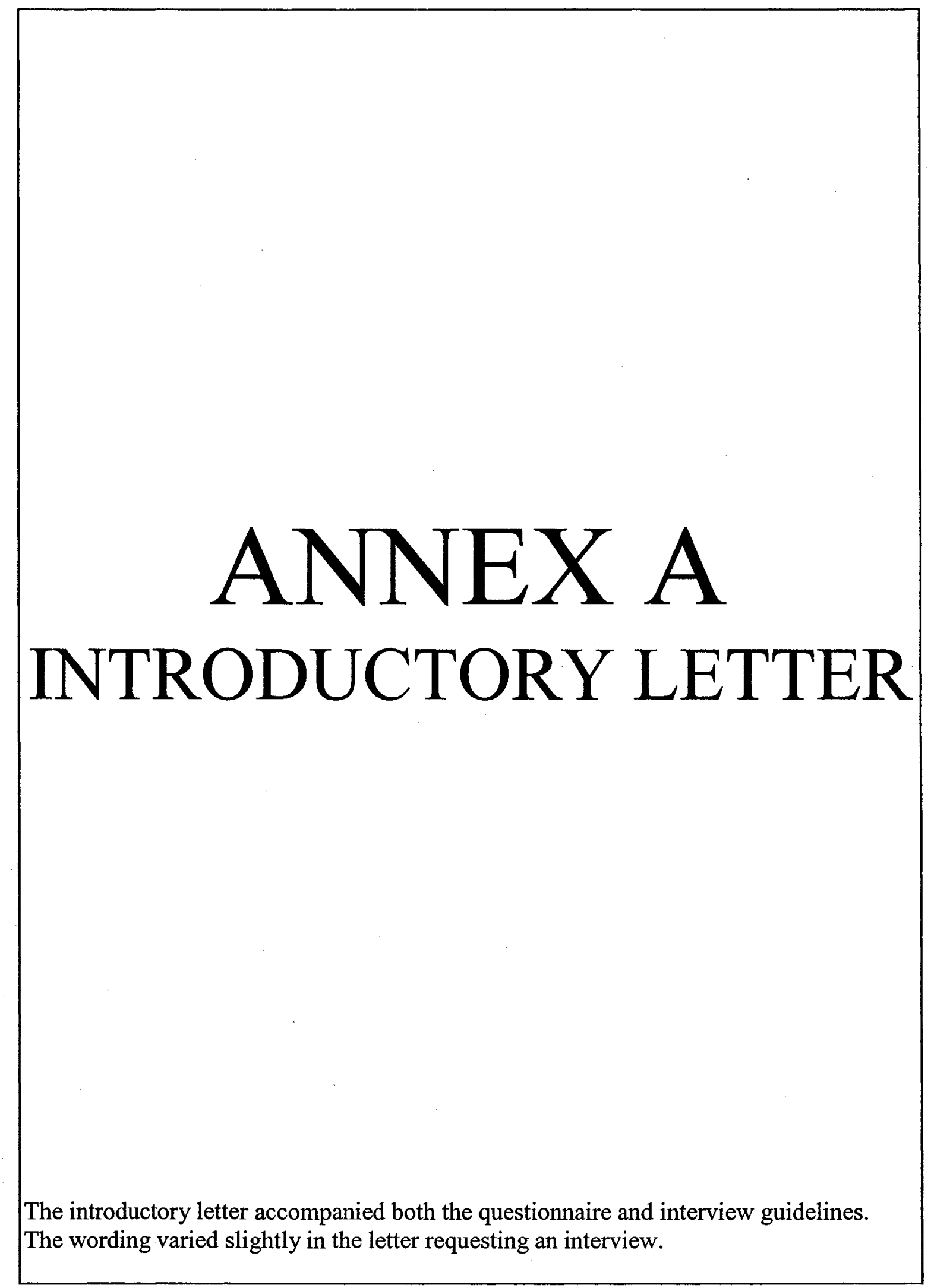


Kelly Kutchaw-Polak

Address

City/Town, Province, Postal Code

$\mathrm{Mr} / \mathrm{Mrs} / \mathrm{Chief}$

Address

City/Town, Province, Postal Code

\section{Dear Sir/Madam/Chief,}

My name is Kelly Kutchaw-Polak and I am currently enrolled in the Master of Arts (MA) Legal Studies program at Carleton University. As part of the MA requirements, I need to prepare and submit an original and independent research thesis on a topic of my choice. Subsequently, I have chosen to write on the issue of certainty

(ie., cede/release/extinguish, etc) in relation to the settlement of historical and modernday treaties.

The scope of my thesis is to ascertain if an alternative method of certainty could be developed that would recognize the interests of all parties without Aboriginal groups having to "give up" rights. In searching for an answer, I will also be exploring what methods have been deployed in the past to achieve certainty in relation to land claim settlements.

I first became interested in the notion of certainty when I started working for the Comprehensive Claims Branch at Indian and Northern Affairs Canada (INAC) in 2000. While I am still employed with INAC, the information obtained from your completed questionnaire will not be shared with INAC, other federal/provincial/ territorial departments/agencies, and/or other Aboriginal groups. The information gathered from this questionnaire (interview) will be reported at the aggregate level and individual identities/responses will not be identified without expressed written consent. All records of participation will be kept strictly confidential, such that only I and my supervisor will have access to the information.

The questionnaire (interview guideline) contains seven questions consisting of "yes/no" answers, open-ended questions and a sliding scale method. Questions have been formulated based on work and recommendations from the Hamilton Report, Royal Commission on Aboriginal People and Assembly of First Nations. It may be filled out by hand or by using the diskette provided. At anytime if you 
$-2-$

feel uncomfortable answering a question please mark N/A in the response area. (If at anytime you feel uncomfortable responding to a question during the interview process you may indicate so and we will proceed to the next question).

While I feel the issue of certainty in relation to settling land claims is important and in need of further exploration, this questionnaire is completely voluntary. Upon completion and defence, my thesis will be archived in the Carleton University Library. It is at that time that I would be happy to send you a completed copy.

If you have any questions or concerns regarding this letter and questionnaire, you may contact myself at (613) XXX-XXXX or by email at kkpolak@connect.carleton.ca or my thesis supervisor Peter Swan at (613) XXX-XXXX or by email at peter swan@carleton.ca. Questions about the right of research subjects can be addressed to the Ethics Committee Chair, Professor Klaus Pohle via email klaus_pohle@carleton.ca or telephone

(613) XXX-XXXX.

I thank you in advance for your cooperation in assisting me to complete my Master of Arts Legal Study thesis.

Sincerely,

Kelly Kutchaw-Polak

MA Legal Studies Candidate 


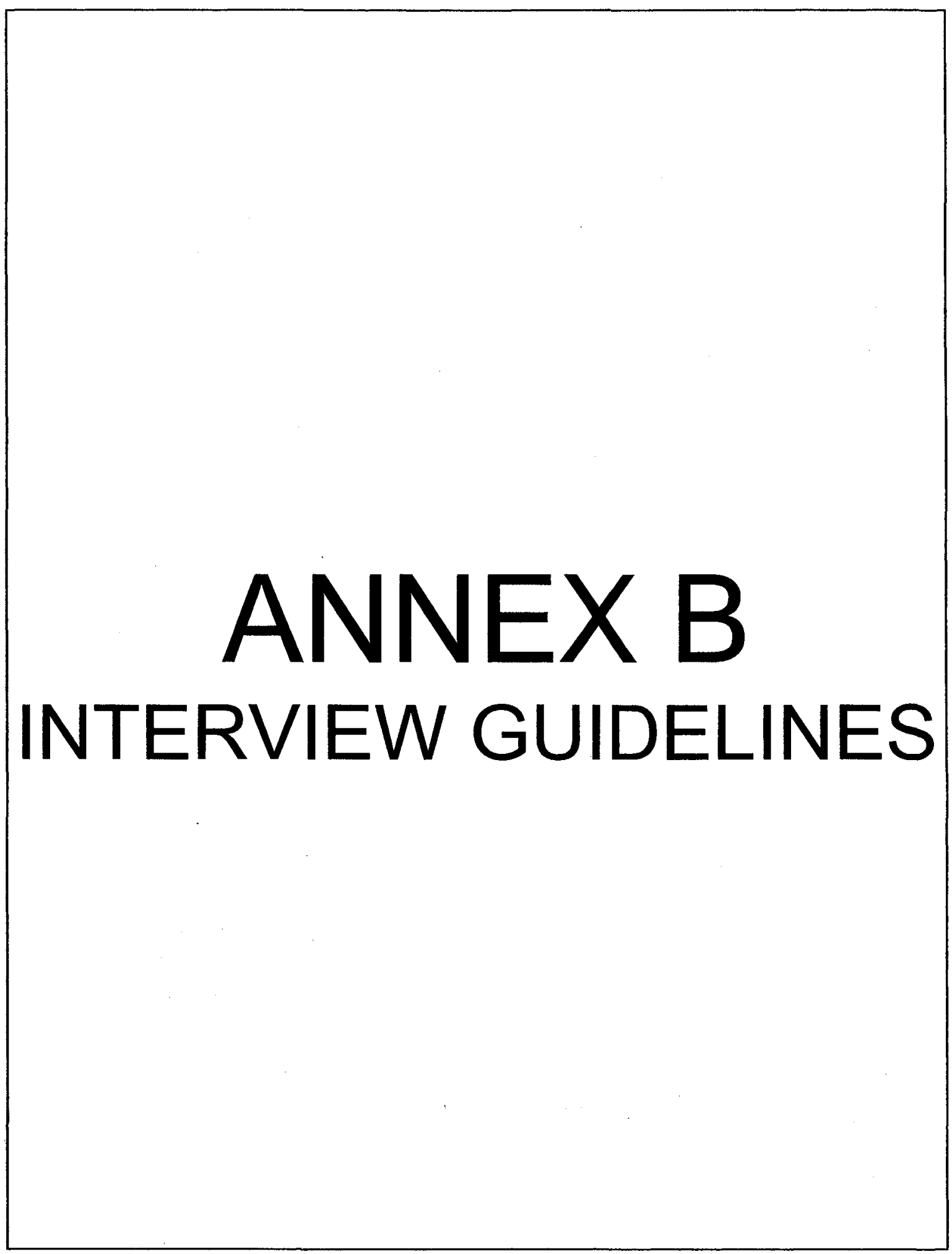




\section{CERTAINTY INTERVIEW GUIDE}

1. How important do you feel achieving certainty is when settling a land claim?

2. Do you feel the current method deployed to achieve certainty takes into consideration the interests of all parties? Please explain.

3. Do you feel an alternative method of certainty could be developed without Aboriginal groups having to cede, release, surrender, extinguish, or modify any rights? Please explain.

4. Please rank how important you feel the statements noted below are to the achievement of certainty. (1 strongly disagree and 10 strongly agree).

A. All parties know exactly what their rights are, and that these rights will not be denied through assertion by others of unanticipated, conflicting rights.

$$
2
$$

3

4

5

6

7

8

9

B. All parties know the extent of the rights of others.

2

3

4

5

6

7

8

9

10

C. All parties know that their rights will be respected by all.

1

2

3

4

5

6

7

8

9

10

D. All parties know that the treaty obligations will be met by all.

1

23

3

4

5

6

7

8

9

10 


\section{CERTAINTY INTERVIEW GUIDE}

E. All parties know where, how, and under what conditions their rights can be exercised.

$\begin{array}{llllllllll}1 & 2 & 3 & 4 & 5 & 6 & 7 & 8 & 9 & 10\end{array}$

F. All know how, and from whom, new rights can be obtained.

$\begin{array}{llllllllll}1 & 2 & 3 & 4 & 5 & 6 & 7 & 8 & 9 & 10\end{array}$

G. All parties have the confidence to undertake long-term planning for investments or other purposes.

$\begin{array}{llllllllll}1 & 2 & 3 & 4 & 5 & 6 & 7 & 8 & 9 & 10\end{array}$

H. All parties know that there will be a stable and predictable environment for economic development.

$\begin{array}{llllllllll}1 & 2 & 3 & 4 & 5 & 6 & 7 & 8 & 9 & 10\end{array}$

I. All parties know that there is a process in place to resolve disputes among the parties.

$\begin{array}{llllllllll}1 & 2 & 3 & 4 & 5 & 6 & 7 & 8 & 9 & 10\end{array}$

5. Comments 


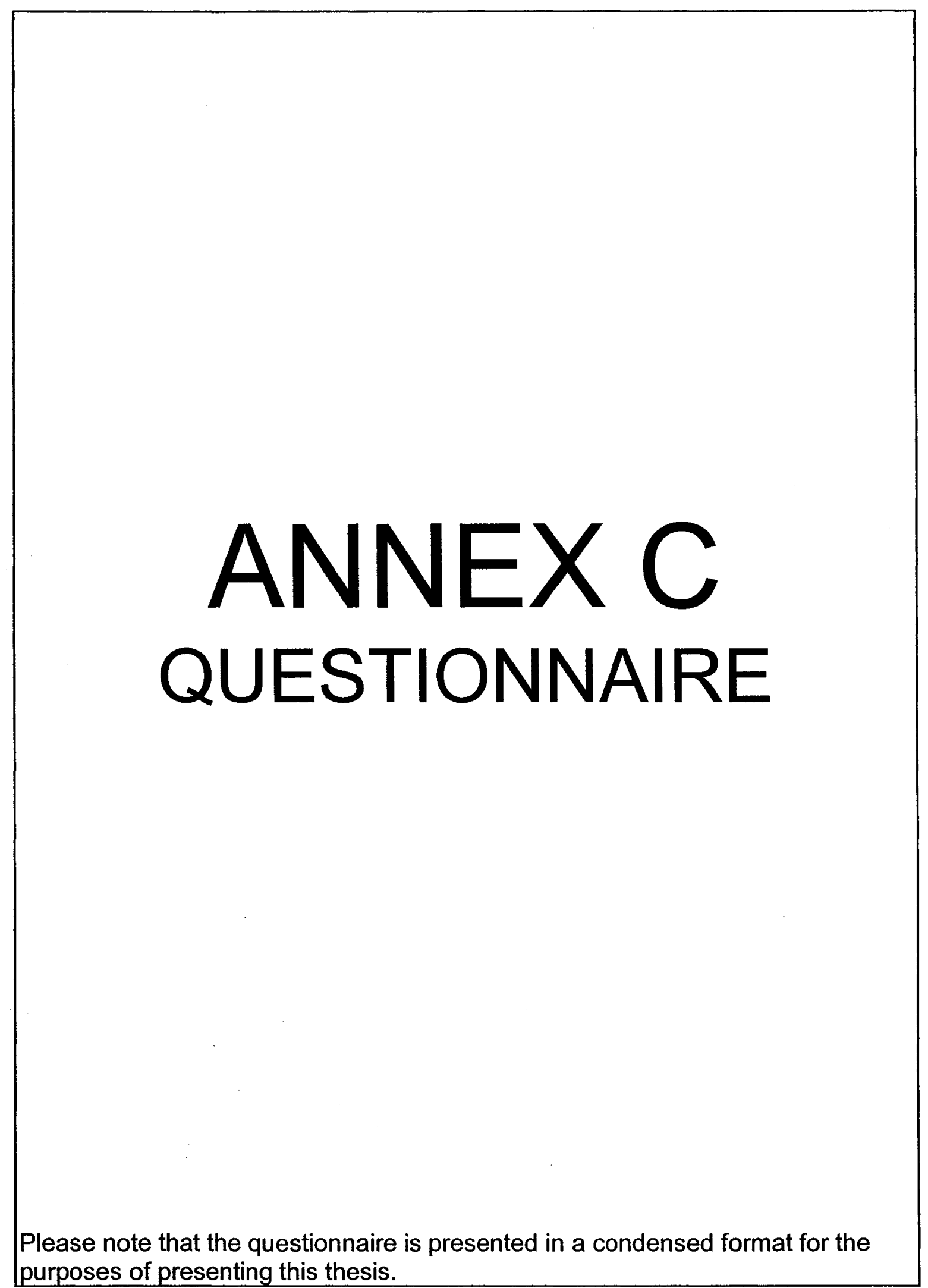




\section{Certainty Questionnaire}

According to the 1984 Comprehensive Land Claims Policy," the purpose of settlement agreements is to provide certainty and clarity to ownership and use of land and resources in those areas of Canada where Aboriginal title has not been dealt with by treaty or superseded by law. Final settlements must therefore result in certainty and predictability with respect to the use and disposition of lands affected by the settlement".

1. Do you agree with the above notion of certainty?

$\square$ Yes $\square$ No

2. Using the list below, please identify which certainty provision(s) your settled land claim agreement contains:

cede, release and surrender

partial surrender

modification

extinguishment

3. Do you feel the certainty clause contained within your own settled land claim agreement impeded the negotiation process? If yes, please explain.

4. How important do you feel achieving certainty is when settling a land claim?

5. Do you feel that the current method use to achieve certainty takes into consideration the interests of all parties? Please explain.

6. Do you feel an alternative method of certainty could be developed without Aboriginal groups having to cede, release, surrender, extinguish, or modify any rights? Please explain. 
Certainty Questionnaire

7. Please rank how important you feel the statements noted below are to the achievement of certainty. ( 1 strongly disagree and 10 strongly agree).

A. All parties know exactly what their rights are, and that these rights will not be denied through assertion by others of unanticipated, conflicting rights.

1

$$
2
$$

3

4

5

6

7

8

9

10

B. All parties know the extent of the rights of others.

1

2

3

4

5

6

7

8

9

10

C. All parties know that their rights will be respected by all.

1

23

45

6

7

8

9

10

D. All parties know that the treaty obligations will be met by all.

1

2

3

4

5

6

7

8

9

10

E. All parties know where, how, and under what conditions their rights can be exercised.

1

2

3

4

5

6

7

8

9

10

F. All know how, and from whom, new rights can be obtained.

1

23

4

5

6

7

8

9

10 
Certainty Questionnaire

G. All parties have the confidence to undertake long-term planning for investments or other purposes.

$\begin{array}{llllllllll}1 & 2 & 3 & 4 & 5 & 6 & 7 & 8 & 9 & 10\end{array}$

H. All parties know that there will be a stable and predictable environment for economic development.

1

2

3

4

5

6

7

8

9

10

I. All parties know that there is a process in place to resolve disputes among the parties.

1

23

4

5

6

7

8

9

10

8. Comments 


\section{ANNEX D CONSENT FORM}




\section{Consent Form}

The purpose of this study is to ascertain varying opinions regarding the development of an alternative model of certainty in the settlement of modern-day treaties which will be used to assist in the completion of my Masters of Arts Legal Studies Thesis at Carleton University, Ottawa. Before completing the questionnaire/interview, we would like you to read and then sign this consent form, indicating that you understand the potential risk and benefits of participation, and that you understand your rights as a participant.

\section{Risks}

There is little or no risk to you in filling out this questionnaire (participating in this interview). Your responses are completely confidential.

\section{Benefits}

Although the results of this research may benefit future academic research, there is no direct benefit to you by participating in this study.

\section{Confidentiality of Responses}

I understand that the purpose of this study is to ascertain varying opinions regarding the development of an alternative model of certainty in the settlement of modern-day treaties.

I further understand that any information collected during this study will be held in the strictest confidence. Only the primary researcher and/or academic supervisor will have access to the confidential raw data.

\section{Right to Withdraw or Decline to Participate}

I understand that my participation in this study is strictly voluntary and I may discontinue my participation at any time without prejudice.

Note: Questions or concerns about the research study should be addressed to Kelly Kutchaw-Polak via email kkpolak@connect.carleton.ca or telephone (613) XXX-XXX, or the thesis supervisor, Professor Peter Swan via email peter swan@carleton.ca or telephone (613) $X X X-X X X X$. Questions about the right of research subjects can be addressed to the Ethics Committee Chair, Professor Klaus Pohle via email klaus pohle@carleton.ca or telephone (613) XXX-XXXX.

I attest that I have read and understood the above description, including potential risks, benefits and my rights as a participant, and that all of my questions about the study have been answered to my satisfaction. I hereby give my informed consent to participate in this research study.

\section{Signature of participant:}

Date: 


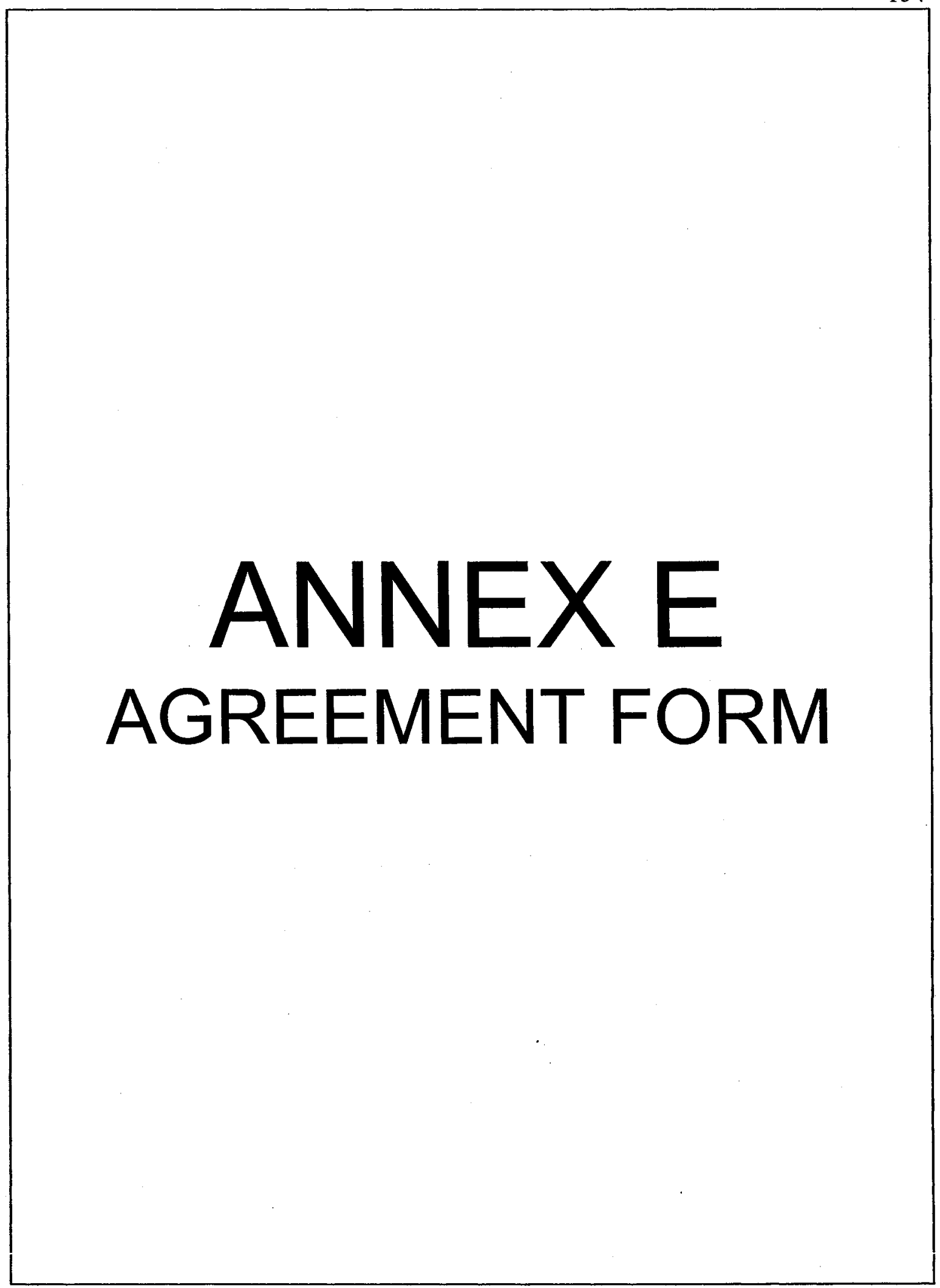




\section{Agreement}

Researcher: Kelly Kutchaw-Polak, M.A. Legal Studies Candidate

Address

City/Town, Province, Postal Code

Thank you for agreeing to participate in this study which will take place from (November $1,2003$ ) to (November 1,2004$)$. This form outlines the purpose of the study and provides a description of your involvement and rights as a participant.

The purposes of this study are:

a) to ascertain varying opinions regarding the development of an alternative model of certainty in the settlement of modern-day treaties.

b) to assist in the completion of my Masters of Arts Legal Studies Thesis at Carleton University, Ottawa.

The methods to be used to collect information for this study are explained below. This information will be analysed and may assist in developing an alternative model to achieve certainty in modern-day treaties.

The questionnaire contains seven questions consisting of "yes/no" answers, open-ended questions and a sliding scale method. It may be filled out by hand or by using the diskette provided. At anytime if you feel uncomfortable answering a question please mark N/A in the response area.

The interview will consist of seven questions consisting of "yes/no" answers, open-ended questions and a sliding scale method. At anytime if you feel uncomfortable answering a question you are encouraged to state so an N/A will be marked in the response area. You are also encouraged to ask any questions at any time about the nature of the study and the methods that I am using. Your suggestions and concerns are important to me; please contact me at any time at the address listed above or by phone at (613) XXXXXXX.

I guarantee that the following conditions will be met:

a) to comply with the Guidelines of the Social Sciences and Humanities Research Council of Canada.

b) that at all times while working on this study I will be under the direct supervision of a faculty member at Carleton University. 
e) although I work for the Department of Indian and Northern Affairs Canada, none of the data collected will be shared with the Department or any other federal/provincial/territorial departments/agencies or any other Aboriginal groups or organizations, without express written consent of the parties involved in this study.

f) the data collected will be reported at the aggregate level and individual identities/responses will not be reported without express written consent of the parties involved in this study.

g) the interview/questionnaire is completely voluntary and the individuals may withdraw at anytime throughout the process.

h) upon your request provide you with a copy of my thesis upon its completion and defence.

I agree to the terms

Researcher's signature Date Date 


\section{TERMS}

Eight important terms have been identified and should be explained in connection to the research and subsidiary questions put forth by this proposal.

\section{Aboriginal People}

The generic term "Aboriginal people/groups/communities" will be used throughout this paper and is meant to include Indians, Métis, and Inuit peoples throughout Canada, as recognized by section 35 of the Constitution Act. Where the term "First Nations" is used, it specifically refers to Aboriginal communities/groups/ governments that exclude Inuit and Métis. The reason for this distinction is that the government of British Columbia restricts its negotiations to First Nations and to those organizations that exclude Inuit and Métis interests. However, it should also be noted that the term First Nations has replaced the term Indian in most governmental documents and academic literature. Where the term "Indian" is used, it specifically refers to Aboriginals in either a historical context or in legislative materials.

\section{Aboriginal Beneficiaries}

"Aboriginal beneficiaries" refers to any First Nation, Métis or Inuit person who benefits from a legislated agreement by asserting an aboriginal title to lands within the settlement area based on traditional use and occupancy of land, is of Indian ancestry, and is a Canadian citizen. ${ }^{1}$ In some agreements, an amount is indicated as to what percentage of Indian ancestry the beneficiary must have. ${ }^{2}$

\footnotetext{
1 Wording is a summary of that which is contained in the various land claim agreements. For examples see: the Western Arctic (Inuvialuit) Claims Settlement Act, S.C, 1984, c. 24 and Yukon First
} 


\section{Aboriginal Organizations}

"Aboriginal organizations" refer to those entities, such as the Assembly of First Nations, Congress of Aboriginal People, Council for the Advancement of Native Development, Inuit Tapirisat of Canada, National Métis Council, and the Native Women's Association of Canada, who advocate on behalf of First Nations, Métis, Inuit and Innu.

\section{Certainty}

As previously stated, in its simplest form, certainty is used to clarify each party's position and rights in relation to the land base and rights being claimed. Certainty was, and is, a tumultuous issue between Aboriginal groups, the federal and provincial governments, and third parties when negotiating land claim agreements. For its part, the government seeks finality and clarity through the form of cede, release, surrender or modification. In contrast, Aboriginal groups seek a model of certainty that promotes an ongoing relationship through recognition of existing and future rights.

\section{The Crown}

For the purpose of this thesis, the Crown refers to those federal/provincial/territorial departments and central agencies (e.g., the Privy Council's Office) that are responsible for addressing Aboriginal issues on behalf of Canada as a sovereign state. Without exploring the intricacies of government, it must be noted that while INAC is the lead department mandated to address First Nations and Inuit issues, other federal and provincial departments and central agencies play a key role in advising,

Nations Land Claims Settlement Act, S.C., 1994, c. 34

2 Ibid. 
inputting and approving land claim agreements. As such, any recommendations that speak of the Crown are referring to the collective group of federal/provincial/territorial governments and central agencies.

\section{Modern-day treaties}

"Modern-day treaties/agreements", or "comprehensive land claims", are defined according to the Comprehensive Land Claims Policy, as those claims "based on the concept of continuing Aboriginal rights and title which have not been dealt with by treaty or other legal means". 3 The term comprehensive land claims, used to describe modernday treaties, denotes the variety of rights such as hunting, fishing, trapping, land, resource management, moneys, etc., that are protected in exchange for a release of title. In light of the fact that no other definition appears to dispute the Federal government's understanding of what constitutes a modern-day treaty, this definition will be adopted. The words treaty, claim and agreement will be interchanged throughout this paper.

\section{Historical Treaties}

"Historical treaties" are those treaties signed prior to the establishment of the 1973 Comprehensive Land Claims Policy. They were negotiated between Aboriginal people and the Canadian Government (originally the British Crown) between 1725 and 1923. Historical treaties have subsequently been divided into two categories. The first category, Pre-Confederation Treaties, includes all the treaties made before Confederation. The second category is the Numbered Treaties, which are post-confederation numbered 1 to 11 .

3 Department of Indian Affairs and Northern Development, (1993) Federal Policy for the Settlement of Native Claims, Minister of Indian Affairs and Northern Development, Ottawa, at I. 


\section{Treaty Rights}

"Treaty rights" are defined as those rights such as land and resource usage, royalties, hunting, gathering, fishing, and financial compensation, which are contained within both historical and modern-day final settlement agreements. Treaty rights are exercised by the beneficiaries within the settlement area or as laid out in the treaty. 


\section{APPENDIX 2}

The following chart outlines the certainty and extinguishment provisions in the nineteen settled/initialled land claim agreements between Canada, the provinces/territories and various Aboriginal groups.

\begin{tabular}{|l|l|l|}
\hline \multicolumn{2}{|c|}{ CERTAINTY \& EXTINGUISHMET PROVISONS IN COMPREHENSIVE LAND CLAIM AGREEMENTS } \\
\hline \multicolumn{2}{|c|}{ FINAL AGREEMENTS } & $\begin{array}{l}\text { CERTAINTY PROVISIONS/EXTINGUISHMENT PROVISIONS } \\
\text { (prior to 1986) }\end{array}$ \\
\hline 2004 & Tlicho Final Agreement & $\begin{array}{l}\text { Non Assertion: } \\
\text { Except as provided in s.2.6.1, the Tlicho will not exercise or assert } \\
\text { any Aboriginal or treaty rights, other than: } \\
\text { a) any rights set out in the Agreement; or } \\
\text { (b) the Treaty 11 rights respecting annual payments to } \\
\text { the Indians and payments of the salaries of teachers to } \\
\text { instruct the children of the Indians. }\end{array}$ \\
\hline 2003 & Kluane First Nation Final Agreement & $\begin{array}{l}\text { s. 2.5.0 Certainty } \\
\text { s.2.5.1.1: "subject to 5.14.0, that Yukon First Nation and all persons } \\
\text { who are eligible to be Yukon Indian People it represents, as of the } \\
\text { Effective Date of that Yukon First Nation's Final Agreement, cede, } \\
\text { release and surrender to Her Majesty the Queen in Right of Canada, } \\
\text { all their aboriginal claims, rights, title and interests ..." }\end{array}$ \\
\hline $\begin{array}{l}\text { 2003 } \\
\text { (initialed) }\end{array}$ & Carcoss/Tagish Final Agreement & $\begin{array}{l}\text { s. 2.5.0 Certainty } \\
\text { s.2.5.1.1: "subject to 5.14.0, that Yukon First Nation and all persons } \\
\text { who are eligible to be Yukon Indian People it represents, as of the } \\
\text { Effective Date of that Yukon First Nation's Final Agreement, cede, } \\
\text { release and surrender to Her Majesty the Queen in Right of Canada, } \\
\text { all their aboriginal claims, rights, title and interests ..." }\end{array}$ \\
\hline
\end{tabular}




\begin{tabular}{|c|c|c|}
\hline 2002 & Ta'an Kwach'an Final Agreement & $\begin{array}{l}\text { s. 2.5.0 Certainty } \\
\text { s.2.5.1.1: "subject to 5.14.0, that Yukon First Nation and all persons } \\
\text { who are eligible to be Yukon Indian People it represents, as of the } \\
\text { Effective Date of that Yukon First Nation's Final Agreement, cede, } \\
\text { release and surrender to Her Majesty the Queen in Right of Canada, } \\
\text { all their aboriginal claims, rights, title and interests ..." }\end{array}$ \\
\hline 1999 & Nisga'a Final Agreement & $\begin{array}{l}\text { Modification: } \\
\text { s. } 24 \text { "Notwithstanding the common law, as a result of this } \\
\text { Agreement and the settlement legislation, the aboriginal rights, } \\
\text { including the aboriginal title, of the Nisga'a Nation....are modified, as } \\
\text { set out in this Agreement." } \\
\text { s. } 25 \text { "For greater certainty, the aboriginal title of the Nisga'a } \\
\text { Nation...is modified..." }\end{array}$ \\
\hline 1998 & Tr'ondëk Hwëch'in Final Agreement & $\begin{array}{l}\text { s. 2.5.0 Certainty } \\
\text { s.2.5.1.1: "subject to 5.14.0, that Yukon First Nation and all persons } \\
\text { who are eligible to be Yukon Indian People it represents, as of the } \\
\text { Effective Date of that Yukon First Nation's Final Agreement, cede, } \\
\text { release and surrender to Her Majesty the Queen in Right of Canada, } \\
\text { all their aboriginal claims, rights, title and interests ..." }\end{array}$ \\
\hline 1997 & Little Salmon/Carmacks Final Agreement & $\begin{array}{l}\text { s. 2.5.0 Certainty } \\
\text { s.2.5.1.1: "subject to 5.14.0, that Yukon First Nation and all persons } \\
\text { who are eligible to be Yukon Indian People it represents, as of the } \\
\text { Effective Date of that Yukon First Nation's Final Agreement, cede, } \\
\text { release and surrender to Her Majesty the Queen in Right of Canada, } \\
\text { all their aboriginal claims, rights, title and interests ..." }\end{array}$ \\
\hline 1997 & Selkirk First Nation Final Agreement & $\begin{array}{l}\text { s. 2.5.0 Certainty } \\
\text { s.2.5.1.1: "subject to 5.14.0, that Yukon First Nation and all persons }\end{array}$ \\
\hline
\end{tabular}




\begin{tabular}{|c|c|c|}
\hline & & $\begin{array}{l}\text { who are eligible to be Yukon Indian People it represents, as of the } \\
\text { Effective Date of that Yukon First Nation's Final Agreement, cede, } \\
\text { release and surrender to Her Majesty the Queen in Right of Canada, } \\
\text { all their aboriginal claims, rights, title and interests ..." }\end{array}$ \\
\hline $\begin{array}{l}1993 \\
\text { (effective } \\
\text { date 1994) }\end{array}$ & $\begin{array}{l}\text { Sahtu Dene and Métis Comprehensive Land } \\
\text { Claim Agreement }\end{array}$ & $\begin{array}{l}\text { s.3.1.11 "In consideration of the rights and benefits provided to the } \\
\text { Sahtu Dene and Métis by this agreement, the Sahtu Dene and Métis } \\
\text { cede, release and surrender to Her Majesty the Queen in Right of } \\
\text { Canada, all their aboriginal claims, rights, title and interests, if any, in } \\
\text { and to lands and waters anywhere within Canada. }\end{array}$ \\
\hline $\begin{array}{l}1993 \\
\text { (effective } \\
\text { date 1995) }\end{array}$ & $\begin{array}{l}\text { Vuntut Gwitchin First Nation Final } \\
\text { Agreement }\end{array}$ & $\begin{array}{l}\text { s. 2.5.0 Certainty } \\
\text { 2.5.1.1 "subject to 5.14.0, that Yukon First Nation and all persons } \\
\text { who are eligible to be Yukon Indian People it represents, as of the } \\
\text { Effective Date of that Yukon First Nation's Final Agreement, cede, } \\
\text { release and surrender to Her Majesty the Queen in Right of Canada, } \\
\text { all their aboriginal claims, rights, title and interests, in and to..." }\end{array}$ \\
\hline $\begin{array}{l}1993 \\
\text { (effective } \\
\text { date 1995) }\end{array}$ & $\begin{array}{l}\text { Champagne and Aishihik First Nations Final } \\
\text { Agreement }\end{array}$ & $\begin{array}{l}\text { s. 2.5.0 Certainty } \\
\text { 2.5.1.1 "subject to 5.14.0, that Yukon First Nation and all persons } \\
\text { who are eligible to be Yukon Indian People it represents, as of the } \\
\text { Effective Date of that Yukon First Nation's Final Agreement, cede, } \\
\text { release and surrender to Her Majesty the Queen in Right of Canada, } \\
\text { all their aboriginal claims, rights, title and interests, in and to..." }\end{array}$ \\
\hline $\begin{array}{l}1993 \\
\text { (effective } \\
\text { date 1995) }\end{array}$ & Teslin Tlingit Council Final Agreement & $\begin{array}{l}\text { s. 2.5.0 Certainty } \\
\text { 2.5.1.1 "subject to 5.14.0, that Yukon First Nation and all persons } \\
\text { who are eligible to be Yukon Indian People it represents, as of the } \\
\text { Effective Date of that Yukon First Nation's Final Agreement, cede, } \\
\text { release and surrender to Her Majesty the Queen in Right of Canada, } \\
\text { all their aboriginal claims, rights, title and interests, in and to..." }\end{array}$ \\
\hline
\end{tabular}




\begin{tabular}{|c|c|c|}
\hline $\begin{array}{l}1993 \\
\text { (effective } \\
\text { date 1995) }\end{array}$ & $\begin{array}{l}\text { Nacho Nyak Dun First Nation Final } \\
\text { Agreement }\end{array}$ & $\begin{array}{l}\text { s. 2.5.0 Certainty } \\
\text { 2.5.1.1 "subject to 5.14.0, that Yukon First Nation and all persons } \\
\text { who are eligible to be Yukon Indian People it represents, as of the } \\
\text { Effective Date of that Yukon First Nation's Final Agreement, cede, } \\
\text { release and surrender to Her Majesty the Queen in Right of Canada, } \\
\text { all their aboriginal claims, rights, title and interests, in and to..." }\end{array}$ \\
\hline 1993 & $\begin{array}{l}\text { Umbrella Final Agreement between the } \\
\text { Government of Canada, the Council for } \\
\text { Yukon Indians and the Government of the } \\
\text { Yukon }\end{array}$ & $\begin{array}{l}\text { s, 2.5.0 Certainty } \\
\text { 2.5.1.1 "subject to 5.14.0, that Yukon First Nation and all persons } \\
\text { who are eligible to be Yukon Indian People it represents, as of the } \\
\text { Effective Date of that Yukon First Nation's Final Agreement, cede, } \\
\text { release and surrender to Her Majesty the Queen in Right of Canada, } \\
\text { all their aboriginal claims, rights, title and interests, in and to..." }\end{array}$ \\
\hline $\begin{array}{l}1993 \\
\text { (effective } \\
\text { date 1994) }\end{array}$ & Nunavut Land Claims Agreement & $\begin{array}{l}\text { Part 7: Certainty } \\
2.7 .1 \text { "In consideration of the rights and benefits provided to Inuit by } \\
\text { the Agreement, Inuit hereby: } \\
\text { (a) cede, release and surrender to Her Majesty the Queen in Right of } \\
\text { Canada all their aboriginal claims, rights, title and interests, if } \\
\text { any...within the sovereignty and jurisdiction of Canada } \\
\text { (b)agree, on their behalf, and on behalf of their heirs, descendants and } \\
\text { successors not to assert any cause of action..." }\end{array}$ \\
\hline 1992 & $\begin{array}{l}\text { The Gwich'in Comprehensive Land Claim } \\
\text { Agreement }\end{array}$ & $\begin{array}{l}\text { 3.1.12 "In consideration of the rights and benefits provided to the } \\
\text { Gwich'in by the agreement, the Gwich'in cede, release and surrender } \\
\text { to Her Majesty the Queen in Right of Canada all their aboriginal } \\
\text { claims, rights, title and interests, if any...anywhere within Canada." }\end{array}$ \\
\hline 1984 & $\begin{array}{l}\text { The Western Arctic Claim: The Inuvialuit } \\
\text { Final Agreement }\end{array}$ & $\begin{array}{l}\text { s.3 (4) "...the Inuvialuit cede, release, surrender and convey all their } \\
\text { aboriginal claims, rights, title and interests, whatever they may be in } \\
\text { and to...withing the sovereignty or jurisdiction of Canada." }\end{array}$ \\
\hline
\end{tabular}




\begin{tabular}{|l|l|l|}
\hline 1978 & The Northern Québec Agreement & $\begin{array}{l}\text { Extinguishment: } \\
\text { s.3 (5) “...this Agreement shall extinguish all aboriginal claims, } \\
\text { rights, title and interests whatever they may be..." }\end{array}$ \\
\hline 1975 & James Bay and Northern Québec Agreement & $\begin{array}{l}\text { s.2.1. "In consideration of the rights and benefits herein set forth in } \\
\text { favour of the Naskapis of Québec, the Naskapis of Québec hereby } \\
\text { cede, release, surrender and convey all their native claims, rights, title } \\
\text { and interests..." }\end{array}$ \\
$\begin{array}{l}\text { s. 2.1 “...hereby cede, release, surrender, and convey all their Native } \\
\text { claims, rights, title and interest... to land in the Territory and in } \\
\text { Québec.." } \\
\text { s.2.6 “... extinguish all native claims, rights, title, and interests of all } \\
\text { Indians and all Inuit and to the Territory..." }\end{array}$ \\
\hline
\end{tabular}

Settled land claims pertaining 'extinguishment' provisions appear in red.

Certainty provisions appear in blue, however only the agreements explicitly using the headlining 'certainty' are listed as such. 


\section{APPENDIX 3}

\section{Research Questions and Methodology}

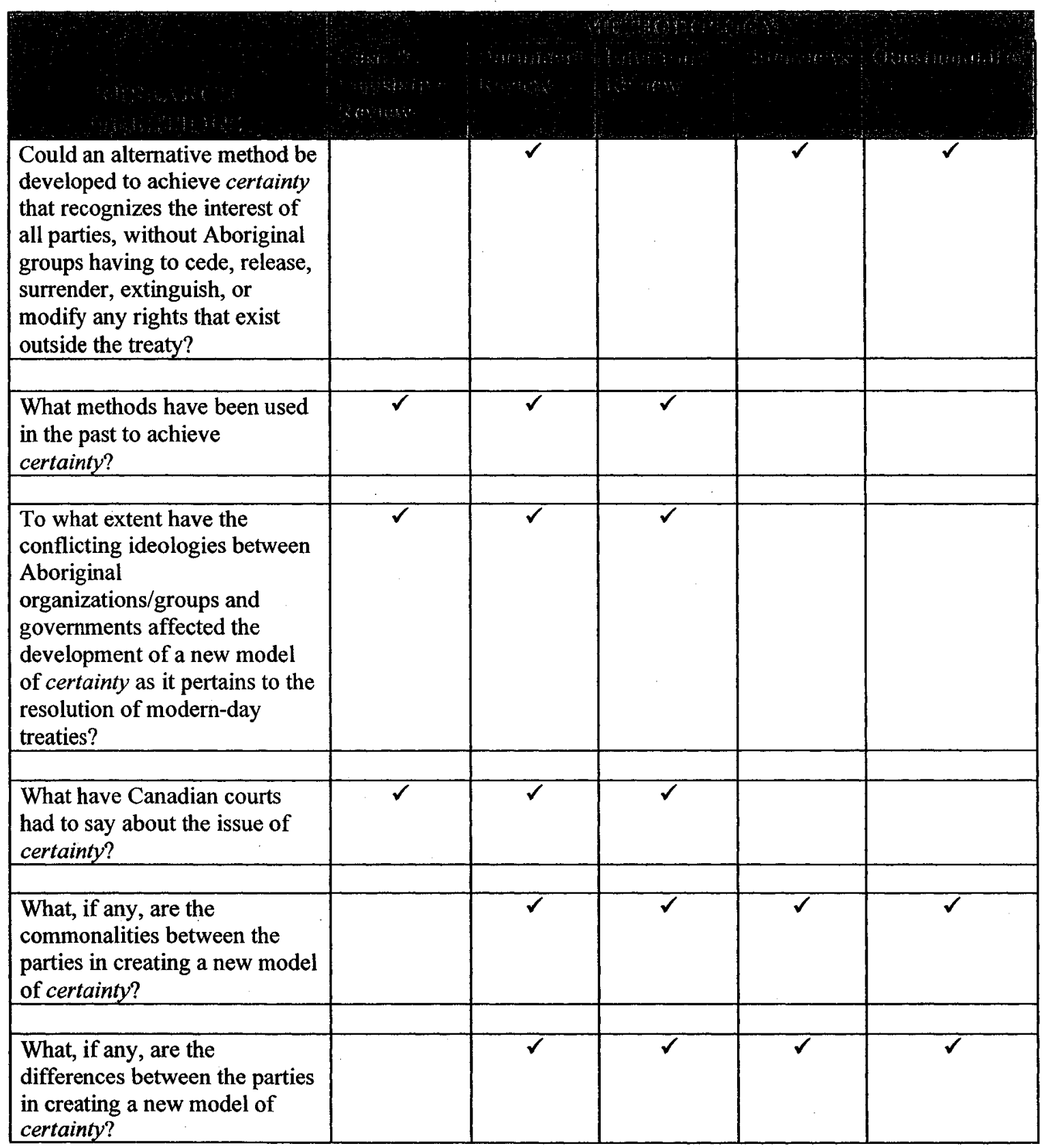




\section{APPENDIX 4}

\section{Statement of Claim}

The claims process begins with the preparation of a statement of claim and appropriate supporting materials by the claimant group. A statement of claim should contain the following elements:

1. a statement that the claimant group has not previously adhered to treaty;

2. a documented statement from the claimant group that is has traditionally used and occupied the territory in question and that this use and occupation continues;

3. a description of the extent and location of such land use and occupancy, together with a map outlining the appropriate boundaries;

4. identification of the claimant group including the names of the bands, tribes or communities on whose behalf the claim is being made, the claimant's linguistic and culture affiliation, and approximate population figures for the claimant group.

The claims process begins when the federal government accepts an Aboriginal group's statement of claim and supporting materials. The federal government will accept the claim if the statement confirms that the group claiming:

1. The Aboriginal group is, and was, an organized society.

2. The organized society has occupied the specific territory over which it asserts Aboriginal title since time immemorial. The traditional use and occupancy of the territory must have been sufficient to be an established fact at the time of assertion of sovereignty by European nations.

3. The occupation of the territory by the Aboriginal group was largely to the exclusion of other organized societies.

4. The Aboriginal group can demonstrate some continuing current use and occupancy of the land for traditional purposes. 
5. The group's Aboriginal title and rights to resource use have not been dealt with by treaty.

6. Aboriginal title has not been eliminated by other lawful means.

When the terms of the final agreement have been approved by all parties, the agreement is implemented by federal settlement legislation. The rights the Aboriginal group receives from the federal and provincial/territorial governments are protected by the Constitution and cannot be altered without the consent of the Aboriginal group.

The above is an excerpt taken from the Indian and Northern Affairs Comprehensive Land Claims Policy and website. Department of Indian Affairs and Northern Development (1987) Comprehensive Land Claims Policy, Minister of Supply and Services Canada, Ottawa, and Indian and Northern Affairs Canada, Comprehensive Claims (Modern Treaties) in Canada (March 1996) online INAC $<$ http://www.inac.gc.ca/pr/info/trty_e.html $>$ (last modified: 23 April 2004). 


\section{APPENDIX 5}

\section{COMPARISON OF HAMILTON'S MODEL AGAINST THE JAMES BAY, NISGA'A \& TLICHO FINAL AGREEMENTS}

\begin{tabular}{|c|c|c|c|}
\hline HAMILTON'S MODEL & JAMES BAY & NISGA'A & TLICHO \\
\hline \multicolumn{4}{|c|}{ RECOGNITION OF ABORIGINAL RIGTHS } \\
\hline $\begin{array}{l}\text { WHEREAS the (Aboriginal } \\
\text { group) has used and occupied } \\
\text { lands and resources in the } \\
\text { Treaty Area since time } \\
\text { immemorial. }\end{array}$ & $\begin{array}{l}\text { WHEREAS the Province of } \\
\text { Quebec assumed certain } \\
\text { obligations in favour of the } \\
\text { Native people inhabiting the } \\
\text { said areas (hereinafter referred } \\
\text { to as the "Territory"). }\end{array}$ & $\begin{array}{l}\text { WHEREAS the Nisga'a } \\
\text { Nation has lived in the Nass } \\
\text { Area since time immemorial. }\end{array}$ & $\begin{array}{l}\text { WHEREAS the Tlicho in an } \\
\text { Aboriginal people of Canada } \\
\text { that has used and occupied } \\
\text { lands in the Northwest } \\
\text { Territories from time } \\
\text { immemorial. }\end{array}$ \\
\hline $\begin{array}{l}\text { WHEREAS the parties to this } \\
\text { treaty agree the (Aboriginal } \\
\text { party) has Aboriginal rights in } \\
\text { the Treaty Area. }\end{array}$ & $\begin{array}{l}\text { WHEREAS the Province of } \\
\text { Quebec now wishes to fully } \\
\text { satisfy all of its obligations } \\
\text { with respect to the Native } \\
\text { people inhabiting the Territory } \\
\text { and the James Bay Crees, the } \\
\text { Inuit of Quebec and the Inuit of } \\
\text { Port Burwell have consented to } \\
\text { the terms and conditions of an } \\
\text { agreement of settlement... }\end{array}$ & $\begin{array}{l}\text { WHEREAS section 35of the } \\
\text { Constitution Act, } 1982 \\
\text { recognizes and affirms the } \\
\text { existing aboriginal and treaty } \\
\text { rights of the aboriginal people } \\
\text { of Canada, which the Courts } \\
\text { have stated include aboriginal } \\
\text { title. } \\
\text { WHEREAS this Agreement } \\
\text { sets out Nisga'a section } 35 \\
\text { rights inside and outside the } \\
\text { area that is identified in this } \\
\text { Agreement as Nisga'a Lands. }\end{array}$ & $\begin{array}{l}\text { WHEREAS the Constitution } \\
\text { Act, } 1982 \text { recognizes and } \\
\text { affirms the existing Aboriginal } \\
\text { and treaty rights of the } \\
\text { Aboriginal peoples of Canada }\end{array}$ \\
\hline \multicolumn{4}{|c|}{ CERTAINTY } \\
\hline $\begin{array}{l}\text { WHEREAS the parties wish to } \\
\text { achieve certainty with respect } \\
\text { to the ownership and use of } \\
\text { lands and resources dealt with }\end{array}$ & $\begin{array}{l}\text { WHEREAS, in particular, it is } \\
\text { expedient to agree upon the } \\
\text { terms and conditions of the } \\
\text { surrender of the rights referred }\end{array}$ & $\begin{array}{l}\text { WHEREAS the Parties intend } \\
\text { that this Agreement will } \\
\text { provide certainty with respect } \\
\text { to Nisga'a ownership and use }\end{array}$ & $\begin{array}{l}\text { WHEREAS the Parties have } \\
\text { negotiated this Agreement in } \\
\text { order to define and provide } \\
\text { certainty in respect of rights of }\end{array}$ \\
\hline
\end{tabular}




\begin{tabular}{|c|c|c|c|}
\hline in the treaty. & $\begin{array}{l}\text { to the } 1912 \text { Quebec Boundaries } \\
\text { Extension Acts. }\end{array}$ & $\begin{array}{l}\text { of lands and resources, and the } \\
\text { relationship of federal, } \\
\text { provincial and Nisga'a laws, } \\
\text { within the Nass Area. }\end{array}$ & $\begin{array}{l}\text { the Tlicho relating to land, } \\
\text { resources and self-government. }\end{array}$ \\
\hline $\begin{array}{l}\text { The First Nation undertakes } \\
\text { that it will not exercise any } \\
\text { rights or authority it may have } \\
\text { other than in accordance with } \\
\text { the terms of the treaty. }\end{array}$ & $\begin{array}{l}\text { In consideration of the rights } \\
\text { and benefits herein set forth in } \\
\text { favour of the James Bay Cree } \\
\text { and Inuit of Quebec hereby } \\
\text { cede, release, surrender, and } \\
\text { convey all their Native claims, } \\
\text { rights, titles and interest...to } \\
\text { land in the Territory and in } \\
\text { Quebec. }\end{array}$ & & $\begin{array}{l}\text { Except as provided in s.2.6.1, } \\
\text { the Tlicho will not exercise or } \\
\text { assert any Aboriginal or treaty } \\
\text { rights, other than: } \\
\text { (a)any rights set out in the } \\
\text { Agreement; or } \\
\text { (b)the Treaty } 11 \text { rights } \\
\text { respecting annual payments to } \\
\text { the Indians and payments of the } \\
\text { salaries of teachers to instruct } \\
\text { the children of the Indians. }\end{array}$ \\
\hline \multicolumn{4}{|c|}{ MUTUAL ASSURANCES AND STATEMENTS } \\
\hline $\begin{array}{l}\text { Assurance that the parties will } \\
\text { only exercise rights respecting } \\
\text { the ownership or use of lands } \\
\text { or resources in accordance with } \\
\text { the terms of the treaty. }\end{array}$ & $\begin{array}{l}\text {..this Agreement shall } \\
\text { extinguish all Native claims, } \\
\text { rights, title and interest of all } \\
\text { Indians and all Inuit in and to } \\
\text { the Territory and the native } \\
\text { claims, rights, title.... whatever } \\
\text { they may be. }\end{array}$ & $\begin{array}{l}\text { This Agreement is binding on } \\
\text { the Parties. } \\
\text { The Parties are entitled to rely } \\
\text { on this Agreement. } \\
\text { This Agreement constitutes the } \\
\text { full and final settlement in } \\
\text { respect of the all aboriginal } \\
\text { rights, including aboriginal } \\
\text { title, in Canada of the Nisga'a } \\
\text { Nation. }\end{array}$ & $\begin{array}{l}\text { The Tlicho Agreement contains } \\
\text { a non-assertion clause (noted } \\
\text { above) but is also contains a } \\
\text { back up release which reads: } \\
\text { If } 2.6 .1 \text { or } 2.6 .2 \text { is not } \\
\text { enforceable in relation to a land } \\
\text { right, and that } \\
\text { (a)results in the imposition on } \\
\text { government or any person of } \\
\text { any obligations, related to } \\
\text { that right, to the Tlicho or } \\
\text { any person who is not to } \\
\text { exercise or assert it; } \\
\text { (b)affects the ability of Tlicho }\end{array}$ \\
\hline
\end{tabular}




\begin{tabular}{|c|c|c|c|}
\hline 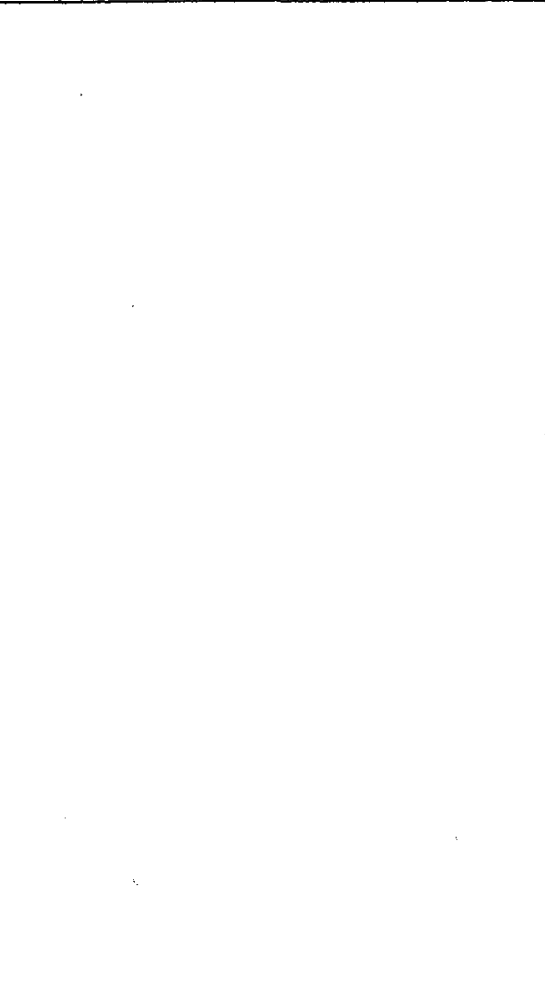 & & & $\begin{array}{l}\text { Citizen, the Tlicho First } \\
\text { Nation or the Tlicho } \\
\text { Government to exercise and } \\
\text { enjoy all their rights, } \\
\text { authorities, jurisdiction and } \\
\text { privileges that are set out in } \\
\text { the Agreement; or } \\
\text { (c) affects the ability of any } \\
\text { other person or government } \\
\text { to exercise and enjoy all the } \\
\text { rights, authorities, } \\
\text { jurisdictions and privileges } \\
\text { they would have if that } \\
\text { right did not continue to } \\
\text { exist, } \\
\text { the Tlicho cede, release and } \\
\text { surrender, as of the effective } \\
\text { date, that land right to the } \\
\text { extent required to achieve the } \\
\text { purpose in } 2.6 .4 \text {. }\end{array}$ \\
\hline \multicolumn{4}{|c|}{ LANDS } \\
\hline $\begin{array}{l}\text { Settlement Land }{ }^{1} \text { will be } \\
\text { subject to the rights of the } \\
\text { Government, third parties and } \\
\text { the public that are set out in the } \\
\text { treaty. Any and all other rights } \\
\text { belong to the Aboriginal group. }\end{array}$ & $\begin{array}{l}\text { Category I lands are lands set } \\
\text { aside for the exclusive use and } \\
\text { benefit of the respective James } \\
\text { Bay Cree and Inuit of } \\
\text { Quebec...under the } \\
\text { administration and control of } \\
\text { Canada, subject to the terms }\end{array}$ & $\begin{array}{l}\text { Category A lands fall under } \\
\text { "full" fee simple ownership, the } \\
\text { Nisga' a nation can sell, lease or } \\
\text { grant a right of way to the land, } \\
\text { and own all mineral and forest } \\
\text { resources. }\end{array}$ & $\begin{array}{l}\text { Referenced as geographical } \\
\text { areas. } \\
\text { The first area, the Monfwi } \\
\text { Gogha De Niitlee, is the largest } \\
\text { of the four areas and embodies } \\
\text { all the Tlicho communities. } \\
\text { Under the agreement, the }\end{array}$ \\
\hline
\end{tabular}

Hamilton defines settlement land as "the portion of land within the Treaty Area that is owned by the Aboriginal party". Hamilton, supra note 4 at 103. 


\begin{tabular}{|c|c|c|c|}
\hline & $\begin{array}{l}\text { and conditions of the } \\
\text { Agreement }\end{array}$ & & $\begin{array}{l}\text { Tlicho will exercise most of } \\
\text { their rights within the Monfwi } \\
\text { Gogha De Niitlee, including } \\
\text { year round harvesting rights. }\end{array}$ \\
\hline \multirow[t]{3}{*}{$\begin{array}{l}\text { Non-Settlement Land }{ }^{2} \text { will be } \\
\text { subject to the rights of the } \\
\text { Aboriginal party that are set out } \\
\text { in the treaty. Any and all other } \\
\text { rights belong to the } \\
\text { Government, third party or } \\
\text { private owners of land. }\end{array}$} & $\begin{array}{l}\text { Category II lands are identified } \\
\text { as those lands that the Cree and } \\
\text { Inuit people have exclusive } \\
\text { hunting, fishing and trapping } \\
\text { rights yet do not have a right to } \\
\text { occupancy. }\end{array}$ & $\begin{array}{l}\text { Category B Lands are the } \\
\text { parcels of land outside Nisga'a } \\
\text { Lands }\end{array}$ & $\begin{array}{l}\text { The second, known as } \\
\text { Wekeezhii, is a resource } \\
\text { management area which is } \\
\text { bordered by the Sahtu and } \\
\text { Gwich'in Land claim } \\
\text { settlement areas }\end{array}$ \\
\hline & $\begin{array}{l}\text { Category III, is designated as } \\
\text { lands for public use and falls } \\
\text { within the appropriate } \\
\text { provincial provisions. }\end{array}$ & & $\begin{array}{l}\text { Third area, is known as the } \\
\text { Tlicho Lands. The Tlicho } \\
\text { Government, on behalf of the } \\
\text { Tlicho citizens, holds fee } \\
\text { simple title to approximately } \\
3 \% \text { of the Tlicho land within } \\
\text { the settlement areas. Like with } \\
\text { the Nisga'a Nation, the Tlicho } \\
\text { can sell, lease or grant a right } \\
\text { of way to the land, and own all } \\
\text { mineral forest rights on Tlicho } \\
\text { lands. }\end{array}$ \\
\hline & & & $\begin{array}{l}\text { The fourth area is called } \\
\text { Ezodziti. This area is not } \\
\text { owned by the Tlicho and nor do } \\
\text { hunting and harvesting rights }\end{array}$ \\
\hline
\end{tabular}

2 Hamilton defines non-settlement land as "the rest of the land within the Treaty Area that is owned by the Government or is privately owned and in which (the Aboriginal party) has special rights". Ibid. 


\begin{tabular}{|c|c|c|c|}
\hline & & & $\begin{array}{l}\text { exist within this area but it is } \\
\text { protected due to historical and } \\
\text { cultural importance, to the } \\
\text { Tlicho Nation and all } \\
\text { Canadians. }\end{array}$ \\
\hline \multicolumn{4}{|c|}{ DISPUTE RESOLUTION MECHANISMS AND JUDICIAL REVIEW } \\
\hline $\begin{array}{l}\text { Key Elements of Dispute } \\
\text { Resolution Clause; } \\
\text { 1. A range of techniques for } \\
\text { resolving disputes. } \\
\text { 2. Method for selecting } \\
\text { mediator. } \\
\text { 3. Method for selecting } \\
\text { arbitrator. } \\
\text { 4. Alternative options. } \\
\text { 5. Clause that states all } \\
\text { matters of dispute arising } \\
\text { from the treaty should be } \\
\text { required to be resolved } \\
\text { through the dispute } \\
\text { resolution process } \\
\text { (including treaty } \\
\text { interpretation) } \\
\text { Judicial Review process should } \\
\text { be included. }\end{array}$ & None & $\begin{array}{l}\text { Chapter } 19 \\
\text { Includes: } \\
\text { Definition, scope, stages, } \\
\text { negotiating conditions, } \\
\text { (collaborative negotiations, } \\
\text { facilitated process, arbitration } \\
\text { and judicial review) settlement } \\
\text { agreement, application of } \\
\text { legislation, where it can be } \\
\text { invoked and costs. }\end{array}$ & $\begin{array}{l}\text { Chapter } 6 \\
\text { Includes: } \\
\text { Definition, scope, negotiating } \\
\text { conditions, (DR administration, } \\
\text { mediation and arbitration) } \\
\text { settlement agreement, } \\
\text { application of legislation, and } \\
\text { costs, etc. } \\
\text { No mention of Judicial Review } \\
\text { process. }\end{array}$ \\
\hline \multicolumn{4}{|c|}{ AMENDMENT PROCESS } \\
\hline $\begin{array}{l}\text { Amendment Process whereby } \\
\text { the parties can, if they agree, } \\
\text { amend certain provisions of the } \\
\text { treaty to respond to changing } \\
\text { circumstances. }\end{array}$ & None & Includes amendment process & Includes amendment process \\
\hline
\end{tabular}


APPENDIX 6

\begin{tabular}{|l|l|l|}
\hline \multicolumn{2}{|c|}{ COMPARISON TABLE } \\
\hline 1 & HAMILTON'S MODEL & RECONCILIATION MODEL \\
\hline 2 & $\begin{array}{l}\text { Recognition of Aboriginal } \\
\text { Rights/Title }\end{array}$ & $\begin{array}{l}\text { Fe Surrender } \\
\text { acknowledge that Aboriginal rights and } \\
\text { title exist throughout Canada and through } \\
\text { the process of negotiation the extent of } \\
\text { these rights and title will be explored. }\end{array}$ \\
\hline 3 & $\begin{array}{l}\text { All parties including governments } \\
\text { and third party rights included in } \\
\text { treaty }\end{array}$ & $\begin{array}{l}\text { Focus of treaty should be on Aboriginal } \\
\text { rights/title }\end{array}$ \\
\hline 4 & $\begin{array}{l}\text { Treaty fair and balanced so all } \\
\text { commitments are jointly made }\end{array}$ & $\begin{array}{l}\text { Treaty fair and balanced so all } \\
\text { commitments are jointly made }\end{array}$ \\
\hline 5 & $\begin{array}{l}\text { Guarantee the enforceability of the } \\
\text { treaty - Dispute Resolution } \\
\text { Mechanism }\end{array}$ & $\begin{array}{l}\text { Guarantee the enforceability of the treaty } \\
\text { - Dispute Resolution Mechanism }\end{array}$ \\
\hline 6 & $\begin{array}{l}\text { Treaty forms the basis for future } \\
\text { relationships based on mutual } \\
\text { respect and trust }\end{array}$ & $\begin{array}{l}\text { Tands held in fee simple. } \\
\text { future relationships between Aboriginal } \\
\text { beneficiaries, the federal } \\
\text { provincial/territorial governments, third } \\
\text { parties and all Canadian citizens. }\end{array}$ \\
\hline 8 & $\begin{array}{l}\text { Accommodation } \\
\text { Allows for lands to be held in fee simple } \\
\text { or shared-use policy which preserves title } \\
\text { of both the Crown and Aboriginal people } \\
\text { to alleviate concerns that settlement areas } \\
\text { will become reserves. }\end{array}$ \\
\hline
\end{tabular}

